\title{
FERTILIZAÇÃO DE POVOAMENTOS DE EUCALIPTO COM O BIOSSÓLIDO DA ETE-DE BARUERI, SP: DEMANDA POTENCIAL E NÍVEL MÍNIMO DE RESPOSTA
}

\section{LUIZ CARLOS DE FARIA}

Engenheiro Florestal

Orientador: Prof. Dr. LUIZ CARLOS ESTRAVIZ RODRIGUEZ

Dissertação apresentada à Escola Superior de Agricultura "Luiz de Queiroz", Universidade de São Paulo, para obtenção do título de Mestre em Ciências, Área de Concentração: Ciências Florestais.

PIRACICABA

Estado de São Paulo - Brasil

Setembro -2000 


\section{ERRATA}

No último parágrafo da página 13 , onde se lê "... para absorver o excedente da demanda; e (iii) para a disposição de cinzas de incineração ....", leia-se "... para absorver o excedente da oferta; e (iii) para a disposição de cinzas de incineração que apresentarem altos níveis de contaminantes; ...".

No último parágrafo da página 22, onde se lê " A Taenia sp., por exemplo, pode sobreviver em solos tratados com biossólido por mais de um ano (Kempton \& Cusack, 1999).", leia-se " A Taenia sp., por exemplo, pode sobreviver por mais de um ano em solos tratados com biossólido (Kempton \& Cusack, 1999)." 
Dados Internacionais de Catalogação na Publicação (CIP) DIVISĀO DE BIBLIOTECA E DOCUMENTAÇĀO - Campus "Luiz de Oueiroz"/USP

Faria, Luiz Carlos de

Fertilização de povoamentos de eucalipto com o biossólido da ETE de Banueri, SP : demanda potencial e nivel minimo de resposta / Luiz Carlos de Faria. - - Piracicaba, 2000.

85 p. : il.

Dissertação (mestrado) - Escola Superior de Agricultura Luiz de Queiroz, 2000. Bibliografia.

1. Adubo orgânico 2. Eucalipto 3. Lodo de esgoto 4. Povoamento florestal I. Titulo

CDD 634.9734

"Permitida a cópia total ou parcial deste documento, desde que citada a fonte - $\mathbf{O}$ autor" 
Dedico este trabalho a minha esposa, Sandra e minha filha, Tayná;

a meus pais, Antônio e Maria de Lourdes;

aos meus irmãos, Toninho, Terezinha, Zé, Cristina, Marcelo, Fernando e a seus familiares. 


\section{AGRADECIMENTOS}

Ao professor Luiz Carlos Estraviz Rodriguez, pela orientação e amizade.

À CAPES, pela concessão da bolsa de mestrado.

Ao IPEF'e SABESP pela oportunidade de realização do trabalho.

Ao Departamento de Ciências Florestais da ESALQ/USP, pela oportunidade da realização do mestrado.

Ao Instituto Florestal de São Paulo, pela disponibilização de dados utilizados no trabalho, em especial ao: Kronka, Marco Nalon, Ciro e Geraldo.

À Cia. SUZANO de Papel e Celulose, em especial ao Engenheiro Florestal Danilo, pela disponibilização de dados utilizados na dissertação.

Aos amigos do LMQ: Fábio, Fabiano, Gnomo, Paulão, Beija-flor, Flaviana e Mário.

Aos amigos do Departamento de Ciências Florestais e IPEF: Jefferson, Rogério, Zé Martins, Dirceu, Ivo e Erivelton.

Ao amigo Marcelino, sua esposa Claudia e seu filho (e meu afilhado) Miguel.

Aos amigos Alberto (Tora), Maurício (xixo).

Ao pessoal do projeto SABESP: Maria Emília, Fábio Poggiani, Leonardo, Vanderlei e Cristiano.

A Luciano Mendez Vaz (Baiano), grande amigo e companheiro.

A Maria Antonieta e Charles, pelo incentivo e apoio. 


\section{SUMÁRIO}

Página

LISTA DE FIGURAS $\ldots \ldots \ldots \ldots \ldots \ldots \ldots \ldots \ldots \ldots \ldots \ldots \ldots \ldots \ldots \ldots \ldots \ldots$

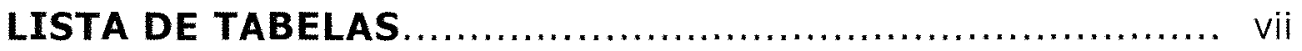

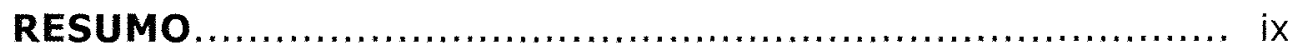

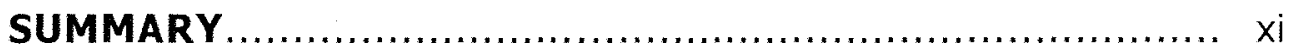

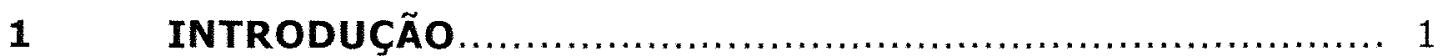

$1.1 \quad$ Objetivos e hipóteses.......................................... 2

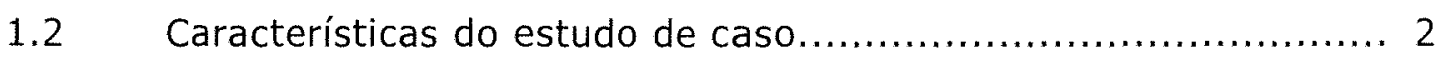

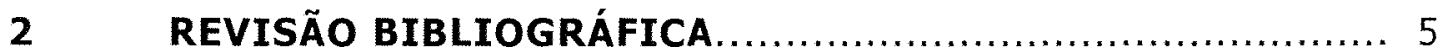

2.1 Geração de biossólido nas ETEs.................................. 5

2.2 Alternativas para a destinação final do biossólido................. 9

2.2.1 Alternativas não convencionais................................... 9

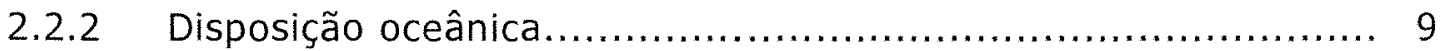

2.2 .3 Incineração...................................................... 10

2.2.4 Recuperação de áreas degradadas................................. 11

2.2.5 Landfarming ("Fazenda de Lodo") ............................... 11

2.2.6 Disposição em aterros sanitários................................. 12

2.3 Uso de biossólido e outros residuos orgânicos como fertilizante......................................................... 14

2.3.1 Possíveis contaminantes encontrados no biossólido............... 16

2.3.1.1 Elementos químicos e orgânicos perigosos.......................... 16

2.3.1.2 Organismos patogênicos........................................ 22

2.3.2 Aspectos legais............................................... 23

2.3.3 Fertilização orgânica de povoamentos florestais: aspectos silviculturais e econômicos...................................... 33

2.4 Estratégias de manejo do biossólido para uso como fertilizante..................................................... 39

2.5 Determinação dos níveis economicamente ótimos de fertilização........................................................... 4 
2.6 Matemática financeira............................................ 44

2.7 Critérios de avaliação financeira ................................... 45

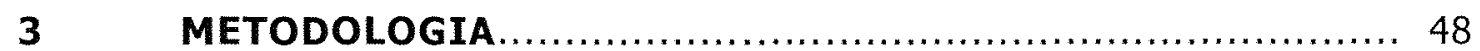

3.1 Demanda potencial de biossólido em povoamentos de eucaliptos no entorno da ETE de Barueri..................................... 48

3.1.1 Levantamento da área de eucaliptos no entorno da ETE de Barueri........................................................... 48

3.1.2 Seleção da área potencialmente disponível anualmente para fertilização com biossólido............................................ 49

3.2 Produção mínima de madeira para viabilização econômica da fertilização de eucaliptos com biossólido............................ 50

3.2.1 Curva de resposta à aplicação de biossólido........................ 51

3.2.1.1 Desenvolvimento das expressões para calculo do NMR............ 52

3.2.2 Custos associados ao uso do biossólido como fertilizante......... 55

3.3 Taxa máxima de aplicação de biossólido nos povoamentos florestais........................................................... 56

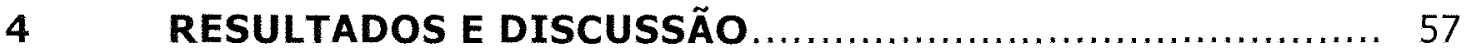

4.1 Demanda potencial de biossólido em povoamentos de eucalipto no entorno da ETE de Barueri..................................... 57

4.2 Custos da disposição de biossólido em povoamentos de eucalipto........................................................... 62

4.3 Nível Mínimo de Resposta (NMR) para aplicação do biossólido em povoamentos de eucalipto ...................................... 65

5 CONSIDERAÇõES FINAIS E CONCLUSÕES .................... 73

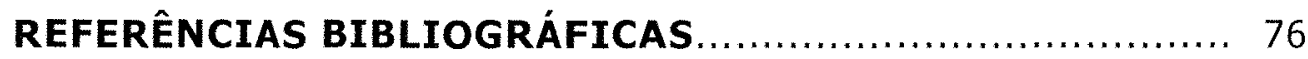

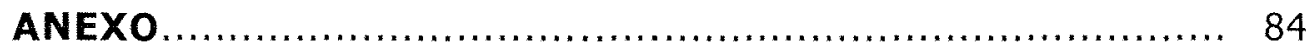




\section{LISTA DE FIGURAS}

Figura

Página

1 Posição relativa do Município de Barueri onde está localizada a ETE da SABESP, e do Município de Itatinga onde se localiza o experimento com o biossólido aplicado em Eucalyptus grandis. ......................... 3

2 Estimativa da produção diária de biossólido na ETE de Barueri. ........ 8

3 Evolução da área reflorestada anualmente no Brasil com espécies de eucalipto.

4 Representação esquemática da metodologia para diagnóstico do potencial de uso do biossólido da ETE de Barueri em povoamentos de eucalipto do Estado de São Paulo.

5 Evolução do custo de frete para calcário à granel em função da distância de transporte.

6 Variação do custo total da fertilização de eucaliptos com biossólido, por tonelada seca aplicada, em função da distância de transporte, considerando teor de umidade de $60 \%$.

7 NMR por tonelada seca de biossólido aplicada em povoamentos de eucalipto em função da distância de transporte, da taxa de juros e do preço de madeira, considerando teor de umidade no biossólido de $60 \%$. É valido para o cenário de aplicação no plantio e ciclo de 7 anos e para a aplicação no plantio e reaplicação na condução da brotação com rotações de 7 anos.

8 NMR por tonelada seca de biossólido aplicada em função da distância de transporte, da taxa de juros e do preço de madeira, considerando teor de umidade no biossólido de $60 \%$. É valido para o cenário de aplicação apenas no plantio e ciclo de 14 anos com duas rotações de 7 anos.

9 NMR por tonelada seca de biossólido aplicada em função da distância de transporte, da taxa de juros e do preço de madeira, considerando teor de umidade no biossólido de $60 \%$. É valido para o cenário de aplicação apenas no plantio e ciclo de 21 anos com três rotações de 7 anos.

10 NMRs para dois teores de umidade no biossólido comparativamente aos ganhos de produtividade, por tonelada aplica e em relação a testemunha, da fertilização de Eucalyptus grandis com cinza de biomassa florestal (CBF) e composto de resíduos urbanos (CRU). 


\section{LISTA DE TABELAS}

Tabela

Página

1 Produção de biossólido e custos de implantação de alguns sistemas de tratamento de esgotos.

2 Limites para a concentração de contaminantes no biossólido para a sua co-disposição com resíduos sólidos urbanos em aterros sanitários. 12

3 Composição média de amostras de esterco de animais e de biossólido. 15

4 Nitrogênio disponível em diferentes tipos de biossólido após um ano de aplicação solo. .......................................................... 19

5 Valores máximos permissíveis para componentes orgânicos da água potável.

6 Concentração máximas de elementos químicos no biossólido para seu uso como fertilizante em diversos locais do mundo.

7 Densidades máximas de patógenos nos dois tipos de biossólido que podem ser aplicados em áreas agrícolas, segundo o Manual Técnico da CETESB (P 4.230 - jan./99).

8 Limites das concentrações de poluentes químicos regulados pelo Manual Técnico da CETESB (P 4.230 - jan./99) para aplicação de biossólido em áreas agrícolas.

9 Densidades de alguns microrganismos encontrados em amostras de biossólido da ETE de Barueri.

10 Concentrações médias e desvios padrão de alguns metais presentes em amostras de biossólido da ETE de Barueri.

11 Concentração de metais pesados não nutrientes em diferentes tipos de fertilizantes minerais.

12 Concentração de alguns metais em amostras de biossólido da ETE de Barueri.

13 Caracterização química média de alguns resíduos utilizados em experimentos de fertilização de povoamentos de eucalipto.

14 Exemplos de doses de biossólido utilizadas em experimentos de fertilização com espécies florestais.

15 Área reflorestada com eucaliptos a diferentes raios de distância tendo como centro a ETE de Barueri.

16 Área de eucalipto disponível anualmente para a disposição do biossólido a diferentes raios de distância da ETE de Barueri. 
17 Concentração de algumas formas nitrogenadas em amostras de biossólido da ETE de Barueri. ............................................. 59

18 Demanda potencial de biossólido em povoamentos de eucalipto considerando diferentes produções de biossólido na ETE de Barueri, doses de aplicação no campo e percentuais de redução na área disponivel anualmente.

19 Resultados estatísticos para o ajuste do modelo linearizado: custo de frete em função da distância de transporte. 


\section{FERTILIZAÇÃo DE POVOAMENTOS DE EUCALIPTO COM O BIOSSÓLIDO DA ETE DE BARUERI, SP: DEMANDA POTENCIAL E NÍVEL MÍNIMO DE RESPOSTA}

Autor: LUIZ CARLOS DE FARIA

Orientador: Prof. Dr. LUIZ CARLOS ESTRAVIZ RODRIGUEZ

\section{RESUMO}

O lodo de esgoto ou biossólido, como recentemente vem sendo denominado, é o principal resíduo produzido nas Estações de Tratamento de Esgoto (ETEs), cuja destinação final tem despertado a atenção de diversos órgãos governamentais e instituições de pesquisa. Um dos principais problemas enfrentados pelos pesquisadores é encontrar um destino final ambientalmente adequado e economicamente viável ao grande volume de biossólido que será produzido no futuro. Dentre as propostas, sua utilização como fertilizante orgânico e/ou condicionador de solos em sítios florestais é apontada pelos pesquisadores como uma alternativa promissora. Neste contexto, este trabalho tem como objetivos: (i) apresentar uma estimativa da demanda potencial por biossólido, produzido na ETE de Barueri, em povoamentos de eucalipto do seu entorno, dentro do Estado de São Paulo; e (ii) determinar as produções mínimas de madeira que justificam economicamente o uso do biossólido como fertilizante em povoamentos de eucalipto, considerando diferentes taxas de juros, preços de madeira e distâncias de transporte. A demanda potencial foi determinada utilizando técnicas de Sistemas de Informações Geográficas (SIG) e dados digitais do último inventário florestal do Estado de São Paulo, publicado pelo Instituto Florestal de São Paulo em 1993. A análise econômica utiliza o parâmetro de decisão "Nível Mínimo de Resposta (NMR)", desenvolvido com o auxílio de fórmulas de matemática financeira. O estudo da demanda potencial demostrou que o intervalo de variação no raio de consumo do biossólido, em torno da ETE de Barueri, em povoamentos de eucalipto varia de 15 a $178 \mathrm{~km}$. Essas 
distâncias refletem a combinação de níveis de produção de 150 e 350 t dia $^{-1}$ e doses de biossólido de 10 e $30 \mathrm{t} \mathrm{ha}^{-1}$, ambos em base seca. O estudo econômico demonstrou que a fertilização de povoamentos de eucalipto com biossólido contendo altos teores de umidade (60\%) pode apresentar sérias limitações econômicas. Mesmo nos cenários mais favoráveis (taxa mínima aceitável de retorno de $6 \%$ e preço de $\mathrm{R} \$ 10,00 \mathrm{st}^{-1}$ para a madeira), ganhos de produtividade, por tonelada seca aplicada, acima de 5 st ha $^{-1}$ são necessários para justificar economicamente a aplicação em distâncias longas de transporte $(\geq 100 \mathrm{~km}$ ). Nos cenários mais desfavoráveis (taxa de $12 \%$ e preço da madeira de $R \$ 7,00 \mathrm{st}^{-1}$ ), a fertilização de florestas com biossólido foi limitada à situações que resultam em ganhos de produtividade, por tonelada seca aplicada, de até 10,92 st ha $^{-1}$ em locais próximos $(\leq 100 \mathrm{~km}$ ) da ETE. O principal fator para esse comportamento é o elevado custo com o transporte, devido principalmente a elevada taxa de umidade do biossólido (em média 60\%). São conclusões deste trabalho: (i) que existem povoamentos de eucalipto no entorno de Barueri, suficientes para consumir toda a produção de biossólido dessa ETE em distâncias de transporte economicamente viáveis, quando considerados cenários favoráveis financeiramente; e (ii) que existem cenários que viabilizariam o uso do biossólido em povoamentos de eucalipto dentro de intervalos realísticos de taxas de juros e preços de madeira, o que justifica estudos mais detalhados dessa alternativa de destinação final para o biossólido, em termos silviculturais e ecológicos. 


\title{
FERTILIZATION OF EUCALYPTUS STANDS WITH BIOSOLID PRODUCED IN BARUERI WTP: POTENTIAL DEMAND AND MINIMUM LEVEL OF PRODUCTIVITY
}

\author{
Author: LUIZ CARLOS DE FARIA \\ Adviser: Prof. Dr. LUIZ CARLOS ESTRAVIZ RODRIGUEZ
}

\section{SUMMARY}

The sewage sludge or biosolid, a more recent denomination, is the main waste produced in Wastewater Treatment Plants (WTPs). It's final destination called the attention of several governmental agencies and research institutions. One of the main problems faced by the researchers is to find an ambiently appropriate and economically viable destiny to the large amount of biosolid that will be produced in the future. One of the potential alternatives is its use as organic fertilizer and/or soil conditioner in forest plantations. In this context, this work has two main objectives: (i) to estimate the potential demand for biosolid by eucalyptus palntations, surrounding the Barueri WTP in the State of São Paulo, Brazil and (ii) to determine the minimum production increment to justify economically the use of biosolid as fertilizer in these plantations, considering different interest rates, wood prices and transportation distances. The potential demand was determined using Geographical Information Systems (GIS) techniques and digital data of the last State of São Paulo Forest Inventory, published by the Forest Institute of São Paulo in 1993. The economical analysis developed a decision parameter called "Minimum Productivity Level (MPL)", based on interest formulas. The potential demand study shows that the consumption for the Barueri WTP's biosolid in eucalyptus plantation varies from 15 to $178 \mathrm{~km}$. These distances reflect the combination of production levels varying from 150 to 350 ton day ${ }^{-1}$ and application rates range from 10 to 30 ton ha ${ }^{-1}$, both in dry basis. The economic study demonstrated that the biosolid fertilization with high humidity level 
$(60 \%)$ can present serious limitations. Even in the most favorable scenario (minimum acceptable rate of $6 \%$ and a $R \$ 10,00 \mathrm{st}^{-1}$ price for the wood) increments of 5 st ha ${ }^{-1}$, per dry ton, would be necessary to justify economically application in long transportation distances $(\geq 100 \mathrm{~km})$. In the most unfavorable scenario (rate of $12 \%$ and a $R \$ 7,00 \mathrm{st}^{-1}$ price for the wood), the biosolid fertilization is limited to situations where increments of $10,92 \mathrm{st} \mathrm{ha}^{-1}$ per dry ton can be achieved considering short transportation distances $(\leq 100 \mathrm{~km})$. The high transportation costs is the main factor for this results, due mainly to the high humidity level of the biosolid (60\% in average). The conclusions are: (i) there are sufficient eucalyptus plantations surrounding the Barueri WTP to consume all the biosolid produced in the plant; and (ii) some realistic interest rates and wood prices make possible the use of biosolid as a organic fertilizer for these plantations. The results justify detailed silvicultural and ecological studies for this alternative as a final destination for the biosolid produced in WTPs. 


\section{INTRODUÇÃO}

O grande crescimento populacional verificado nas últimas décadas nos centros urbanos, associado a elevados padrões de produção e consumo, têm aumentado de forma preocupante a quantidade e a variedade de resíduos produzidos. Os resíduos produzidos à partir do tratamento de águas residuárias $^{1}$ nas Estações de Tratamento de Esgoto (ETES) têm se transformado em um problema nos grandes centros urbanos onde são gerados. O lodo de esgoto ou biossólido, como recentemente vem sendo denominado, é o principal resíduo produzido nas ETEs, cuja destinação final tem despertado a atenção de diversos órgãos governamentais e instituições de pesquisa. Um dos principais problemas enfrentado pelos pesquisadores é encontrar um destino final ambientalmente adequado e economicamente viável ao grande volume de biossólido que será produzido no futuro. Diversas alternativas vêm sendo estudadas. Dentre as propostas, seu uso como fertilizante orgânico e/ou condicionador de solos em sítios florestais é apontada por diversos autores como uma alternativa promissora. Entretanto, essa proposta oferece duas questôes básicas que são abordadas neste trabalho, e que se referem: (i) à demanda por biossólido nos povoamentos florestais no entorno das ETEs e (ii) à viabilidade econômica da disposição do biossólido nos sítios florestais. Este trabalho analisa um estudo de caso envolvendo a ETE de Barueri e os povoamentos de eucalipto no seu entorno, dentro do Estado de São Paulo.

\footnotetext{
${ }^{1}$ Qualquer despejo ou resíduo líquido, de origem doméstica ou industrial, com potencialidade de causar poluição.
} 


\subsection{Objetivos e hipóteses}

São objetivos deste trabalho:

a) Apresentar uma estimativa da demanda potencial por biossólido, produzido na ETE de Barueri, em povoamentos de eucalipto no seu entorno, dentro do Estado de São Paulo.

b) Determinar as produções mínimas de madeira que justificam economicamente o uso do biossólido como fertilizante em povoamentos de eucalipto, considerando diferentes taxas de juros, preços de madeira e distâncias de transporte.

Associados com cada objetivo definem-se duas hipóteses de trabalho, para as quais procuram-se evidências para corroborá-las ou não. As hipóteses são as seguintes:

a) Existem áreas com povoamentos de eucalipto potencialmente disponíveis para a disposição do biossólido produzido pela ETE de Barueri dentro de raios de distância economicamente viáveis.

b) Justifica-se economicamente o uso do biossólido como fertilizante em plantios de eucalipto para certos níveis de preço de madeira, taxas de juros e distâncias de transporte.

\subsection{Características do estudo de caso}

O presente trabalho é parte de um projeto multi-disciplinar que avalia a aplicação de biossólidos residuais do tratamento de esgoto em povoamentos florestais. O projeto é fruto de um convênio firmado entre o Instituto de Pesquisas e Estudos Florestais (IPEF), Escola Superior de Agricultura "Luiz de Queiroz" da Universidade de São Paulo (ESALQ/USP) e a Companhia de Saneamento Básico do Estado de São Paulo (SABESP), O objetivo geral do 
Posição relativa dos municípios que compõem a Região Metropolitana de São Paulo (RMSP)

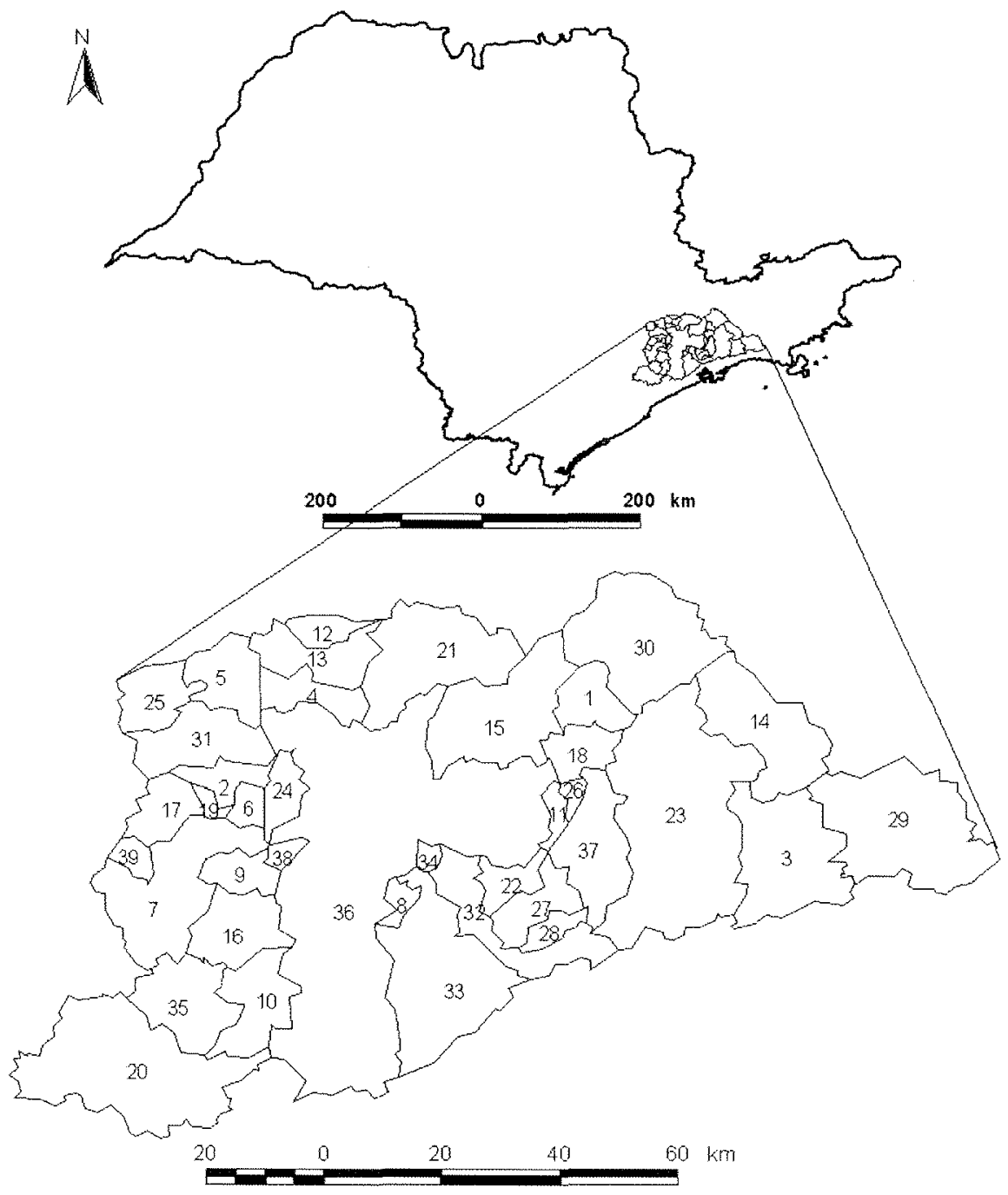

LEGENDA:

1. Arujá

5. Cajamar

9. Embú

13. Franco da Rocha

17. Itapeví

21. Mairiporã

25. Pirapora do Bom Jesus

29. Salesópolis

33. S. Bernardo do Campo

37. Suzano

2. Barueri

6. Carapicuíba

10. Embú Guaçu

14. Guaracema

18. Itaquatecetuba

22. Mauá

26. Poá

30. Santa Izabel

34. S. Caetano do Sul

38. Taboão da Serra
3. Biritiba Mirim

7. Cotia

11. Ferraz Vasconcelos

15. Guarulhos

19. Jandira

23. Mogi das Cruzes

27. Ribeirão Pires

31. Santana de Parnaíba

35. S. Lourenço da Serra

39. Vargem Grande Paulista
4. Caieiras

8. Diadema

12. Francisco Morato

16. Itapecirica da Serra

20. Juquitiba

24. Osasco

28. Rio Grande da Serra

32. Santo André

36. São Paulo 
em base seca (Tsutya, 2000). A atual destinação final desse volume de biossólido é a sua co-disposição com resíduos urbanos (lixo) em um aterro sanitário localizado as margens da Rodovia do Bandeirantes. Neste caso específico, há um acordo em que o Departamento de Limpeza Urbana de São Paulo (LIMPURB) permite a disposição do biossólido e, em troca, a SABESP se compromete a tratar o chorume ${ }^{2}$ que é gerado no aterro pela decomposição dos resíduos ali depositados. A SABESP arca apenas com o custo de transporte do biossólido até o aterro, cuja vida útil prevista chega ao fim no ano de 2001 (Departamento de Limpeza Urbana de São Paulo, s.d.).

${ }^{2}$ Líquido, proveniente da decomposição do lixo, com alto potencial poluente. 


\section{REVISÃo BIBLIOGRÁFICA}

A revisão bibliográfica aqui apresentada aborda o tema biossólido de forma abrangente. Trata da sua geração nas ETEs e das principais alternativas para a sua destinação final, suas potencialidades e limitações e os aspectos legais inerentes ao assunto. Também é abordado nesta parte do trabalho o uso de biossólido e outros resíduos orgânicos na área florestal, seus aspectos ecológicos, silviculturais e econômicos.

\subsection{Geração de biossólido nas ETEs}

O volume de biossólido produzido e as estimativas de produções futuras são aspectos que devem ser considerados no diagnóstico do potencial de uso desse resíduo em povoamentos florestais. Se o biossólido for utilizado para a fertilização de eucalipto, por exemplo, devem existir áreas com povoamentos dessas espécies suficientes para absorver não só a atual produção como também a futura, para que essa proposta de destinação seja viável a longo prazo.

O lodo de esgoto reciclável de forma benéfica ${ }^{3}$ é denominado biossólido. Esse termo se refere normalmente ao lodo que passou por algum processo de estabilização. Esta estratégia, recomendada pela Water Environmental Federation (WEF), órgão ambiental dos Estados Unidos da América (EUA), é parte de um esforço para que se minimize o preconceito ainda existente contra esse resíduo.

\footnotetext{
${ }^{3}$ Quando o uso não causa dano ou ameaça à saúde, ao bem estar e à segurança pública ou ao meio ambiente. Water Environmental Federation - WEF. http://www.wef.org.
} 
A origem do preconceito é basicamente cultural. Segundo Organização Mundial da Saúde (s.d.) e Wang (1997), o uso de fezes humanas na agricultura tem mantido a fertilidade do solo em muitos países da Ásia Oriental e do Pacífico Ocidental por mais de 4.000 anos. Essa forma de destinação representa a única opção em áreas onde não existem sistemas coletores de esgotos (Organização Mundial da Saúde, s.d.) Atualmente a tendência é usar o termo biossólido (como será referido no presente trabalho) em substituição ao lodo de esgoto.

Devido aos recentes investimentos em programas de saneamento em todo o Brasil, alcançando cifras de 9,5 bilhões de reais em 1996 (Ministério do Planejamento, Orçamento e Gestão, s.d.) observa-se um acentuado aumento no volume de biossólido gerado e uma conseqüente redução da capacidade de suporte dos atuais aterros sanitários usados para a sua destinação final. Em um estudo realizado pela Secretaria de Planejamento do governo brasileiro constatou-se que em 1996 apenas 30\% do esgoto produzido em cidades brasileiras eram coletados, sendo que apenas $8 \%$ recebiam algum tipo de tratamento (Luduvice, 1998). Segundo estimativas realizadas por Andreoli \& Pergorini (1998), a parcela da população que vive sem condições sanitárias adequadas representa um potencial de geração diária entre 25.000 a $35.000 \mathrm{~m}^{3}$ de lodo primário ( 3 a $7 \%$ de sólidos) e de 150.000 a $200.000 \mathrm{~m}^{3}$ de lodo secundário ( 0,5 a $20 \%$ de sólidos).

O lançamento de esgoto sem tratamento em lagoas, rios e oceanos ainda é uma prática comum no Brasil (Campos, 1994). Em 1991, cerca de 10 bilhões de litros de esgoto não tratado eram lançados nos rios brasileiros todos os dias (Andreoli \& Pergorini, 1998). A degradação desses aqüíferos pode ser total, dependendo da concentração de poluentes nos resíduos lançados. Neste contexto, a função de uma ETE é tratar os esgotos coletados, reduzindo a sua carga poluente de tal forma que o seu efluente não cause impactos negativos acentuados nos corpos de água onde são lançados. A construção de ETEs, entretanto, não necessariamente elimina o problema. Segundo Andreoli et al. (1999) não são raras as situações em que o biossólido produzido nas ETEs 
retorna para os corpos de água. Mesmo em países considerados desenvolvidos, como a Austrália, podem ser encontradas situações semelhantes (Polglase \& Myers, 1995). Essa prática condenável reflete a falta de planejamento ocorrida na construção dessas estações, que ignorou por completo o problema de destinação final do resíduo produzido.

De modo geral a produção de biossólido é maior quanto mais eficiente for o sistema (Andreoli et al., 1999). A eficiência no tratamento do esgoto urbano observada em diversos sistemas de tratamento é variável (Tabela 1).

Tabela 1. Produção de biossólido e custos de implantação de alguns sistemas de tratamento de esgotos.

\begin{tabular}{|c|c|c|}
\hline TIPO DE TRATAMENTO & $\begin{array}{l}\text { BIOSSÓLIDO } \\
\text { PRODUZIDO }\end{array}$ & $\begin{array}{l}\text { CUSTO ESTIMADO } \\
\text { DE IMPLANTAÇÃO }\end{array}$ \\
\hline & g SST hab ${ }^{-1}$ dia $^{-1}$ & $\mathrm{R} \$ \mathrm{hab}^{-1}$ \\
\hline $\begin{array}{l}\text { Reator UASB (sem tratamento } \\
\text { complementar) }\end{array}$ & 15 a 20 & 25 a 35 \\
\hline $\begin{array}{l}\text { Lagoas aeradas aeróbias seguidas de } \\
\text { lagoas de decantação }\end{array}$ & 15 a 25 & 50 a 70 \\
\hline Reator UASB seguido de lodos ativados & 22 a 30 & 50 a 100 \\
\hline $\begin{array}{l}\text { Reator UASB seguido de filtro } \\
\text { biológico de alta taxa }\end{array}$ & 25 a 30 & 50 a 80 \\
\hline $\begin{array}{l}\text { Reator UASB e filtro biológico aerado } \\
\text { submerso }\end{array}$ & 25 a 30 & 80 a 100 \\
\hline Lodos ativados (convencional) & 30 a 40 & 100 a 160 \\
\hline Filtro biológico (alta taxa) & 35 a 40 & 100 a 130 \\
\hline Lodos ativados (aeração prolongada) & 40 a 45 & 60 a 80 \\
\hline Lodos ativados (alta taxa) & 65 a 70 & 80 a 90 \\
\hline
\end{tabular}

Fonte: Adaptado de Alem Sobrinho (2000).

UASB: Segundo o autor, se refere à sigla inglesa para reatores anaeróbios de fluxo ascendente e mata de lodo.

SST: Sólidos Secos Totais.

Hab.: Habitante.

A Figura 2 apresenta a estimativa de produção de biossólido na ETE de Barueri, onde é utilizado o sistema de tratamento de lodos ativados convencionais. 
350

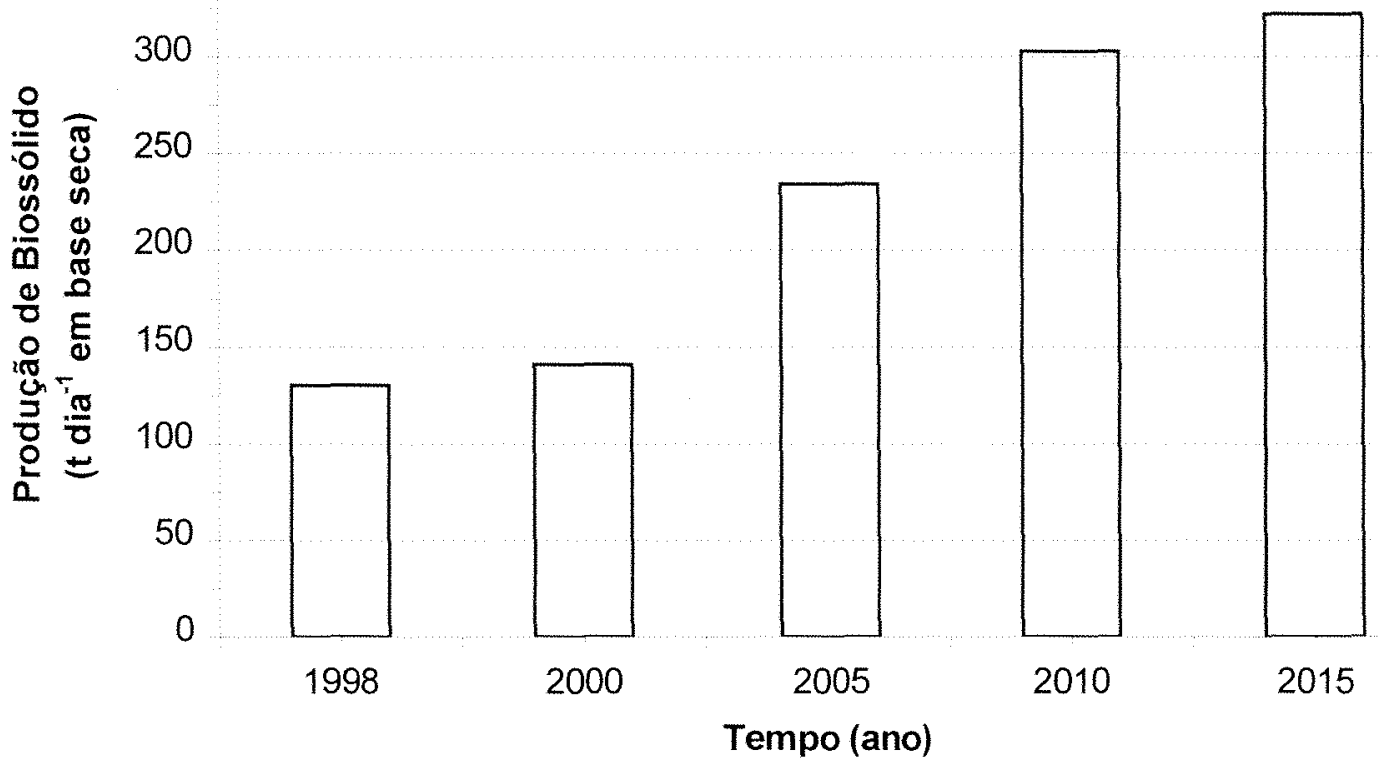

Figura 2 - Estimativa da produção diária de biossólido na ETE de Barueri. Fonte: Adaptado de Tsutya (2000).

A produção de biossólido na ETE de Barueri, que atualmente é de aproximadamente $140 \mathrm{t} \mathrm{dia}^{-1}$, em base seca, é estimada para o ano de $2015 \mathrm{em}$ 332 t dia ${ }^{-1}$, representando um aumento de $230 \%$ no período.

Segundo Miki (1998), no sistema de tratamento de lodos ativados convencionais utilizado na ETE de Barueri podem ser identificados três tipos de resíduos, de acordo com a fase do tratamento em que são analisados: (i) o primário: apresenta forte odor, alta concentração de patógenos e 1 a $6 \%$ de sólidos totais (4 a $10 \%$ se adensado); (ii) o secundário ou bruto que é obtido pela conversão biológica dos produtos voláteis do efluente primário; e (iii) o digerido resultante da estabilização biológica (em geral anaeróbia) do resíduo bruto (normalmente o termo biossólido se refere a este tipo de lodo). Kempton \& Cusack (1999) salientam que a principal vantagem da estabilização é a destruição de organismos patogênicos, redução do odor e prevenção à atração de vetores. 


\subsection{Alternativas para a destinação final do biossólido}

Diversas alternativas vêm sendo estudadas e propostas para a destinação final do biossólido. A seguir são apresentadas as principais encontradas na literatura.

\subsubsection{Alternativas não convencionais}

Para o biossólido originado de regiões onde prevalecem efluentes industriais com teores de metais pesados que não permitam o seu uso agrícola, Bettiol et al. (1983) recomendam a produção de um agregado leve que pode ser utilizado na construção civil, na substituição de brita em obras de concreto por exemplo. Tsutya (2000) relata que a SABESP utilizou com sucesso o agregado leve de biossólido para a fabricação de pré-moldados, utilizados na construção de vestiários e pisos de concreto em instalações de uso da instituição. Segundo o autor, o biossólido poderia ainda ser utilizado na produção de tijolos, substituindo a argila na proporção de $30 \%$ em volume, para a fabricação de tijolos comuns, e 5 a $8 \%$ em volume para tijolos de acabamento.

O biossólido gerado em certas regiões pode servir como matéria prima para a exploração de metais preciosos. Entretanto, para que a extração seja econômica deve haver concentração significativa do metal e produção suficiente de biossólido. Na Austrália foram encontradas concentrações de ouro e prata no biossólido de 0,77 e $18,80 \mathrm{~g} \mathrm{t}^{-1}$, respectivamente (Reeves et al., 1999).

\subsubsection{Disposição oceânica}

Em cidades costeiras, o biossólido e normalmente o próprio esgoto coletado, vem sendo lançado no oceano como forma de destinação final. A justificativa econômica dessa alternativa é a redução dos custos, 
principalmente com o transporte do biossólido. O grande risco desta prática é a contaminação do próprio meio oceânico e de praias utilizadas para recreação. Nesta alternativa, o biossólido, ou o próprio esgoto coletado, deve ser lançado a uma distância da costa tal que os riscos de contaminação sejam minimizados e que não prejudique a flora e fauna oceânicas. Esta prática, ainda empregada no Brasil, foi proibida nos EUA e em alguns paises europeus devido aos seus impactos ambientais negativos (Monney, 1992).

\subsubsection{Incineração}

Segundo Associação Brasileira de Normas Técnicas (1990), a incineração é o processo de oxidação à alta temperatura que destrói ou reduz o volume, podendo ainda recuperar materiais ou substâncias. O objetivo da incineração do biossólido é a de reduzir seu volume e toxidez, convertendo-o em gases ou resíduos incombustíveis (Bidone, 1998). Na incineração a massa inicial do biossólido é reduzida em até 5 vezes, restando apenas os sólidos fixos (Karabolad et al., 1998). Essa alternativa normalmente é empregada quando a contaminação do biossólido é muito alta, ou quando há escassez de áreas adequadas à implementação de outras alternativas, como no Japão, por exemplo (Endo et al., 1997).

A incineração do biossólido, além de ser potencialmente poluidora da atmosfera, consome grande quantidade de energia e requer elevados investimentos em filtros para a retenção dos gases tóxicos produzidos (Estados Unidos, 1986). Nos EUA a incineração de biossólido foi proibida em 1992 (Harrison et al., 1993). No Estado de São Paulo existem cinco incineradores aptos a receber o biossólido, onde o custo de incineração pode alcançar o valor de $R \$ 2,00$ por quilograma de resíduo, dependendo das características do material (Rocha, 1998). No Japão, onde a incineração é a alternativa predominante para a destinação final do biossólido, foi desenvolvido um processo industrial economicamente viável que transforma as cinzas provenientes da incineração em vidro cerâmico (Endo et al., 1997). 


\subsubsection{Recuperação de áreas degradadas}

O biossólido possui um teor significativo de matéria orgânica, e seus efeitos positivos no solo têm sido comprovados por diversos autores. A matéria orgânica aumenta a atividade microbiana, melhora a circulação de água e a aeração, sendo a principal responsável pela estruturação física do solo (Raij, 1998; Kiehl, 1985 e Primavesi, 1979). Outros efeitos da matéria orgânica no solo são a fixação, complexação ou quelação de elementos tóxicos, como os metais pesados, tornando-os indisponíveis para as plantas (Wang, 1997). Devido a essas características, o biossólido pode ser distribuído em áreas degradadas para melhorar as propriedades físicas e químicas do solo. Por exemplo, McNab \& Berry (1985) aplicando $34 \mathrm{t} \mathrm{ha}{ }^{-1}$, em base seca, de biossólido em uma área degradada no Estado da Geórgia (EUA) verificaram, após 5 anos do plantio, aumento de 92 e 300\% na produção de biomassa total em Pinus echinata e $P$. taeda, respectivamente, em comparação com a fertilização mineral (896 kg ha ${ }^{-1}$ de NPK 10-10-10 + 1.417 kg ha-1 de CaO).

Além das características do biossólido (teores de microrganismos patogênicos e de elementos químicos e orgânicos perigosos) e dos sítios de aplicação (tipo de solo, profundidade dos aqüíferos etc.), os pesquisadores recomendam especial atenção à topografia dessas áreas para a aplicação do biossólido, uma vez que elas geralmente apresentam solos descobertos e sujeitos à erosão (Companhia de Saneamento Básico do Paraná, 1997 e Deus et al., 1996).

\subsubsection{Landfarming ("Fazenda de Lodo ${ }^{4 ")}$}

Essa forma de disposição para o biossólido, basicamente, se resume à mistura do resíduo com a camada arável do solo. Ela permite que a parte orgânica do resíduo seja degradada biologicamente, e que a parte inorgânica seja transformada ou fixada na camada superior do solo (Bidone, 1998). O

\footnotetext{
${ }^{4}$ Tradução sugerida por Bidone (1998),
} 
mesmo autor salienta que um "landfarming" mal projetado pode proporcionar efeitos imediatos de contaminação de águas superficiais e subterrâneas, do ar e do solo. Embora seja bastante utilizada no exterior, principalmente nos EUA, no Brasil não há registros do uso dessa forma de destinação para o biossólido.

\subsubsection{Disposição em aterros sanitários}

A disposição do biossólido em aterros pode se dar de duas formas: (i) a disposição conjunta com os resíduos sólidos urbanos, genericamente denominados de lixo; e (ii) a disposição em aterros construídos exclusivamente para esse fim. No Estado de São Paulo, a co-disposição com o lixo urbano só é permitida para biossólidos cujas concentrações de contaminantes não ultrapassem os valores da Tabela 2.

Tabela 2. Limites para a concentração de contaminantes no biossólido para a sua co-disposição com resíduos sólidos urbanos em aterros sanitários.

\begin{tabular}{lc}
\hline \multicolumn{1}{c}{ CONTAMINANTE } & LIMITES $\left(\mathrm{mg} \mathrm{kg}^{-1}\right)$ \\
\hline Cádmio & 200 \\
Chumbo & 2.000 \\
Cobre & 5.000 \\
Cromo Total & 5.000 \\
Mercúrio & 40 \\
Níquel & 4.000 \\
Zinco & 10.000 \\
Arsênio & 1.000 \\
Molibdênio & 7.000 \\
Selênio & 200 \\
Berílio & 150 \\
Antimônio & 1.000 \\
Bário & 20.000 \\
Cianetos (por hidrólise) & 1.000 \\
Cobalto & 16.000 \\
Fluoretos & 36.000 \\
Prata & 1.000 \\
Vanádio & 4.800 \\
\hline
\end{tabular}

Fonte: Adaptado de Companhia de Saneamento Básico do Estado de São Paulo (1996). 
A co-disposição com lixo urbano em um aterro sanitário localizado ao lado da Rodovia dos Bandeirantes é o destino final dado ao biossólido produzido na ETE de Barueri. A disposição do biossólido no aterro só é permitida pela Prefeitura Municipal de São Paulo desde que seu peso não ultrapasse $5 \%$ do peso dos resíduos urbanos dispostos e a sua umidade não supere $60 \%$ (Tsutya, 2000). O autor salienta que o grande inconveniente dessa prática é a diminuição da vida útil dos aterros destinados a deposição dos resíduos sólidos, e que ela só é viável quando há a cooperação entre os responsáveis pela produção de biossólido e pela coleta e tratamento do resíduo sólido urbano.

A construção e manutenção dos aterros, exclusivos ou não, é baseada em critérios específicos a fim de garantir o confinamento dos resíduos dispostos com o mínimo risco para o ambiente e para a saúde pública (Bidone, 1998). Essa alternativa exige áreas relativamente próximas dos centros geradores, uma vez que o custo com o transporte é normalmente elevado.

Os principais aspectos negativos dessa prática são a exalação de odor desagradável, quando o biossólido não for devidamente estabilizado, e a poluição visual, o que tem causado reclamações justificáveis das populações vizinhas aos aterros. Em termos volumétricos, a disposição em aterros sanitários é a forma de destino final mais comum para o biossólido, tanto no Brasil como no exterior (Bidone, 1998).

Quando considerada a possibilidade de sua reciclagem, como insumo na produção agrícola por exemplo, a disposição do biossólido em aterros sanitários é inadequada e infelizmente ainda não se vislumbra no curto prazo solução técnica, economicamente viável, para o problema. No Estado de São Paulo, Tsutya (2000) e Karabolad et al. (1998) justificam a construção de aterros exclusivos para: (i) disposição de biossólidos com características inadequadas para os usos que estiverem sendo praticados; (ii) para absorver o excedente da demanda; e (iii) para a disposição de cinzas de incineração, caso esta solução venha a ser implementada. Os autores ressaltam, ainda, que os 
aterros exclusivos são a garantia de destinação adequada do biossólido, independente de quaisquer fatores. Segundo Karabolad et al. (1998), a construção de aterros exclusivos, embora necessária, apresenta um custo bastante elevado que pode alcançar o valor de $R \$ 244,00$ por tonelada seca disposta.

Há uma tendência mundial no sentido de proibir a disposição do biossólido em aterros como alternativa para a sua destinação final. A Comunidade Econômica Européia, por exemplo, formulou uma diretiva adotada pelos países membros, proibindo a partir de 2.002 o uso de aterros sanitários como destino final para resíduos com possibilidade de reciclagem. Nos EUA esse prazo foi estabelecido para 2.004 (Andreoli \& Pergorini, 1998). Há uma expectativa de que essa tendência mundial também venha a ser seguida pelo Brasil.

Segundo Tsutya (2000), a SABESP, através de uma avaliação das principais alternativas de destinação final para o biossólido, concluiu que o aterro exclusivo e o uso agrícola foram as únicas possibilidades viáveis para o biossólido produzido nas ETEs da Região Metropolitana de São Paulo (RMSP) (Anexo). Segundo o autor, as demais alternativas seriam viáveis para cidades pequenas e para situações particulares que as viabilizassem.

O uso como fertilizante orgânico e/ou condicionador de solos é uma alternativa promissora que vem sendo proposta para a destinação final do biossólido. Essa alternativa será tratada mais detalhadamente a seguir.

\subsection{Uso de biossólido e outros resíduos orgânicos como fertilizante}

A utilização do biossólido como fertilizante orgânico e condicionador de solos é apontada por diversos autores como a alternativa mais adequada para a sua destinação final (Andreoli et al., 1999; Ayuso et al. 1996 e Henry et al., 1994). Na Europa e nos EUA há uma expectativa de que esta alternativa e 
a incineração sejam futuramente as formas de destinação final predominantes para o biossólido (Matthews, 1998).

O biossólido gerado nas ETEs é proveniente do tratamento de esgotos industriais e principalmente dos domésticos. Normalmente, uma pessoa produz aproximadamente 1,8 litros de dejetos por dia, o que representa 350 gramas de matéria seca incluindo 90 gramas de matéria orgânica, 20 gramas de nitrogênio além de outros nutrientes, principalmente fósforo e potássio que se acumulam no biossólido (Organização Mundial da Saúde, s.d.). Com o tratamento do esgoto a concentração dos microrganismos patogênicos no biossólido é reduzida, a matéria orgânica é estabilizada e os nutrientes convertidos em formas mais disponíveis para as plantas, o que permite o seu uso como fertilizante (Organização Mundial da Saúde, s.d.). A matéria orgânica, os macro e micronutrientes encontrados no biossólido podem ser disponibilizados para as plantas, proporcionando ganhos de produtividade e economia em fertilizantes minerais. A análise dos dados apresentados na Tabela 3 mostra o potencial fertilizante do biossólido.

Tabela 3. Composição média de amostras de esterco de animais e de biossólido.

\begin{tabular}{|c|c|c|c|c|c|c|c|c|c|c|c|}
\hline \multirow[b]{2}{*}{ Resíduo } & \multicolumn{11}{|c|}{ COMPONENTE } \\
\hline & U & M.O. & $N$ & $P$ & K & $\mathrm{Ca}$ & $\mathrm{Mg}$ & $\mathrm{Na}$ & $\mathrm{Fe}$ & $\mathrm{Cu}$ & $\mathrm{Zn}$ \\
\hline & $\%$ & $\ldots$ & 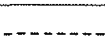 & $\ldots$ & $\mathrm{g} \mathrm{kg}^{-1}$ & 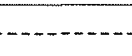 & 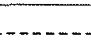 & 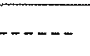 & 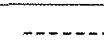 & $\mathrm{mg} \mathrm{kg}^{-1}$ & $\cdots$ \\
\hline Galinha ${ }^{a}$ & 35 & $52^{b}$ & 3,63 & 1,54 & 2,64 & 1,99 & 0,52 & 0,74 & 80 & 1.000 & 298 \\
\hline Bovino ${ }^{a}$ & 56 & $57^{b}$ & 1,81 & 0,55 & 2,28 & 1,51 & 0,43 & 0,21 & 2.100 & 14 & 155 \\
\hline Suino ${ }^{a}$ & 62 & $53^{b}$ & 2,32 & 2,06 & 1,62 & 3,25 & 0,77 & 0,96 & 8.800 & - & 422 \\
\hline Biossólido ${ }^{c}$ & 63 & $133^{\mathrm{d}}$ & 17,61 & 8,51 & 0,79 & 116,60 & 4,32 & 0,67 & - & 493 & 2.043 \\
\hline
\end{tabular}

Fonte: ${ }^{a}$ Adaptado de Holanda $(1981)^{5}$ citado por Kiehl (1985); ${ }^{b}$ Adaptado de Kiehl (1985); ' Adaptado de Poggiani \& Benedetti (2000).

'Valor médio, calculado pelo autor, para 9 amostras coletadas entre os meses de julho a dezembro de 1999.

d Carbono Orgânico total.

U: Umidade.

M.O.: Matéria Orgânica.

- Dado não disponível.

${ }^{5}$ HOLANDA, J.S. Utilização de esterco e adubo mineral em quatro seqüências de culturas em solo de Encosta Basáltica do Rio Grande do Sul, 1981. 1v. Dissertação (Mestrado) Faculdade de Agronomia, Universidade Federal do Rio Grande do Sul. 
2.3.1 Possíveis contaminantes encontrados no biossólido

A reciclagem agrícola do biossólido é, na maioria dos casos, limitada pela sua concentração de contaminantes, principalmente no que se refere aos metais pesados e nitratos. Neste aspecto, Andreoli et al. (1999) salientam que a geração de um resíduo que apresente características adequadas para a reciclagem agrícola depende da revisão dos padrões mínimos do esgoto recebido na rede coletora.

Os principais contaminantes que podem ser encontrados no biossólido podem ser resumidos em dois grupos: (i) os elementos químicos e orgânicos perigosos, e (ii) os microrganismos patogênicos.

\subsubsection{Elementos químicos e orgânicos perigosos}

Os metais pesados são os elementos mais estudados no grupo dos químicos perigosos. O termo "metal pesado" é normalmente empregado para elementos que apresentam densidade maior que $5 \mathrm{~g} \mathrm{~cm}^{-3}$. Geralmente, o termo "metal pestado" tem uma conotação negativa devido à sua potencial toxidez para plantas, animais e humanos. Entretanto, King (1996) salienta que muitos desses elementos são considerados como essenciais às plantas ( $\mathrm{Cu}, \mathrm{Mo}$, $\mathrm{Zn}$ ), às bactérias fixadoras de nitrogênio ( $\mathrm{Co}$ ), e aos animais ( $\mathrm{As}, \mathrm{Co}, \mathrm{Cr}, \mathrm{Cu}$, Mo, Se e $\mathrm{Zn}$ ).

$\mathrm{Na}$ aplicação de metais no solo, via biossólido, eles podem representar riscos no próprio local de aplicação ou pela sua translocação e/ou lixiviação e conseqüente contaminação de outros locais. A disponibilidade dos metais é influenciada por diversos fatores, como $\mathrm{pH}$ e CTC (Capacidade de Troca Catiônica) do solo, estado de oxidação do elemento, natureza dos complexos formados, taxa em que o elemento é liberado na solução etc. (King, 1996 e Polglase \& Myers, 1995). A lixiviação dos metais no solo depende das condições locais, como tipo e cobertura do solo, pH etc. No solo eles podem 
ainda ser complexados e se tornar indisponíveis. Consequentemente, a concentração de metais pesados no biossólido não necessariamente se apresenta prontamente disponível para as plantas, microrganismos ou para a lixiviação. Entretanto, o risco de contaminação ainda existe.

Medalie et al. (1994) afirmam que uma combinação de fatores físicos, químicos e biológicos (normalmente a absorção pelas plantas) limita a movimentação do biossólido e de seus componentes nos sítios de aplicação. Já a absorção de metais pelas plantas depende de sua concentração no biossólido e da preferência das espécies (King, 1996).

Quando absorvidos, os metais podem se acumular diferentemente nos componentes das plantas, podendo limitar o seu desenvolvimento. Riddell Black et al. (1997) avaliaram a capacidade de absorção de metais por Salix sp. em um solo que recebeu doses anuais de biossólido, supostamente contaminado por metais, durante mais de 50 anos. Os autores concluíram que a produtividade dessas espécies não foi influenciada pelas concentrações de $\mathrm{Zn}$ e Cd. Entretanto, ela foi substancialmente reduzida quando as concentrações de Cu e $\mathrm{Ni}$ eram superiores a $30 \mathrm{mg} \mathrm{kg}^{-1}$ na casca das árvores.

Andrade (1999), em um experimento localizado no Município de Itatinga, SP, onde utilizaram-se doses, em base seca, de 10, 20 e $40 \mathrm{t} \mathrm{ha}^{-1}$ de biossólido em Eucalyptus grandis, concluiu que a aplicação do resíduo não provocou movimentação no solo e nem a fitodisponibilidade de $\mathrm{Cd}, \mathrm{Cu}, \mathrm{Cr}$ e Ni após 360 dias da aplicação. Entretanto, foi constado aumento na disponibilidade de $\mathrm{N}$ às plantas.

Outro aspecto relevante sobre os metais pesados, aplicados via biossólido, é o seu potencial de contaminar os animais silvestres, seja pela ingestão direta do biossólido nos sítios de aplicação ou indiretamente através da cadeia trófica. Nickelson \& West (1996) analisaram as concentrações de Cd em pequenos mamíferos onívoros (Peromyscus sp.) e insetívoros (Sorex $\mathrm{sp}$.) amostrados em povoamentos de Pseudotsuga menziesii fertilizados com biossólido aos 4, 11 e 15 anos antes da amostragem. Os níveis de $\mathrm{Cd}$ nos insetívoros foram significativamente maiores em todos os tratamentos. 
Entretanto, os autores concluíram que o biossólido provavelmente não tem um efeito significativo a longo prazo nos onívoros e que a elevação dos níveis de Cd provavelmente não seria biologicamente significativa.

Os metais encontrados no biossólido são oriundos, principalmente, de atividades industriais. Na maioria dos paises, inclusive no Brasil, o lançamento de esgotos industriais contaminados com metais pesados na rede pública sem tratamento prévio é proibida por lei. O controle efetivo dessa fonte de contaminação é uma forma eficiente na redução da concentração de metais no biossólido. No Estado de Massachusetts, EUA, por exemplo, a análise de duas amostras de biossólido, coletadas em intervalos de quase 20 anos, demonstrou que a concentração dos principais metais foi substancialmente reduzida no período (Russell \& Yuhsia, 1996). O resultado foi atribuído a campanhas institucionais de redução da poluição.

Pesquisas têm demonstrado que a elevada concentração de nitrogênio no biossólido provavelmente será o fator mais limitante para o seu uso como fertilizante (Oliveira, 1995; Polglase \& Myers, 1995 e Henry et al., 1994). O nitrogênio apresenta alta mobilidade no solo, o que potencializa a lixiviação e possivel contaminação dos aqǘferos por sais, especialmente os nitratos, quando consideradas altas taxas de aplicação. Devido à potencial toxidez do nitrato, a taxa máxima de aplicação de biossólido em culturas agrícolas e florestais pode ser calculada em função da necessidade de nitrogênio da cultura durante o seu ciclo de produção e da Taxa de Mineralização do Nitrogênio (TMN) do biossólido (Companhia de Tecnologia de Saneamento Ambiental, 1999). Já a TMN varia, principalmente, com o tipo de biossólido (Tabela 4). 
Tabela 4. Nitrogênio disponível em diferentes tipos de biossólido após um ano de aplicação solo.

\begin{tabular}{lcc}
\hline \multicolumn{1}{c}{ TIPO DE BIOSSÓLIDO } & LÍQUIDO & PRENSADO \\
\hline & 22,7 a 36,3 & 9,1 a 18,2 \\
Não digerido & 13,6 a 27,2 & 7,3 a 13,6 \\
Digerido aeróbicamente & 13,6 a 27,2 & 4,5 a 9,1 \\
Digerido anaeróbicamente & - & 0,7 a 4,5 \\
Compostado & - & $\mathrm{kg} \mathrm{t}$
\end{tabular}

Fonte: Adaptado de Hart et al. (1988) ${ }^{6}$ citado por Andrade (1999).

- Dado não disponível.

Quando a dose de biossólido for elevada e a TMN permitir, pode haver movimentação de Nitrato no perfil do solo e contaminação do lençol freático (Glória, 1992 citado por Andrade (1999).

O potencial de lixiviação dos nutrientes aplicados ao solo via biossólido é diretamente relacionado com a dose aplicada. A dose adequada de aplicação de biossólido deve ser estimada considerando a necessidade nutricional das plantas, uma vez que a utilização de doses elevadas pode promover a lixiviação de nutrientes, especialmente o nitrogênio (Harrison et al., 1999). Na determinação de uma taxa segura de aplicação de biossólido em florestas de coníferas e folhosas nos EUA, Brockway \& Urie (1983) concluíram que a aplicação de doses, em base seca, de até $16,5 \mathrm{tha}^{-1}$ em coníferas (Pinus strobus) e $19,0 \mathrm{t} \mathrm{ha}^{-1}$ em folhosas (Populus grandidentata) manteve a qualidade da água dentro dos limites de potabilidade daquele país em termos de contaminação por nitratos. Os autores recomendam a análise do solo e da água dos aqǘferos próximos antes da aplicação do biossólido e, no mínimo, a cada 5 anos, a fim de determinar o pH, o estado nutricional, a concentração de metais e de patógenos.

\footnotetext{
${ }^{6}$ HART, J.B.; NGUYEN, P.V.; URIE, D.H. et al. Silvicultural use of wastewater sludge. Journal of Forestry, n.8, p.17-24, 1988.

${ }^{7}$ GLÓRIA, N.A. Uso agronômico de resíduos. In: REUNIÃO BRASILEIRA DE FERTILIDADE DO SOLO E NUTRIÇÃ̃O DE PLANTAS, 22., Piracicaba, 1992. Anais. Piracicaba: Fundação Cargil, 1992. P.195-212.
} 
$\mathrm{Na}$ avaliação de um experimento conduzido por Oliveira (1995) em casa de vegetação onde foi analisado o efeito de doses de biossólido equivalentes a 25, 50, 75 e $150 \mathrm{t} \mathrm{ha}^{-1} \mathrm{em}$ dois diferentes solos (Areia Quartzosa e Latossolo Roxo), conclui-se que a lixiviação das formas nitrogenadas $\left(\mathrm{N}-\mathrm{NO}_{3}{ }^{-}\right.$e $\left.\mathrm{N}-\mathrm{NH}_{4}{ }^{+}\right)$ aumentou com as doses aplicadas, sendo o aumento mais acentuado na Areia Quartzosa. Aos 63 dias após a aplicação do biossólido, o autor observou fitodisponibilidade de metais pesados $(\mathrm{Cd}, \mathrm{Cu}, \mathrm{Cr}, \mathrm{Ni}$ e $\mathrm{Zn}$ ) apenas para a dose equivalente a $150 \mathrm{t} \mathrm{ha}^{-1}$.

Uma das formas de diminuir a lixiviação de nitratos nos solos florestais é a aplicação de quantidades de nitrogênio equivalentes às que as plantas possam absorver e armazenar. Em espécies do gênero Eucalyptus, por exemplo, a capacidade de armazenamento de nitrogênio apresenta valores de 80 a $150 \mathrm{~kg} \mathrm{ha}^{-1} \mathrm{ano}^{-1}$ nos dois primeiros anos de crescimento, reduzindo-se para 50 a $100 \mathrm{~kg} \mathrm{ha}{ }^{-1}$ ano $^{-1}$ após esse período. Com o fechamento de copa ocorre a desrama, e cerca de 50 a $130 \mathrm{~kg} \mathrm{ha}^{-1} \mathrm{ano}^{-1}$ de nitrogênio retornam para o solo da floresta (Stewart et al., $1990^{8}$ e Cromer et al., $1993^{9}$ citados por Polglase \& Myers, 1995).

A presença de outros elementos químicos perigosos no biossólido tem sido comprovada. Um estudo realizado pelo Departamento Estadual de Saúde de Washington, comprovou a presença de 18 elementos radioativos no biossólido amostrado em 5 grandes centros populacionais dos EUA. Foram detectados Berílio-7, Césio-137, Cobalto-57 entre outros. As prováveis origens dos radioisótopos foram atribuídas à medicina, à indústria e a causas naturais. A instituição concluiu que as concentrações dos elementos no biossólido não causam riscos a saúde pública (Brennan, 1997).

Outros tipos de contaminantes que podem estar presentes no biossólido são os elementos orgânicos tóxicos. Ainda pouco estudados, suas

${ }^{8}$ STEWART, H.T.L.; HOPMANS, P.; FLINN, D.W. Nutrient accumulation in trees and soil following irrigation with municipal effluent in Australia. Environmental Pollution, v.63, p.155-177, 1990.

${ }^{9}$ CROMER, R.N.; CAMERON, D.M.; RANCE, S.J. et al. Response to nutrients in Eucalyptus grandis. 2. Nitrogen accumulation. Forest Ecology Management, n.62, p.231-243, 1993. 
concentrações no biossólido e seus efeitos no solo, nas plantas e nos animais ainda não são devidamente conhecidos. Na China, os elementos tóxicos orgânicos são os principais poluentes no biossólido, juntamente com os metais pesados (Wang, 1997). No Brasil, o Centro de Vigilância Sanitária lista uma série de componentes orgânicos que podem ser prejudicais à saúde humana (Tabela 5).

Tabela 5. Valores máximos permissíveis para componentes orgânicos da água potável.

\begin{tabular}{lc}
\hline \multicolumn{1}{c}{ COMPONENTES ORGÂNICOS } & LIMITES $\left(\mu \mathrm{g} \mathrm{L}^{-1}\right)$ \\
\hline Aldrim e Dieldrin & 0,03 \\
Benzeno & 10,00 \\
Benzeno-A-Pireno & 0,01 \\
Clordano (Total de isômeros) & 0,30 \\
DDT (P-P'; O-P'DDT; P-P'DDE; O-P'DDE) & 1,00 \\
Endrin & 0,20 \\
Heptacloro e Heptacloro Epóxido & 0,10 \\
Hexaclorobenzeno & 0,01 \\
Lindano (Gama HCH) & 3,00 \\
Metoxicloro & 30,00 \\
Pentaclorofenol & 10,00 \\
Tetracloreto de carbono & 3,00 \\
Tetracloroetano & 10,00 \\
Toxofeno & 5,00 \\
Tricloroeteno & 30,00 \\
Trihalometanos & $100,00^{1}$ \\
1,1 Dicloroetano & 0,30 \\
1,2 Dicloroetano & 10,00 \\
2,4 D & 100,00 \\
2,4,6 Triclorofenol & $10,00^{2}$
\end{tabular}

Fonte: Adaptado de Brasil (1990).

${ }^{1}$ Sujeito a revisão em função dos estudos toxicológicos em andamento.

${ }^{2}$ Concentração limiar de odor de $0,1 \mu \mathrm{g} \mathrm{L}$. 


\subsubsection{Organismos patogênicos}

Basicamente, os organismos patogênicos que podem ser encontrados no biossólido são os fungos, vírus, bactérias e parasitas, sendo as suas concentrações dependentes da origem do esgoto e do sistema de tratamento empregado (Sccol, 1998).

Segundo Organização Mundial da Saúde (s.d.) o uso de fezes humanas ou produtos oriundos destas na agricultura representa riscos à saúde pública, em relação aos patógenos, quando ocorrer a seguinte seqüência de eventos:

a) a concentração dos patógenos atingir uma dose infectante, seja pelo lançamento direto ou por sua multiplicação nos locais onde foram lançados;

b) a dose infectante alcançar um hospedeiro humano;

c) o hospedeiro for efetivamente infectado; e

d) a infecção causar doença ou posterior transmissão.

O risco potencial representado pelos patógenos no biossólido pode ser reduzido pelo adequado tratamento do resíduo antes de ser utilizado como fertilizante. A legislação americana considera como processos eficientes de redução de patógenos os seguintes: digestão aeróbia e anaeróbia termófilas, compostagem, radiação beta e gama, pasteurização, tratamento térmico e calagem (Sccol, 1998). Experimentalmente comprovou-se que a produção de fertilizante organo-mineral com a proporção de $70 \%$ de fertilizante mineral e $30 \%$ de biossólido também é efetiva na redução de patógenos, alcançando índices de $100 \%$ de eliminação de Salmonella e de ovos de helmintos (Companhia de Tecnologia de Saneamento Ambiental, s.d.). Todavia, quando os organismos não são totalmente eliminados há um risco potencial do aumento de sua população, normalmente associado a condições ambientais favoráveis à sua multiplicação (Gibbs et al., 1997). A Taenia sp., por exemplo, pode sobreviver em solos tratados com biossólido por mais de um ano (Kempton \& Cusack, 1999). 
Existem poucas evidências de que as pessoas que residam próximas aos locais ande o biossólido é aplicado são afetadas de forma negativa, depois do contato com o solo ou com trabalhadores desses locais, especialmente quando o padrão de higiene pessoal é alto (Organização Mundial da Saúde, s.d.).

\subsubsection{Aspectos legais}

As restrições legais afetam a viabilidade do uso de biossólido como fertilizante na medida em que restringem as áreas potenciais de aplicação e geram custos a essa atividade, como por exemplo, o de monitoramento das áreas fertilizadas.

O uso de biossólido como fertilizante é normatizado em diversas partes do mundo (Tabela 6). É importante salientar que os valores apresentados na Tabela 6 podem se referir somente a uma parte da legislação. Nesse caso o biossólido pode ser classificado em diferentes tipos, de acordo com seu uso, incluindo restrições para outros tipos de contaminantes.

Os limites dos poluentes adotados em diferentes países ou regiões (localidades) normalmente refletem características locais. Por exemplo a Holanda, país com uma área relativamente pequena, tem uma das mais rigorosas legislações acerca do biossólido do mundo. Em alguns paises há um sistema legislativo hierárquico, com legislação federal prevalecendo sobre a dos Estados membros, podendo a legislação estadual restringir mais que a federal.

No Brasil, a resolução 01/86 do Conselho Nacional do Meio Ambiente (CONAMA) trata do assunto e estabelece a obrigatoriedade da apresentação do Estudo de Impacto Ambiental e do Relatório de Impacto Ambiental (EIA/RIMA) quando o biossólido é disposto em aterros ou incinerado. A norma NBR 10.004 da Associação Brasileira de Normas Técnicas (ABNT) "classifica os resíduos sólidos quanto aos riscos potenciais ao meio ambiente e à saúde pública, para que possam ter manuseio e destinação adequados" (Associação Brasileira de Normas Técnicas, 1987). 
Tabela 6. Concentração máximas de elementos químicos no biossólido para seu uso como fertilizante em diversos locais do mundo.

\begin{tabular}{|c|c|c|c|c|c|c|c|c|c|c|c|c|}
\hline \multirow[b]{2}{*}{ LOCAL } & \multicolumn{12}{|c|}{ ELEMENTO } \\
\hline & As & $B$ & $\mathrm{Cd}$ & $\mathrm{Co}$ & $\mathrm{Cr}$ & $\mathrm{Cu}$ & $\mathrm{Hg}$ & Mo & $\mathrm{Ni}$ & $\mathrm{Pb}$ & $\mathrm{Se}$ & $\mathrm{Zn}$ \\
\hline & $\cdots$ & 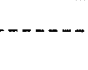 & 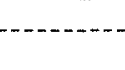 & $\cdots$ & $\cdots n$ & $\mathrm{~g} \mathrm{~kg}^{-1} \mathrm{e}$ & n base & seca & $\ldots$ & $\ldots$ & $\ldots$ & $\ldots$ \\
\hline $\begin{array}{l}\text { Alemanha } a^{1 \text { e } 2} \\
{ }^{*} \mathrm{pH} 5-6 \\
* \mathrm{pH}>6\end{array}$ & - & - & $\begin{array}{r}5,00 \\
10,00\end{array}$ & - & $\begin{array}{l}900 \\
900\end{array}$ & $\begin{array}{l}800 \\
800\end{array}$ & $\begin{array}{l}8,00 \\
8,00\end{array}$ & - & $\begin{array}{l}200 \\
200\end{array}$ & $\begin{array}{l}900 \\
900\end{array}$ & - & $\begin{array}{l}2.000 \\
2.500\end{array}$ \\
\hline Áustria ${ }^{1}$ & - & - & 5,00 & - & 400 & 400 & 7,00 & - & 80 & 400 & - & 1.600 \\
\hline Bélgica $^{1}$ & - & . & 12,00 & - & 500 & 750 & 10,00 & - & 100 & 600 & - & 2.500 \\
\hline $\begin{array}{l}\text { China }^{3} \\
{ }^{*} \mathrm{PH}<6,5 \\
{ }^{*} \mathrm{pH} \geq 6,5\end{array}$ & $\begin{array}{l}75 \\
75\end{array}$ & $\begin{array}{l}150 \\
150\end{array}$ & $\begin{array}{r}5,00 \\
20,00\end{array}$ & - & $\begin{array}{r}600 \\
1.000\end{array}$ & $\begin{array}{l}250 \\
500\end{array}$ & $\begin{array}{r}5,00 \\
15,00\end{array}$ & - & $\begin{array}{l}100 \\
200\end{array}$ & $\begin{array}{r}300 \\
1.000\end{array}$ & - & $\begin{array}{r}500 \\
1.000\end{array}$ \\
\hline Dinamarca $^{1}$ & - & - & 0,80 & - & 100 & 1.000 & 0,80 & - & 30 & 120 & - & 4.000 \\
\hline $\begin{array}{l}\text { Espanha }^{1} \\
{ }^{*} \mathrm{pH}<7 \\
{ }^{*} \mathrm{pH}>7\end{array}$ & - & - & $\begin{array}{l}20,00 \\
40,00\end{array}$ & - & $\begin{array}{l}1.000 \\
1.500\end{array}$ & $\begin{array}{l}1.000 \\
1.750\end{array}$ & $\begin{array}{l}16,00 \\
25,00\end{array}$ & - & $\begin{array}{l}300 \\
400\end{array}$ & $\begin{array}{r}750 \\
1.200\end{array}$ & - & $\begin{array}{l}2.500 \\
4.000\end{array}$ \\
\hline$E A^{4}$ & 41 & & 39,00 & - & - & 1.500 & 17,00 & - & 420 & 300 & 100 & 2.800 \\
\hline Finlândia ${ }^{1}$ & - & - & 3,00 & - & 300 & 500 & 2,00 & - & 30 & 150 & - & 500 \\
\hline França $^{1}$ & - & - & 20,00 & - & 1.000 & 1.000 & 10,00 & - & 200 & 800 & - & 3.000 \\
\hline Holanda ${ }^{1}$ & 15 & - & 1,25 & - & 75 & 75 & 4,75 & - & 30 & 100 & - & 300 \\
\hline Irlanda ${ }^{1}$ & - & - & 20,00 & - & - & 1.000 & 16,00 & - & 300 & 750 & - & 2.500 \\
\hline Itália ${ }^{1}$ & - & - & 20,00 & - & - & 1.000 & 10,00 & - & 300 & 750 & - & 2.500 \\
\hline Massachusetts ${ }^{5}$ & - & - & 14,00 & - & 1.000 & 1.000 & 10,00 & - & 2.000 & 300 & - & 2.500 \\
\hline Noruega $^{1}$ & - & - & 4,00 & - & 125 & 1.000 & 5,00 & - & 80 & 100 & - & 1.500 \\
\hline Nova Iorque ${ }^{2}$ & - & - & 10,00 & - & 100 & 1.000 & 10,00 & - & 200 & 250 & - & 1.000 \\
\hline Ontário $^{2}$ & 35 & - & 4,00 & 77 & 530 & 380 & 1,40 & 1,2 & 80 & 220 & 6 & 840 \\
\hline Suécia ${ }^{1}$ & - & - & 2,00 & - & 100 & 600 & 2,50 & - & 50 & 100 & - & 800 \\
\hline Suíça ${ }^{1}$ & - & - & 5,00 & - & 500 & 600 & 5,00 & - & 80 & 500 & - & 2.000 \\
\hline Texas $^{2}$ & 10 & - & 16,00 & - & 180 & 1.020 & 11,00 & 75,0 & 160 & 300 & 36 & 2.190 \\
\hline
\end{tabular}

Os resíduos são classificados pela norma NBR 10.004 da ABNT quanto à sua característica que, em função de suas propriedades físicas, químicas ou infecto-contagiosas, pode apresentar: 
a) risco a saúde pública, provocando ou acentuando, de forma significativa, um aumento de mortalidade ou incidência de doenças, e/ou:

b) riscos ao meio ambiente, quando o resíduo é manuseado ou destinado de forma inadequada.

São três as classes de resíduos:

a) Classe I: perigosos;

b) Classe II: não inertes (como o biossólido); e

c) Classe III: inertes (tijolos, vidros, certos plásticos e borrachas etc.).

No Estado de São Paulo a Companhia de Tecnologia de Saneamento Ambiental (CETESB) disciplina a coleta, transporte e disposição do biossólido. Recentemente, a CETESB normatizou o uso do biossólido como fertilizante e/ou condicionador de solos. A norma da CETESB se baseia fortemente na legislação norte americana elaborada pela "Environmental Protection Agency (EPA)", órgão de proteção ambiental norte americano. A "USEPA part 503" ou a "EPA 503" como é comumente conhecida, estabelece padrões mínimos de qualidade do biossólido para que possa ser aplicado no solo, com finalidade de fertilização ou não.

O norma da CETESB P 4.230" de janeiro de 1999 estabelece critérios e requisitos para 0 uso de biossólido ${ }^{10} \mathrm{em}$ áreas agrícolas $^{11}$ visando 0 atendimento de exigências ambientais. A CETESB, ainda, classifica e estabelece as concentrações máximas permitidas para patógenos e poluentes químicos (Tabelas 7 e 8), além de exigir redução na capacidade de atração de vetores, como moscas e roedores.

\footnotetext{
${ }^{10}$ Lodo resultante de tratamento biológico de despejos líquidos, com características tais que atende as condições da norma CETESB/P 4.230 - jan./99.

${ }^{11}$ Áreas agrícolas ou florestais, de produção ou de revegetação para recuperação de áreas degradas.
} 
Tabela 7. Densidades máximas de patógenos nos dois tipos de biossólido que podem ser aplicados em áreas agrícolas, segundo o Manual Técnico da CETESB (P 4.230 - jan./99).

\begin{tabular}{|c|c|c|c|c|}
\hline \multicolumn{2}{|c|}{ TIPO DE BIOSSÓLIDO } & \multicolumn{3}{|c|}{ DENSIDADE MÁXIMA DE PATÓGENOS } \\
\hline \multicolumn{2}{|l|}{ Classe A } & \multicolumn{3}{|c|}{$\begin{array}{l}1.000 \mathrm{NMP} \text { (número mais provável) de coliformes } \\
\text { fecais por grama de sólido totais ou } 3 \text { NMP de } \\
\text { Salmonella sp. a cada } 4 \text { gramas de sólido totais. }\end{array}$} \\
\hline \multicolumn{2}{|l|}{ Classe $B^{*}$} & \multicolumn{3}{|c|}{$\begin{array}{l}2.000 .000 \text { NMP de coliformes ou } 2.000 .000 \text { UFC } \\
\text { (Unidade Formadora de Colônia), por grama de } \\
\text { sólido totais. }\end{array}$} \\
\hline \multicolumn{5}{|c|}{$\begin{array}{l}\text { Fonte: Adaptado de Companhia de Tecnologia de Saneamento Ambiental (1999). } \\
\text { Classificação atribuída, também, quando o biossólido for submetido a processo para a } \\
\text { redução de patógenos aceito por órgão ambiental. }\end{array}$} \\
\hline \multicolumn{5}{|c|}{$\begin{array}{l}\text { Tabela 8. Limites das concentrações de poluentes químicos regulados pel } \\
\text { Manual Técnico da CETESB ( } P \text { 4.230 - jan./99) para aplicação de } \\
\text { biossólido em áreas agrícolas. }\end{array}$} \\
\hline \multirow[t]{2}{*}{ POLUENTES } & $\begin{array}{r}\text { Concentraçã } \\
\text { permiti } \\
\text { bioss } \\
\text { (base }\end{array}$ & $\begin{array}{l}\text { máximas } \\
\text { as no } \\
\text { lido } \\
\text { eca) }\end{array}$ & $\begin{array}{l}\text { Taxa de aplicação } \\
\text { anual máxima } \\
\text { (ano = } 365 \text { dias) }\end{array}$ & $\begin{array}{c}\text { Carga máxima } \\
\text { acumulada no solo } \\
\text { pela aplicação do } \\
\text { biossólido }\end{array}$ \\
\hline & (mg & $\left.g^{-1}\right)$ & $\left(\mathrm{kg} \mathrm{ha}^{-1} \mathrm{ano}^{-1}\right)$ & $\left(\mathrm{kg} \mathrm{ha}^{-1}\right)$ \\
\hline Arsênio & & & 2,00 & 41 \\
\hline Cádmio & & & 1,90 & 39 \\
\hline Cobre & 430 & & 75,00 & 1500 \\
\hline Chumbo & 84 & & 15,00 & 300 \\
\hline Mercúrio & & & 0,85 & 17 \\
\hline Molibdênio & & & - & - \\
\hline Níquel & 42 & & 21,00 & 420 \\
\hline Selênio & 10 & & 5,00 & 100 \\
\hline Zinco & 750 & & 140,00 & 2800 \\
\hline
\end{tabular}

Fonte: Adaptado de Companhia de Tecnologia de Saneamento Ambiental (1999).

Obs.: para o Cromo, adotou-se preliminarmente o limite de acumulação de $500 \mathrm{mg}$ a cada $\mathrm{Kg}$ de solo.

- Dado não disponível.

Para melhor caracterização do biossólido produzido na ETE de Barueri, e comparação com os limites apresentados nas Tabelas 7 e 8 , resumem-se nas Tabelas 9 e 10 dados sobre patogenicidade e presença de metais pesados nesse resíduo. 
Tabela 9. Densidades de alguns microrganismos encontrados em amostras de biossólido da ETE de Barueri.

\begin{tabular}{ccccc}
\hline \multirow{2}{*}{$\begin{array}{c}\text { Data de coleta } \\
\text { da amostra }\end{array}$} & $\begin{array}{c}\text { Coliformes } \\
\text { fecais } \\
\left(\text { NMP g }^{-1}\right)\end{array}$ & Colífagos & $\begin{array}{c}\text { Poliformes } \\
\text { totais } \\
\left(\text { NMP g }^{-1}\right)\end{array}$ & $\begin{array}{c}\text { Pesquisa de } \\
\text { protozoários }\end{array}$ \\
\hline $16 / 07 / 99$ & AUS & AUS & 43.000 & AUS \\
$20 / 08 / 99$ & AUS & AUS & 70.000 & AUS \\
$10 / 09 / 99$ & AUS & AUS & 46.000 & AUS \\
$24 / 09 / 99$ & AUS & AUS & 110 & AUS \\
$14 / 10 / 99$ & AUS & AUS & 1.100 & AUS \\
$25 / 10 / 99$ & AUS & AUS & 460.000 & AUS \\
$10 / 11 / 99$ & 4000 & AUS & 110.000 & AUS \\
$25 / 11 / 99$ & AUS & AUS & 750.000 & AUS \\
$27 / 12 / 99$ & AUS & AUS & 40.000 & AUS \\
\hline
\end{tabular}

Fonte: Adaptado de Poggiani \& Benedetti (2000).

${ }^{1}$ Presença ou ausência.

NMP: Número Mais Provável.

AUS: Ausente.

UFC: Unidade Formadora de Colônias.

Tabela 10. Concentrações médias e desvios padrão de alguns metais presentes em amostras de biossólido da ETE de Barueri.

\begin{tabular}{|c|c|c|}
\hline \multirow[t]{2}{*}{ ELEMENTO } & \multicolumn{2}{|c|}{ CONCENTRAÇÃO NO BIOSSÓLIDO $\left(\mathrm{mg} \mathrm{kg}^{-1}\right)$} \\
\hline & Média $^{1}$ & Desvio Padrão ${ }^{1}$ \\
\hline Arsênio (As) & ND & - \\
\hline Cádmio (Cd) & 7,0 & 1,6 \\
\hline Chumbo (Pb) & 141,1 & 16,7 \\
\hline Cobre $(\mathrm{Cu})^{*}$ & 493,1 & 81,0 \\
\hline Cromo hexavalente $(\mathrm{Cr})$ & ND & . \\
\hline Magnésio $(\mathrm{Mg})^{*}$ & $4.318,2$ & 770,0 \\
\hline Mercúrio $(\mathrm{Hg})$ & ND & - \\
\hline Molibdênio (Mo)* & 25,0 & 10,3 \\
\hline Níquel (Ni) & 290,7 & 71,4 \\
\hline Selênio (Se) & ND & - \\
\hline Sódio $(\mathrm{Na})$ & 672,4 & 218,0 \\
\hline Zinco $(Z n)^{*}$ & $2.043,0$ & 409,0 \\
\hline
\end{tabular}

Fonte: Adaptado de Poggiani \& Benedetti (2000).

${ }^{1}$ Parâmetros, calculados pelo autor, para 9 amostras coletadas entre os meses de julho a dezembro de 1999.

* Em concentrações adequadas são considerados micro-nutrientes.

ND: Abaixo do limite de deteç̧ão pelo método analítico empregado.

- Dado inexistente. 
Os níveis de metais pesados encontrados no biossólido da ETE de Barueri evidenciarem a necessidade de um controle no uso agrícola desse resíduo, em termos de taxas e intervalos de aplicação. Entretanto, verifica-se que alguns fertilizantes minerais, utilizados indiscriminadamente na agricultura, podem apresentar teores de metais pesados superiores aos encontrados no biossólido (Tabela 11).

Tabela 11. Concentração de metais pesados não nutrientes em diferentes tipos de fertilizantes minerais.

\begin{tabular}{lrrrr}
\hline \multicolumn{1}{c}{ FERTILIZANTE } & \multicolumn{4}{c}{ METAL $\left(\mathrm{mg} \mathrm{kg}^{-1}\right)$} \\
\hline & \multicolumn{1}{c}{$\mathrm{Cd}$} & $\mathrm{Pb}$ & $\mathrm{Cr}$ & \multicolumn{1}{c}{$\mathrm{Ni}$} \\
\cline { 2 - 5 } Rocha fosfatada Catalão & 3,7 & 58 & 19 & 45 \\
Concentrado apatítico fino Araxá & 7,0 & 127 & 44 & 97 \\
Superfosfato triplo & 2,6 & 2 & 14 & 3 \\
Superfosfato simples & 2,5 & 92 & 26 & 44 \\
Fosfato monoamônico (MAP) & 3,5 & 18 & 17 & 24 \\
Fosfato diamônico (DAP) & 2,7 & 1 & 17 & 24 \\
Termofosfato & 3,0 & 5 & 1.070 & 271 \\
NPK 4-14-8 & 11,0 & 169 & 19 & 30 \\
Fonte de micronutrientes: BR-5 & 563,0 & 121 & 30 & 103 \\
Fonte de micronutrientes: Nutricitro & 35,0 & 7.494 & 110 & 461 \\
\hline
\end{tabular}

Fonte: Adaptado de Gabe \& Rrodella (1999) $)^{12}$ citados por Rrodella \& Alcarde (2000)

A norma da CETESB estabelece, ainda, diferentes critérios para a definição da taxa máxima de biossólido que pode ser utilizada nas diferentes culturas, como descrito a seguir.

a) Taxa máxima de aplicação do biossólido em função do nitrogênio disponível

Devido a potencial lixiviação de nitratos no perfil do solo, quando o biossólido é aplicado em doses elevadas, o manual da CETESB estabelece o cálculo da taxa máxima de aplicação em função do teor de nitrogênio disponível no biossólido e da necessidade das plantas da seguinte forma:

12 GABE, U.; RODELLA, A.A. Trace elements in Brazilian agricultural limestones and mineral fertilizers. Communications in soil science and plants analysis, 30(5\&6), 605-620, 1999. 
$T M=\frac{N_{\text {Cultura }}}{N_{\text {Disp }}}$

em que:

TM = Taxa Máxima de aplicação do biossólido ( $t \mathrm{ha}^{-1}$ )

$\mathrm{N}_{\text {Cultura }}=$ quantidade de nitrogênio recomendada para a cultura $\left(\mathrm{kg} \mathrm{ha}^{-1}\right)$;

$\mathrm{N}_{\text {Disp }}=$ teor de nitrogênio disponível no biossólido $\left(\mathrm{kg} \mathrm{t}^{-1}\right)$.

Para verificar a quantidade de nitrogênio recomendada para a cultura, a CETESB sugere consultar o Boletim 100 do IAC. O teor de nitrogênio disponível no biossólido é calculado pelas seguintes equações:

$\mathrm{N}_{\text {Disp }}=\left(\frac{\mathrm{FM}}{100}\right) \times\left(\mathrm{N}_{\mathrm{Kj}}-\mathrm{N}_{\mathrm{NH} 3}\right)+\left(\mathrm{N}_{\mathrm{NH} 3}\right)+\left(\mathrm{N}_{\mathrm{N} 03}+\mathrm{N}_{\mathrm{NO} 2}\right)$

$\mathrm{N}_{\text {Disp }}=\left(\frac{F M}{100}\right) \times\left(\mathrm{N}_{\mathrm{Kj}}-\mathrm{N}_{\mathrm{NH} 3}\right)+0,5 \times\left(\mathrm{N}_{\mathrm{NH} 3}\right)+\left(\mathrm{N}_{\mathrm{NO3}}+\mathrm{N}_{\mathrm{NO2}}\right)$

em que:

FM = Fração de Mineralização do nitrogênio (\%);

$\mathrm{N}_{\mathrm{Kj}}=$ Nitrogênio Kjeldahl $\left(\mathrm{kg} \mathrm{t}^{-1}\right)$;

$\mathrm{N}_{\mathrm{NH3}}=$ Nitrogênio Amoniacal $\left(\mathrm{kg} \mathrm{t}^{-1}\right)$; e

$\mathrm{N}_{\mathrm{NO2}}=$ Nitrogênio Nitrito $\left(\mathrm{kg} \mathrm{t}^{-1}\right)$.

Obs.: A eq. (2) é utilizada para aplicação sub-superficial e a eq. (3) para aplicação superficial. 
b) Taxa máxima de aplicação do biossólido em função do teor de metais e seu limite de acumulação no solo

O biossólido pode apresentar teores elevados de metais pesados, principalmente os produzidos em ETEs de regiões com elevado grau de industrialização. Altos teores de metais pesados no biossólido inviabilizam a sua utilização como fertilizante devido à potencial toxidez desses elementos às plantas, aos animais e aos humanos.

O nível de contaminantes no biossólido afeta o seu potencial de uso uma vez que aqueles que não atendam os limites da Tabela 8 não poderão ser utilizados como fertilizante. Como referência, a Tabela 12 apresenta a concentração de alguns metais em amostras de biossólido gerado na ETE de Barueri. O único metal que superou os limites estabelecidos pela CETESB foi o Níquel, evidenciando a necessidade de um controle maior no lançamento de efluentes que possam contaminar o biossólido com esse elemento.

Na Tabela 12 é apresentada também a simulação de uma aplicação de $20 \mathrm{t} \mathrm{ha}^{-1}$ de biossólido, em base seca, a cada 7 anos em povoamentos de eucalipto. Observa-se, neste caso, que a taxa de aplicação anual máxima obtida na simulação (TAA) não superou a estabelecida pela CETESB (Tabela 8). O tempo necessário para se atingir a acumulação máxima de metais no solo estabelecida pela CETESB (TCAM) é bastante alto, e permite trabalhar com uma grande margem de segurança. 
Tabela 12. Concentração de alguns metais em amostras de biossólido da ETE de Barueri.

\begin{tabular}{|c|c|c|c|c|c|c|c|c|c|}
\hline \multirow{3}{*}{$\begin{array}{l}\text { Mês de } \\
\text { coleta da } \\
\text { amostra }\end{array}$} & \multicolumn{9}{|c|}{ METAL } \\
\hline & As & $\mathrm{Cd}$ & $\mathrm{Cu}$ & $\mathrm{Pb}$ & $\mathrm{Hg}$ & Mo & $\mathrm{Ni}$ & $\mathrm{Se}$ & $\mathrm{Zn}$ \\
\hline & \multicolumn{9}{|c|}{ Concentração $\left(\mathrm{mg} \mathrm{kg} \mathrm{kg}^{-1}\right)$} \\
\hline $\operatorname{Mar} / 93^{1}$ & 8,0 & 9,1 & 547,0 & 180,0 & 1,8 & 26,6 & 294,0 & 3,0 & 595,0 \\
\hline $\operatorname{Mar} / 93^{1}$ & 7,5 & 11,8 & 570,0 & 182,0 & 3,5 & 19,5 & 351,0 & 0,7 & $1.218,0$ \\
\hline $\mathrm{Abr} / 93^{1}$ & 16,8 & 23,6 & $1.167,0$ & 350,0 & 6,7 & 33,6 & $600,0^{*}$ & 1,7 & $2.469,0$ \\
\hline $\mathrm{Abr} / 93^{1}$ & 7,8 & 11,0 & 569,0 & 183,0 & - & 16,3 & 289,0 & ND & $1.154,0$ \\
\hline $\operatorname{Jan} / 95^{1}$ & 1,9 & 16,6 & $1.706,0$ & 259,0 & 4,8 & 23,3 & 244,0 & ND & $2.338,0$ \\
\hline Fev $/ 95^{1}$ & 0,7 & 17,1 & $1.470,0$ & 113,0 & 0,9 & 1,9 & 311,0 & ND & $2.396,0$ \\
\hline $\mathrm{Fev} / 95^{1}$ & 2,3 & 30,8 & $1.265,0$ & 195,0 & 2,2 & 39,3 & $432,0^{*}$ & ND & $1.710,0$ \\
\hline $\mathrm{Abr} / 95^{1}$ & 1,9 & 28,0 & 859,0 & 173,0 & 1,9 & 15,0 & $462,0^{*}$ & ND & $1.723,0$ \\
\hline Nov $/ 95^{1}$ & 9,1 & 37,6 & 944,0 & 322,0 & 1,0 & 33,9 & $500,0^{*}$ & ND & $2.403,0$ \\
\hline $\operatorname{Dez} / 95^{1}$ & 76,1 & 19,6 & 501,0 & 145,0 & 1,3 & 11,2 & 283,0 & ND & $2.506,0$ \\
\hline $\operatorname{Jan} / 96^{1}$ & 17,8 & 19,7 & 485,0 & 101,0 & 0,2 & 21,9 & 239,0 & ND & $2.127,0$ \\
\hline $\mathrm{Mar} / 96^{1}$ & 68,3 & 7,7 & 545,0 & 147,0 & 0,7 & 11,6 & 411,0 & ND & $1.889,0$ \\
\hline $\mathrm{Jul} / 99^{2}$ & ND & 6,7 & 503,0 & 137,0 & ND & 13,0 & 268,0 & ND & $1.706,0$ \\
\hline $\mathrm{Ago} / 99^{2}$ & ND & 5,9 & 344,0 & 119,0 & ND & 15,0 & 225,0 & ND & $2.350,0$ \\
\hline Set $/ 99^{2}$ & ND & 6,2 & 607,0 & 139,0 & ND & 19,0 & 292,0 & ND & $1.715,0$ \\
\hline Set $/ 99^{2}$ & ND & 6,8 & 556,0 & 162,0 & ND & 30,0 & 244,0 & ND & $1.667,0$ \\
\hline Out $/ 99^{2}$ & ND & 6,0 & 457,0 & 123,0 & ND & 23,0 & 328,0 & ND & $1.899,0$ \\
\hline Out $/ 99^{2}$ & ND & 6,1 & 502,0 & 152,0 & ND & 22,0 & $463,0^{*}$ & ND & $2.934,0$ \\
\hline Nov $/ 99^{2}$ & ND & 7,1 & 433,0 & 127,0 & ND & 36,0 & 244,0 & ND & $1.933,0$ \\
\hline Nov $/ 99^{2}$ & ND & 6,9 & 459,0 & 145,0 & ND & 45,0 & 281,0 & ND & $1.933,0$ \\
\hline $\mathrm{Dez} / 99^{2}$ & ND & 11,0 & 577,0 & 166,0 & ND & 22,0 & 271,0 & ND & $2.250,0$ \\
\hline Média $^{* *}$ & 18,2 & 14,1 & 717,4 & 172,4 & 2,3 & 22,8 & 334,9 & 1,8 & $1.948,0$ \\
\hline $\mathrm{IC}^{* *}( \pm)$ & 16,4 & 4,3 & 171,1 & 29,3 & 1,3 & 4,8 & 46,8 & 2,9 & 243,0 \\
\hline TAA $^{* *}$ & 0,10 & 0,05 & 2,54 & 0,58 & 0,01 & 0,08 & 1,09 & 0,01 & 6,26 \\
\hline $\mathrm{TACM}^{* *}$ & 415 & 745 & 591 & 521 & 1.652 & - & 385 & 7.503 & 447 \\
\hline
\end{tabular}

Fonte: ${ }^{1}$ Adaptado de Companhia de Saneamento Básico do Estado de São Paulo (1996); ${ }^{2}$ Adaptado de Poggiani \& Benedetti (2000).

ND: Não detectado pelo método analítico empregado.

IC: Intervalo de Confiança da média a $95 \%$.

TAA: Taxa de Aplicação Anual ( $\mathrm{kg} \mathrm{ha}^{-1} \mathrm{ano}^{-1}$ ), considerando uma dose de $20 \mathrm{t} \mathrm{ha} \mathrm{h}^{-1}$, em base seca, a cada 7 anos e os limites superiores do intervalo de confiança para os metais.

TACM: Tempo para Atingir a Carga Máxima de metais no solo (anos), considerando uma dose de $20 \mathrm{t} \mathrm{ha}^{-1}$, em base seca, a cada 7 anos e os limites superiores do intervalo de confiança para os metais.

* Valor superior ao estabelecido pela CETESB para uso agrícola.

** Parâmetros calculados pelo autor, considerando apenas os valores numéricos.

- Dado não disponível. 
c) Taxa máxima de aplicação do biossólido em função de elevação de pH do solo

A adição de materiais orgânicos decomponíveis no solo causa elevação de seu pH proporcional à quantidade de material adicionado (Andrade, $1999 \mathrm{e}$ Oliveira, 1995). Segundo Companhia de Tecnologia de Saneamento Ambiental (1999), a taxa de aplicação poderá, também, se basear na capacidade do biossólido de neutralizar a acidez do solo. Nesse caso, são considerados resultados de ensaios de elevação de $\mathrm{pH}$ provocado pelo biossólido, de modo a garantir que o pH final da mistura solo-biossólido não ultrapasse o limite de 7,0 (determinação em água).

d) Taxa de aplicação em função de outros nutrientes

A norma da CETESB estabelece, ainda, que a definição da taxa de aplicação de biossólido em áreas agrícolas poderá se basear no seu conteúdo de nutrientes e na necessidade nutricional das plantas, desde que devidamente justificado. A norma, entretanto, não especifica quais nutrientes, além do nitrogênio, poderão ser utilizados para a definição da taxa máxima de aplicação.

Outro aspecto tratado pela norma da CETESB é a localização das áreas agrícolas para a disposição do biossólido. Segundo Companhia de Tecnologia de Saneamento Ambiental (1999), na escolha da área para aplicação do biossólido devem ser considerados os aspectos referentes à "legislação vigente, especificamente a Legislação Florestal, quantidade de biossólido a ser aplicada, facilidade de acesso durante o período de aplicação, proximidade de áreas residenciais, direção predominante dos ventos, aprovações e consentimentos dos proprietários."

Quanto às limitações das áreas destinadas a aplicação do biossólido devem ser observados os seguintes itens: 
a) declividades máximas de 10 e $18 \%$ para aplicação superficial e subsuperficial, respectivamente;

b) manutenção de zonas de proteção de modo a não causar incômodos à vizinhança pela emissão de odores;

c) distâncias mínimas de 15 metros de vias de domínio público e 10 metros de drenos interceptores e diversores de águas superficiais de jusante e de trincheiras drenantes de águas subterrâneas e superficiais; e

d) profundidade entre a superfície do terreno e o nível do lençol freático superior a 1,2 metros na época de aplicação.

Em âmbito nacional, poder-se-ia aproveitar a experiência adquirida em outros países como caminho para a elaboração de uma norma brasileira, como ocorrido com o Estado de São Paulo. Entretanto, deve-se avaliar a adequação dos limites para os contaminantes ou a necessidade de inclusão de outros.

\subsubsection{Fertilização orgânica de povoamentos florestais: aspectos silviculturais e econômicos}

Grande parte dos povoamento florestais no Estado de São Paulo se encontra em solos classificados como Areia Quartzosa. Estes solos são ácidos, pobres em matéria orgânica e nutrientes minerais, baixa capacidade de retenção de cations e de água, alta saturação de alumínio, com teores de areia entre 85 a 98\% (Zen et al., 1994). Essas características limitam a capacidade de retenção de nutrientes dos fertilizantes químicos, promovendo elevadas perdas por lixiviação e impedindo a absorção adequada por parte das raízes.

O manejo intensivo das florestas plantadas causa conseqüências indesejáveis ao ambiente florestal. As mais relevantes são a compactação do solo e a exportação de nutrientes via produção. Ambos aumentam significativamente com o aumento da mecanização das atividades florestais (Harrison et al., 1996). O uso prolongado de fertilizantes minerais, que normalmente contém apenas os elementos $N, P$ e $K$, pode resultar em 
deficiências de outros elementos que não são repostos de forma adequada. Como conseqüência a produtividade potencial de espécies florestais, principalmente o eucalipto, tem sido limitada. O uso de resíduos orgânicos nesses locais contribuiria para minimizar os aspectos negativos do manejo intensivo das florestas plantadas.

Embora não existam referências do uso de biossólido em povoamentos florestais no Brasil, o uso de resíduos orgânicos na fertilização de povoamentos de eucalipto já vem sendo praticado em algumas empresas florestais, como forma de aumento de produtividade das espécies e diminuição de custos com o manejo dos resíduos produzidos (Moro, 1994 e Zen et al., 1994). A área fertilizada com cinza de biomassa florestal, resíduo celulósico e lama de cal em uma das empresas, por exemplo, representa cerca de 5.000 hectares anuais (Moro, 1994). O autor salienta a economia obtida nos custos com a fertilização devido à essa prática, e que o fator limitante à fertilização de povoamentos florestais com resíduos em escala comercial é o seu elevado custo, especialmente 0 de transporte, devido às altas doses utilizadas.

Na região norte do Estado de São Paulo, em um experimento de fertilização conduzido por Zen et al. (1994), a aplicação de $21 \mathrm{tha}^{-1}$, na entrelinha de plantio, de composto de resíduos urbanos em Eucalyptus grandis proporcionou um ganho volumétrico de $98 \mathrm{st} \mathrm{ha}^{-1} \mathrm{em}$ relação a testemunha, após 4 anos do plantio. Na condução da brotação, a aplicação de $56 \mathrm{tha}^{-1}$ do composto proporcionou um aumento de produtividade de $263 \%$ em relação a testemunha. Entretanto, os autores salientam que essa dose pode não ser economicamente viável. Em comparação com a adubação mineral $\left(210 \mathrm{~kg} \mathrm{ha}^{-1}\right.$ de 10-20-10 + $100 \mathrm{~kg} \mathrm{ha}^{-1}$ FAPS), a aplicação de $21 \mathrm{tha}^{-1}$ do composto proporcionou aumentos de produtividade de 14 e $18 \%$, para a aplicação na entrelinha de plantio e em área total, respectivamente.

Em experimento conduzido por Moro (1994) no município de Casa Branca, SP, onde se utilizou 5, 10, 15, 20 e $25 \mathrm{t} \mathrm{ha}^{-1}$ de cinza de biomassa florestal em Eucalyptus grandis, a maior produção volumétrica foi estimada com a dose de $22,8 \mathrm{tha}^{-1}$, após 79 meses do plantio. A produção máxima de 
$281 \mathrm{~m}^{3} \mathrm{ha}^{-1}$, representou um ganho de produtividade de $46 \%$ em relação a testemunha $\left(193 \mathrm{~m}^{3} \mathrm{ha}^{-1}\right)$. Entretanto, a dose que proporcionou o melhor resultado econômico foi a de $19,6 \mathrm{tha}^{-1}$, com um retorno líquido equivalente a $64 \mathrm{~m}^{3}$ de madeira.

Quando se compara o teor de nutrientes do biossólido em relação a outros resíduos utilizados em plantios florestais é possivel avaliar o seu potencial fertilizante (Tabela 13).

Quando considerado que esses resíduos já vêm sendo utilizados comercialmente em plantios de eucalipto, o potencial de utilização do biossólido em florestas, do ponto de vista nutricional, é promissor.

Tabela 13. Caracterização química média de alguns resíduos utilizados em experimentos de fertilização de povoamentos de eucalipto.

\begin{tabular}{lrcrc}
\hline COMPONENTES & Cinza $^{1}$ & Resíduo celulósico $^{1}$ & Composto orgânico $^{2}$ & Biossólido $^{3}$ \\
\hline PH & 10,00 & 7,50 & 8,00 & 10,15 \\
C.O. (\%) & 4,50 & 3,30 & $53,10^{4}$ & 13,35 \\
N total (\%) & 0,05 & 0,34 & 1,77 & 1,76 \\
P total (\%) & 0,38 & 0,09 & 0,54 & 0,85 \\
K (\%) & 1,59 & 0,07 & 1,07 & 0,08 \\
Ca (\%) & 9,68 & 1,55 & 2,96 & 11,66 \\
Mg total (\%) & 0,93 & 0,09 & 0,48 & 0,43 \\
\hline
\end{tabular}

Fonte: ${ }^{1}$ Adaptado de Moro (1994); ${ }^{2}$ Adaptado de Zen et al. (1994); ${ }^{3}$ Adaptado de Poggiani \& Benedetti (2000).

3 Valor médio, calculado pelo autor, para 9 amostras coletadas entre os meses de julho a dezembro de 1999.

${ }^{4}$ Matéria Orgânica.

C.O.: Carbono Orgânico.

O uso do biossólido como fertilizante em culturas florestais tem sido estudado por diversos autores em diversas partes do mundo. Devido ao caráter experimental desses estudos as doses de aplicação são ainda bastante variadas, e na grande maioria dos casos são limitadas pela alta concentração de nitrogênio no biossólido (Tabela 14). 
Tabela 14. Exemplos de doses de biossólido utilizadas em experimentos de fertilização com espécies florestais.

\begin{tabular}{|c|c|c|}
\hline ESPÉCIE & $\begin{array}{c}\text { DOSE } \\
\left(\mathrm{t} \mathrm{ha}{ }^{-1} \text { em base seca) }\right.\end{array}$ & FONTE \\
\hline $\begin{array}{l}\text { Acer saccharum e } \\
\text { Betula alleghaniensis }\end{array}$ & $\begin{array}{c}(23,1) ;(46,3) \mathrm{e} \\
(92,6)\end{array}$ & Roy \& Couillard (1998) \\
\hline $\begin{array}{l}\text { Populus tremula, P. berolinensis e } \\
\text { Acer negundo }\end{array}$ & $(360)$ e $(720)$ & Gradeckas et al. (1998) \\
\hline Pinus ponderosa & (11) & Zabowski \& Henry (1994) \\
\hline Picea sitchensis & $(13) \mathrm{e}(26)$ & Dutch et al. (1994) \\
\hline Pseudotsuga menziesii & $(47)$ e (142) & Henry et al. (1993) \\
\hline Pinus taeda & (19) & Miegroet et al. (1989) \\
\hline Pinus eldarica & $(67)$ & Phillips et al. (1986) \\
\hline Pinus elliotti & $\begin{array}{l}(20) ;(40) ;(60) \\
(80) \text { e }(100)\end{array}$ & Lutrick et al. (1986) \\
\hline $\begin{array}{l}\text { Pinus taeda, P. echinata e } \\
\text { P. virginiana }\end{array}$ & $(34)$ & McNab \& Berry (1985) \\
\hline Pinus strobus & $(4,8) ;(9,7)$ e $(19,3)$ & Brockway (1983) \\
\hline
\end{tabular}

De modo geral, há um consenso entre os pesquisadores de que os sítios florestais são mais adequados para o uso do biossólido do que os agrícolas, justificado principalmente pelo caráter não alimentício dos produtos dessas culturas. Esses locais podem ser beneficiados de duas formas: (i) pela imediata resposta em crescimento das plantas e (ii) pelo incremento de produtividade a longo prazo (Wang, 1997; Polglase \& Myers, 1995 e Henry et al., 1994).

Polglase \& Myers (1995) e Henry et al. (1994) ressaltam as seguintes razões para que os sitios florestais sejam potenciais candidatos a disposição de biossólido:

a) a produtividade de muitas florestas, limitada pela deficiência especialmente de $N$ e $P$, pode ser recuperada pela fertilização com o biossólido;

b) a maioria dos produtos de origem florestal não se destina à alimentação humana ou animal, o que reduziria os riscos de contaminação na cadeia alimentar; 
c) os solos florestais apresentam propriedades desejáveis para disposição do biossólido, tais como a presença de uma grande proporção de carbono orgânico que imobiliza o nitrogênio disponivel e de uma grande taxa de infiltração de água que minimiza o escorrimento superficial;

d) as espécies florestais apresentam um sistema de raízes perenes muito desenvolvidos horizontal e verticalmente, permitindo que a planta absorva durante $\mathrm{o}$ ano todo os nutrientes disponiveis e diminuindo a perda de nutrientes por lixiviação e/ou erosão;

e) as espécies florestais, geralmente, são mais resistentes aos efeitos fitotóxicos dos metais pesados o que permite a aplicação de doses maiores do que em culturas agrícolas;

f) as áreas florestais são geralmente mais distantes dos centros urbanos do que as agricultáveis e os riscos de contaminação pública e de reclamações quanto ao mau cheiro e aspecto são menores (este aspecto pode se tornar também uma limitação na medida que quanto mais distante das fontes produtoras, maior será o custo com o transporte); e

g) o longo período de cultivo em espécies florestais permite maior flexibilidade quanto à época e intervalo de aplicação.

Deve-se considerar ainda que as atividades silviculturais são na sua maioria mecanizadas, o que reduz ainda mais os riscos de contaminação humana no campo, e que as florestas ocupam extensas áreas contínuas e demandariam grandes quantidades de biossólido.

A fertilização de povoamentos florestais com biossólido tem demonstrado que essa prática proporciona ganhos de produtividade significativos. Harrison et al. (1993) avaliando a aplicação de $47 \mathrm{t} \mathrm{ha}^{-1}$, em base seca, de biossólido em povoamentos jovens de Pseudotsuga menziesii, no Estado de Washington (EUA) encontraram, após 9 anos da aplicação, respostas em altura de 72, 14 e 2\%, para as classes de sítio IV, III e II, respectivamente. A mesma dose aplicada em povoamentos com 65 anos de 
idade resultou em aumentos volumétricos de 65 e 40\%, para povoamentos desbastados e não desbastados, respectivamente, em relação à testemunha.

Harrison et al. (1996), avaliando a aplicação de 19 e 17 t ha $^{-1}$, em base seca, de biossólido em povoamentos de Pseudotsuga menziesii no Estado de Washington (EUA), encontraram incrementos médios de $18 \%$ no DAP (diâmetro a altura do peito), 6,7\% na altura, 32\% na área basal, 39,4\% no volume e $42 \%$ no peso do tronco, em relação à testemunha. Na fertilização de povoamentos da mesma espécie com biossólido, os autores relatam respostas de 2 a $100 \%$ em povoamentos naturais e de até $1.000 \%$ em plantios que receberam altas doses do resíduo.

Polglase \& Myers (1995) avaliando a aplicação de resíduo primário de ETE em povoamentos de várias espécies do gênero Eucalyptus na Austrália, verificaram aos 34 meses de idade respostas diferenciadas entre espécies. As espécies de maior crescimento apresentaram altura média de 9,5 metros e volumes superiores a $50 \mathrm{~m}^{3} \mathrm{ha}^{-1}$, enquanto as outras apresentaram altura média de $8 \mathrm{~m}$ e volumes inferiores a $35 \mathrm{~m}^{3} \mathrm{ha}^{-1}$. Os autores salientaram que as altas taxas de crescimento associadas ao uso de resíduos de ETEs em eucalipto podem afetar a estabilidade e a forma das árvores.

Vários são os fatores que influenciam a resposta das árvores à fertilização com biossólido, dentre os quais destacam-se:

a) ambientais: como chuva, temperatura etc.;

b) produtividade local: em geral, espera-se respostas maiores das culturas em solos mais arenosos e com teores menores de matéria orgânica (Raij, 1998);

c) manejo: por exemplo, desbastes tendem a aumentar a resposta volumétrica dos povoamentos;

d) fisiológicos (inerentes à espécie): respostas positivas podem ser verificadas para a maioria das espécies florestais, entretanto a magnitude varia consideravelmente; e

e) tipo e qualidade do biossólido: resíduos mais estabilizados produzem respostas maiores (Polglase \& Myers, 1995 e Harrison et al., 1993). 
Outro aspecto básico que deve ser considerado na implementação dessa proposta ou de pesquisas correlatas é a maximização dos efeitos benéficos de maneira consistente, de forma segura e com o mínimo custo. Devido ao seu alto teor de umidade e as altas doses empregadas, os custos de transporte e de aplicação de resíduos são normalmente maiores do que os de um fertilizante mineral equivalente nutricionalmente. Kempton \& Cusack (1999) atribuem ao alto teor de umidade no biossólido o alto custo da estabilização, do transporte e do seu uso como fertilizante.

\subsection{Estratégias de manejo do biossólido para uso como fertilizante}

Para Kempton \& Cusack (1999) o desenvolvimento de uma estratégia completa de manejo para o biossólido deve considerar os seguintes aspectos:

a) o mercado: estabelecer mercado para a destinação sustentável do biossólido. O mercado para o biossólido depende das suas características físico-químicas e biológicas e dos custos associados com a produção, transporte e monitoramento;

b) o processo: estabelecer um processo de estabilização satisfatório para produzir o requerido produto (digestão aeróbica ou anaeróbica, uso de cal, secagem térmica e "peletização", compostagem e a combinação desses, são alguns exemplos);

c) o produto: adequar as características do produto às necessidades do mercado. Na China, por exemplo, é produzido um fertilizante combinando o biossólido e fertilizantes químicos tradicionais (Wang, 1997). Essa estratégia pode aumentar o valor do produto final.

As definição das necessidades do mercado para o biossólido devem ser baseadas em:

a) informações relacionadas à cultura e ao solo; 
b) características físicas do produto requerido (embalado, à granel, "peletizado" ou líquido);

c) método de aplicação: aplicado superficialmente, ou sub-superficialmente. Avaliar a necessidade de desenvolvimento de equipamento para aplicação.

d) transporte: distância do mercado consumidor, possibilidade de transporte à granel, necessidade de transporte específico. Avaliar a possibilidade de aproveitamento de carga de outros produtos na ida ou na volta.

e) taxas de aplicação: toneladas secas por hectare, definida pelas características da cultura, do solo e pelos teores de contaminantes;

f) valor comercial do produto e de produtos semelhantes (esterco, composto etc.); e

g) custos de aplicação e de monitoramento (por tonelada seca).

Segundo Kempton \& Cusack (1999), geralmente as estratégias de manejo do biossólido são baseadas apenas no processo (líquido, em tortas, compostado, estabilizado com cal, secagem térmica ou "peletizado").

A SABESP estuda a possibilidade de implantação de Centrais de Secagem Térmicas (CST), para as ETEs de Barueri e São Miguel na RMSP (Tsutya, 2000). A secagem poderia reduzir a umidade no biossólido, que é atualmente de aproximadamente $60 \%$, para 5 a $10 \%$. Esta estratégia objetiva viabilizar o uso agrícola do biossólido pela diminuição dos custos de transporte e pela eliminação de organismos patogênicos. Para Moro (1994), por exemplo, a viabilização econômica do uso de resíduos em plantios de eucalipto foi possivel pela adoção de medidas de redução de volume transportado, aproveitamento do retorno de transporte de madeira para o transporte de resíduo e terceirização do transporte e aplicação.

O desenvolvimento de sistemas eficientes de aplicação e transporte do biossólido também contribuiria para diminuir os custos suportados pelos produtores quando da fertilização. No Estado de Washington (EUA), por exemplo, o custo de fertilização de florestas com biossólido se situa entre 80 a 100 dólares por hectare, por tonelada (Harrison et al., 1996). Entretanto, esta 
estratégia requer altos investimentos em pesquisa. Nos EUA, os equipamentos para a aplicação de biossólido em florestas foram desenvolvidos ao longo de 20 anos de pesquisa, com um considerável aporte de recursos financeiros e materiais (Harrison, et al., 1996 e McFadden \& Shiess, 1989). O desenvolvimento de estratégias para a redução dos custos de fertilização de florestas com biossólido pode representar um alto investimento que é, entretanto, justificável pois viabiliza economicamente a alternativa para o produtor florestal (Kempton \& Cusack, 1999).

Uma alternativa promissora no Brasil é a fertilização de povoamentos florestais implantados com espécies de rápido crescimento, especialmente com eucaliptos, normalmente voltados para a produção de celulose, madeira para energia, serraria, postes e mourões. Como exemplo a Figura 3 apresenta a evolução da área reflorestada anualmente com eucaliptos no Brasil. O aumento da área plantada deveu-se principalmente à expansão do setor de celulose e papel, que durante os anos 80 apresentou taxas de crescimento médias anuais de 4,7 a 4,9\% (Kronka et al., 1993). A produção de celulose que em 1970 foi de 386.000 toneladas passou para 1.250 .000 em 1992 , representado um aumento de $324 \%$ no período. Mantida a tendência de aumento verificada nos últimos anos e considerando que esses plantios são manejados intensivamente, o potencial de consumo do biossólido por esse gênero é promissor. 


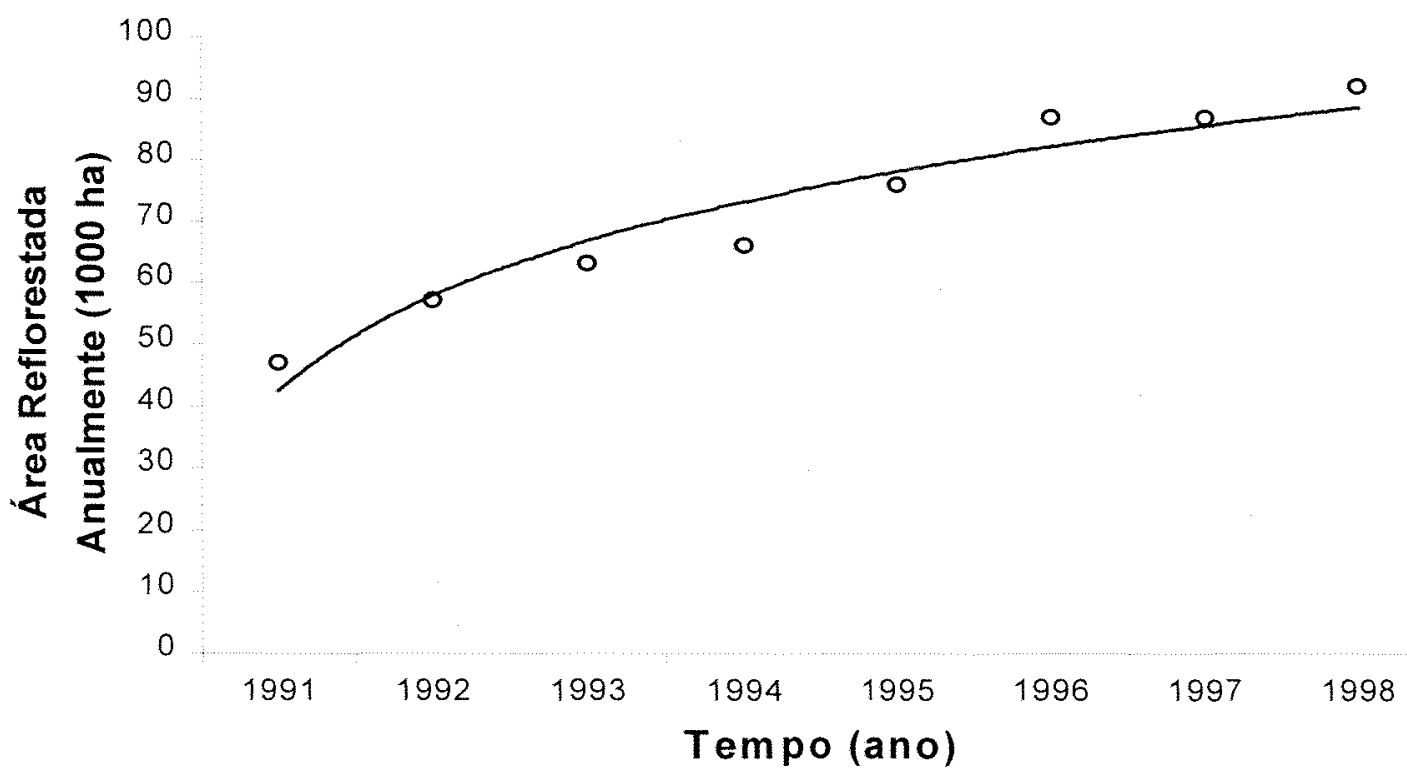

Figura 3 - Evolução da área reflorestada anualmente no Brasil com espécies de eucalipto.

Fonte: Adaptado de Associação Brasileira de Celulose e Papel (1998)

Normalmente as pesquisas de fertilização com o biossólido são voltadas para a minimização dos potenciais riscos dessa prática. 0 incentivo a pesquisas voltadas, também, para o aumento da produtividade de espécies florestais contribuiria para a melhor aceitação do biossólido pelos produtores. Nesse contexto, é válida a proposta de que ao invés de procurar um mercado para um material de baixa qualidade e pouca aceitação, é mais interessante adequar o produto às necessidades do mercado.

\subsection{Determinação dos niveis economicamente ótimos de fertilização}

A fertilização de florestas é prática comum em empresas florestais que buscam altas produtividades. Um dos principais aspectos que deve ser considerado durante a análise da necessidade de fertilização em florestas é a avaliação econômica baseada na comparação entre os eventuais retornos futuros e o investimento atual na fertilização. Gomes \& Garcia (1990), destacam a importância dessa análise em um estudo econômico de 
experimentos de fertilização, justificando que do contrário poderiam ser recomendas práticas culturais ruinosas, tendo em vista o considerável volume de recursos financeiros envolvidos.

As doses de fertilizante aplicadas e a futura resposta em volume são informações imprescindiveis para a correta avaliação de viabilidade (Ferreira, 1983), Outro parâmetro a ser considerado é a área adicional que seria necessária para se obter a mesma produção final caso não fosse implementada a adubação. Esse aumento na área resultaria em maiores investimentos com a própria aquisição de terras, preparo do solo, manutenção, mão-de-obra etc. (Instituto de Pesquisas e Estudos Florestais, 1976). O aumento em volume como resposta à fertilização permite que se plante uma área menor e se obtenha o mesmo nivel de produção. Ferreira (1983), analisando o retorno financeiro da fertilização mineral em diferentes espécies de eucaliptos, verificou que a fertilização não foi economicamente viável (critério do VPL) quando considerada apenas a receita adicional da madeira resultante da adubação. Entretanto, para obtenção do mesmo nivel de produção total, resultado inverso foi obtido quando se considerou a economia obtida com a redução na área total provocada pela fertilização.

A correta determinação dos níveis economicamente ótimos a partir de ensaios de fertilização utiliza-se da análise de superfícies de resposta ajustadas a partir de técnicas de regressão estatística que correlacionam níveis de fertilização e volumes de madeira produzida (Gomes \& Garcia, 1990). Essa relação deve apresentar duas importantes propriedades:

i) continuidade - ser válida para qualquer nível de fertilização dentro do intervalo significativo de análise; e

ii) atendimento à leí dos rendimentos marginais decrescentes - a taxa de resposta ao aumento dos niveis de fertilização é crescente para níveis iniciais, decrescente em seguida, nula no ponto de máxima produção e eventualmente negativa para as doses mais altas (Rodriguez et al., $1996 \mathrm{e}$ Berger, 1975). 
No caso dos ensaios de fertilização é de se esperar que, permanecendo constantes as quantidades dos demais recursos, essas duas condições prevaleçam e que os aumentos nos níveis de fertilização elevem a produção até um nível máximo, a partir do qual a produção não responda mais ou até mostre respostas inferiores.

\subsection{Matemática financeira}

Uma importante variável em avaliações financeiras é a taxa de juros, ou de retorno, usada na análise (taxa mínima aceitável) que expressa a variação temporal do valor do fluxo de receitas e custos considerados no projeto. A taxa de juros usada em critérios de avaliação de projetos segue os princípios de capitalização composta e deve refletir a taxa mínima de retorno aceitável do investidor.

A mais básica fórmula de juros compostos pode ser apresentada das seguintes formas (Klemperer, 1996, p.114):

$$
\begin{aligned}
& V_{0}=\frac{V_{n}}{(1+i)^{n}}, \text { ou } \\
& V_{n}=V_{0}(1+i)^{n}
\end{aligned}
$$

em que:

$\mathrm{V}_{0}=$ valor presente (valor inicial);

$\mathrm{V}_{\mathrm{n}}=$ valor futuro depois de n períodos de capitalização;

$\mathrm{i}=$ taxa de juros; $\mathrm{e}$

$\mathrm{n}=$ número de períodos de capitalização ou de descapitalização dos juros. 
Essas expressões formam a base para o desenvolvimento de importantes critérios de avaliação financeira de projetos, como por exemplo o Valor Presente Líquido (VPL) e o Valor Esperado da Terra (VET).

Todo projeto de investimento apresenta uma dimensão temporal, e quando necessário será representado de forma gráfica, com o tempo representado ao longo de um eixo horizontal e, convencionalmente, as receitas acima da linha, com o sinal positivo $(+)$ e os custos abaixo, com o sinal negativo $(-)$.

\subsection{Critérios de avaliação financeira}

Existem duas formas básicas de avaliar projetos de investimentos. A primeira é a comparação de dois ou mais projetos, para a escolha do melhor. Outra, é a análise individual de cada projeto, para avaliação do potencial retorno financeiro. Esta última envolve a decisão entre investir ou não em um determinado projeto, de acordo com o seu desempenho financeiro.

Para a classificação de diferentes projetos em termos do resultado econômico ou do potencial de retorno, um critério bastante útil é o Valor Presente Líquido (VPL). O VPL é definido como o valor presente das receitas subtraído do valor presente dos custos, e pode ser calculado através da seguinte equação:

$$
V P L=\sum_{t=0}^{n}\left[\frac{R_{t}}{(1+i)^{t}}\right]-\sum_{t=0}^{n}\left[\frac{C_{t}}{(1+i)^{t}}\right]
$$

em que:

$\mathrm{R}_{\mathrm{t}}=$ receita no tempo $\mathrm{t}$;

$\mathrm{C}_{\mathrm{t}}=$ custo no tempo $\mathrm{t}_{\text {; }}$

$\mathrm{i}$ = taxa mínima aceitável de retorno; e

$\mathrm{n}=$ horizonte de duração do investimento. 
Por esse critério o projeto será economicamente viável quando apresentar valores positivos para o VPL. No caso de classificação de diferentes projetos de investimento com horizontes iguais, mais atraente será o projeto quanto maior for o VPL. Uma limitação para o uso do VPL é que sua utilização só é possível quando os fluxos de caixa dos diferentes projetos sendo analisados tenham a mesma duração.

Outro critério de avaliação financeira de projetos é a Taxa Interna de Retorno (TIR). A TIR é definida como a taxa de juros que torna igual o valor presente das receitas e o valor presente dos custos, isto é, aquela que faz com que o VPL seja nulo. A expressão para o cálculo da TIR é a seguinte:

$$
\sum_{t=0}^{n}\left[\frac{R_{t}}{(1+\text { TIR })^{t}}\right]-\sum_{t=0}^{n}\left[\frac{C_{t}}{(1+\text { TIR })^{t}}\right]=0
$$

Quanto maior o valor da TIR mais atraente é o projeto. Uma desvantagem dessa técnica pode ser observada quando o projeto apresenta fluxo de caixa com inversão de sinais nas receitas anuais líquidas. Neste caso, podem ser obtidas duas ou mais TIRs para um mesmo projeto (Klemperer, 1996 e Clutter et al., 1983).

O Valor Esperado da Terra (VET) ou fórmula de Faustmann (Faustmann, $1849^{13}$ citado por Klemperer, 1996) é um critério econômico bastante utilizado na área florestal. O VET nada mais é do que o valor presente de uma série periódica perpétua de VFLs (Valor Futuro Líquido). Neste caso considera-se a repetição infinita do ciclo florestal e consequentemente do seu respectivo fluxo de caixa. Este critério de avaliação é muito útil na área

13 FAUSTMANN, M. Berechnung des Werthes welchen Waldboden sowie noch nicht haubare Holzbestände für die Waldwirtschaft besitzen. Allgemeine Forst und Jagd-Zeitung. n.25, p.441-455, 1849. (English translation in Linnard, W. and M. Gane Martin Faustmann and the evaluation of discounted cash flow. Commonwealth Forestry Institute Paper 42, 1968). 
florestal pois permite a comparação entre projetos com diferentes horizontes de planejamento. A expressão geral do VET é a seguinte:

$\mathrm{VET}=\frac{\mathrm{RL}_{\mathrm{t}}}{\left[(1+\mathrm{i})^{\mathrm{t}}-1\right]}$

em que:

VET = Valor Esperado da Terra;

$\mathrm{RL}_{\mathrm{t}}=$ Receita Líquida capitalizada ao fim de $t$ anos;

$t=$ duração, em anos, de cada ciclo produtivo da floresta; e $i=$ taxa anual de juros.

Através deste critério um projeto de investimento é viável economicamente quando apresentar valores positivos para o VET. Em se tratando de dois ou mais projetos o melhor será o que apresentar maior VET. 


\section{METODOLOGIA}

\subsection{Demanda potencial de biossólido em povoamentos de eucalipto no entorno da ETE de Barueri}

\subsubsection{Levantamento da área de eucaliptos no entorno da ETE de Barueri}

A fonte de dados utilizada no presente trabalho foi o Inventário Florestal do Estado de São Paulo editado pelo Instituto Florestal do Estado de São Paulo (IF) (Kronka et al., 1993). As informações do inventário florestal do Estado, na escala de 1:250.000, foram disponibilizados pelo IF na forma digital. A partir dessa base de dados, foram estabelecidos círculos concêntricos com intervalos de 20 quilômetros, tendo como centro a ETE de Barueri, e encontrada a área com reflorestamentos de eucalipto a cada acréscimo de 20 quilômetros de raio, até uma distância máxima de $200 \mathrm{~km}$ (Figura 4).

Os dados foram processados com o auxílio dos programas "IDRISI" e "ArcView", os quais são utilizados em Sistemas de Informações Geográficas (SIG). Esta estratégia permitiu automatizar a obtenção das informações necessárias para o diagnóstico do potencial de uso do biossólido em povoamentos de eucalipto. 


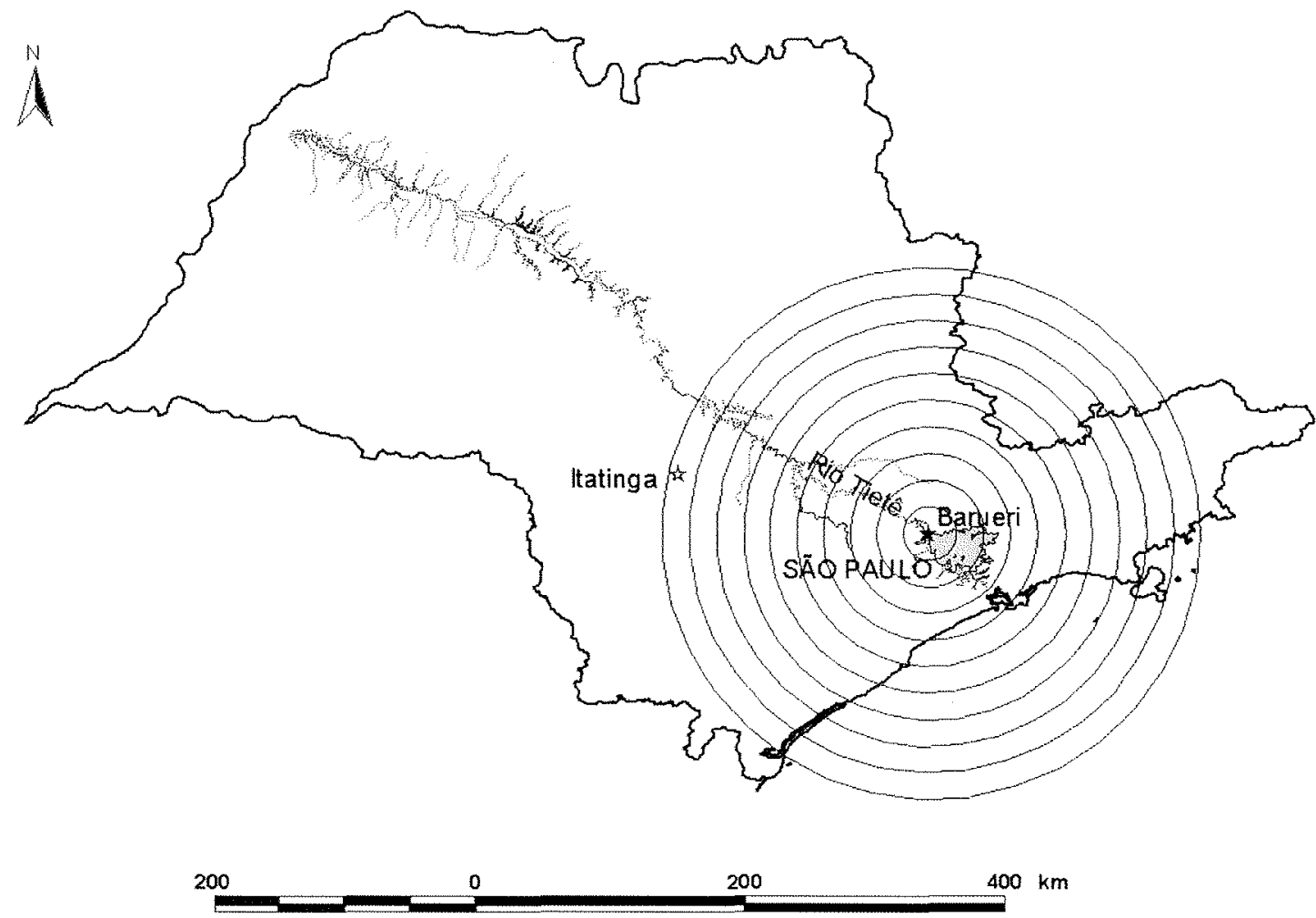

Figura 4 - Representação esquemática da metodologia para diagnóstico do potencial de uso do biossólido da ETE de Barueri em povoamentos de eucalipto do Estado de São Paulo.

\subsubsection{Seleção da área potencialmente disponível anualmente para fertilização com biossólido}

Para estimativa da área disponível anualmente com povoamentos de eucalipto são necessárias informações que não constavam na base de dados disponibilizada pelo IF, que são: (i) o sistema de manejo e (ii) a distribuição de classes de idade desses povoamentos. O sistema de manejo utilizado nas florestas varia de acordo com as condições climáticas, a espécie plantada, as facilidades operacionais das empresas florestais, dentre outros fatores.

$\mathrm{Na}$ falta das informações necessárias para o cálculo da área anual potencialmente disponível para fertilização com biossólido, foram consideradas as seguintes pressuposições: 
a) ciclo de produção para o eucalipto de sete anos;

b) distribuição uniforme de área entre classes de idade. Portanto, um sétimo da área total plantada com eucalipto encontra-se no primeiro ano de desenvolvimento; e

c) a aplicação do biossólido em eucalipto seria feita apenas uma vez no primeiro ano de desenvolvimento.

A base de dados utilizada não permitiu a seleção de áreas aptas a disposição do biossólido observando os critérios de localização propostos na norma da CETESB P 4.230 - jan./99 (seção 2.3.2). Na impossibilidade da determinação das áreas que deveriam ser excluídas no cálculo do potencial de uso, foram simuladas reduções percentuais na área disponivel anualmente para fertilização. Para os cenários assim criados foram diagnosticados o potencial de consumo de biossólido nos povoamentos de eucalipto simulando diferentes produções na ETE e taxas de aplicação no campo.

\subsection{Produção mínima de madeira para viabilização econômica da fertilização de eucaliptos com biossólido}

O estudo de viabilidade econômica proposto neste trabalho baseia-se exclusivamente na análise do fluxo de receitas e custos gerados pelo uso do biossólido como fertilizante.

Os custos e receitas associados ao uso do biossólido como fertilizante são importantes variáveis para a análise da viabilidade econômica dessa alternativa de destinação. A determinação de valores adequados para esses itens é um fator importante para uma correta avaliação econômica. Os custos de fertilização considerados neste estudo são o de transporte e o de distribuição do biossólido no campo. As receitas provenientes da fertilização de povoamentos florestais com o biossólido são geradas pelo aumento de produtividade advindo dessa prática. Em ensaios de fertilização, a 
produtividade normalmente é expressa por um modelo matemático que correlaciona ganhos de produtividade e niveis de fertilizante adicionados. Essa relação é geralmente denominada curva de resposta.

A seguir são determinados os valores que irão compor os fluxos de caixa usados na avaliação.

\subsubsection{Curva de resposta à aplicação de biossólido}

A curva de resposta das espécies florestais em função da aplicação de biossólido define os volumes de madeira esperados e, consequentemente, as receitas que podem ser proporcionadas por essa prática. Entretanto, não existem ainda curvas de reposta completas para a fertilização de eucalipto com biossólido. Essa limitação foi contornada com o estabelecimento de diferentes cenários (intervalos) para importantes parâmetros no processo. Considerando diferentes taxas de juros, custos da fertilização com o biossólido e ciclos de produção para o eucalipto foram criados cenários de simulação para os quais calculou-se o parâmetro de decisão "nível mínimo de resposta (NMR)".

O NMR define, para cada situação simulada, o acréscimo na produção que seria necessário para justificar economicamente o emprego do biossólido como fertilizante.

Deve-se considerar que se o custo da fertilização fosse nulo, a recomendação da dose que resulta na maior produção média maximizaria a eficiência técnica (determinação da dose volumetricamente ótima). Entretanto, é comum existirem custos associados a esses fatores de produção, e a análise procurará determinar os níveis que maximizam a eficiência econômica (determinação da dose economicamente ótima). 
3.2.1.1 Desenvolvimento das expressões para calculo do NMR

Assume-se, neste estudo, que o tomador de decisão torna-se indiferente quanto ao uso ou não do biossólido como fertilizante quando na sua análise o VPL resultar nulo. Nesse caso, o investimento com a fertilização é remunerado apenas pela taxa mínima aceitável de retorno considerada na avaliação do investimento.

Para o desenvolvimento da equação de cálculo do NMR foi utilizada a eq. (8) que capitaliza custos e receitas até o final do ciclo florestal. A expressão para o NMR é obtida igualando-se os custos e receitas no final do ciclo (VPL=0).

A seguir são apresentadas as representações gráficas do investimento e as equações para NMR, considerando (i) a aplicação do biossólido apenas no plantio, com ciclo de 7 anos; e (ii) aplicação no plantio e reaplicação na condução da brotação, com rotações de 7 anos e diferentes ciclos de produção. Quando considerado que a floresta apresenta ciclo de duas ou mais rotações assumiu-se que o NMR nas diferentes rotações são iguais.

a) Aplicação apenas no plantio com uma rotação por ciclo:

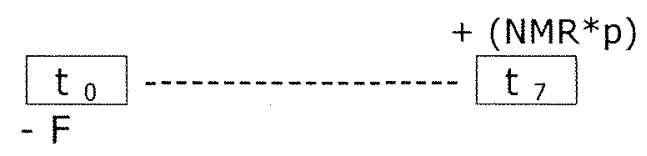

$\mathrm{NMR}=\frac{\mathrm{F}(1+\mathrm{i})^{7}}{\mathrm{p}}$ 
b) Aplicação apenas no plantio com duas rotações por ciclo:

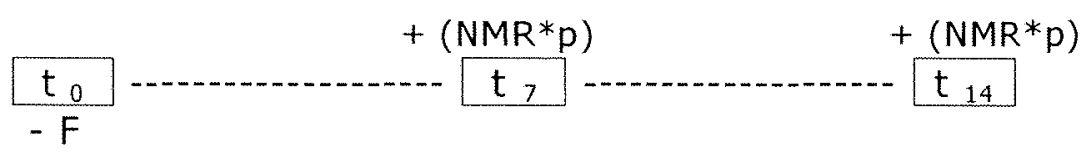

$\mathrm{NMR}=\frac{\mathrm{F}(1+\mathrm{i})^{14}}{\mathrm{p}\left[(1+\mathrm{i})^{7}+1\right]}$

c) Aplicação apenas no plantio com três rotações por ciclo

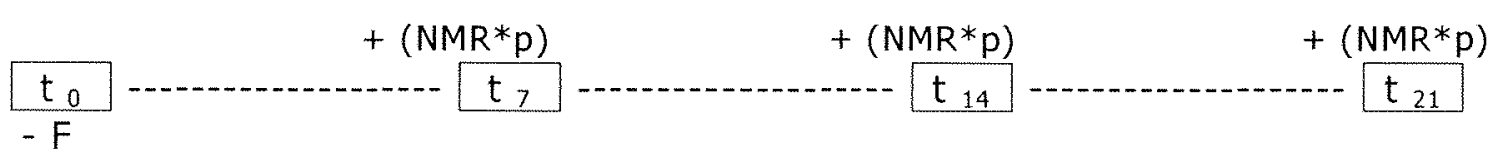

$\mathrm{NMR}=\frac{\mathrm{F}(1+\mathrm{i})^{21}}{\mathrm{p}\left[(1+\mathrm{i})^{14}+(1+\mathrm{i})^{7}+1\right]}$

onde:

NMR $=$ Nível Mínimo de Resposta $\left(\right.$ st ha $\left.{ }^{-1}\right)$;

$\mathrm{F}=$ custo da fertilização, aqui considerado como o de transporte e distribuição no campo ( $\left.R \$ h^{-1}\right)$;

$\mathrm{i}=$ taxa mínima aceitável de retorno (decimal);

$\mathrm{p}=$ preço da madeira $\left(\mathrm{R} \$ \mathrm{st} \mathrm{H}^{-1}\right) ; \mathrm{e}$

$t_{\text {ano }}=$ instante de realização de um custo ou receita.

d) Aplicação no plantio e reaplicação na condução da brotação

No caso da aplicação do biossólido no plantio e reaplicação na condução da brotação a expressão do NMR se torna a eq. (9). Para exemplificar será considerado o ciclo com duas rotações. Neste caso, a representação gráfica e a expressão para o NMR são apresentados a seguir. 


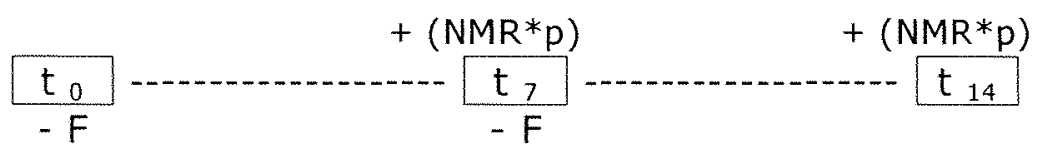

$\mathrm{NMR}=\frac{\mathrm{F}\left[(1+\mathrm{i})^{14}+(1+\mathrm{i})^{7}\right]}{\mathrm{p}\left[(1+\mathrm{i})^{7}+1\right]}$

Entretanto, a expressão acima pode ser reescrita da seguinte forma:

$\mathrm{NMR}=\frac{\mathrm{F}\left\{(1+\mathrm{i})^{7}\left[(1+\mathrm{i})^{7}+1\right]\right\}}{\mathrm{p}\left[(1+\mathrm{i})^{7}+1\right]}$

Realizando-se as simplificações cabíveis, tem-se:

$\mathrm{NMR}=\frac{\mathrm{F}(1+\mathrm{i})^{7}}{\mathrm{p}}$

resultando novamente na eq. (9).

O cáculo do custo de transporte e distribuição do biossólido nos sítios florestais ("F", custo de fertilização), em $R \$ h^{-1}$, foi expresso da seguinte forma:

$$
F=\left(\frac{D S .100}{100-U}\right)(D T . C F+C A)
$$

onde:

DS = Dose de aplicação, em base seca $\left(\mathrm{t} \mathrm{ha}^{-1}\right)$;

$\mathrm{U}=$ Teor de umidade do biossólido (\%);

DT = Distância de Transporte $(\mathrm{km})$;

$\mathrm{CF}=$ Custo de frete $\left(\mathrm{R} \$ \mathrm{t}^{-1} \mathrm{~km}^{-1}\right) ; \mathrm{e}$ 
$C A=$ Custo de aplicação no campo $\left(R \$ t^{-1}\right)$.

O NMR foi calculado considerando-se diferentes níveis para as variáveis em questão. Esse procedimento permitiu a simulação de diferentes cenários para a fertilização de eucaliptos com o biossólido.

\subsubsection{Custos associados ao uso do biossólido como fertilizante}

O biossólido não é uma carga comumente transportada pelas rodovias brasileiras. Atualmente, transporte dessa natureza vem sendo realizado periodicamente na rota que liga a ETE de Barueri, SP, ao aterro sanitário localizado ao lado da Rodovia dos Bandeirantes. Entretanto, os valores de custo de frete adotados para esse trajeto não necessariamente refletem os esperados para rotas diferentes. Para a estimativa do custo de frete utilizado no presente trabalho optou-se por adotar aqueles praticados para o frete de calcário à granel, transportado em caminhões com recursos semelhantes aos utilizados para o transporte do biossólido.

A coleta mensal dos valores para custo de frete foi realizada através do acompanhamento do custo do frete para calcário a granel, utilizando-se o periódico especializado "SISTEMA DE INFORMAÇÕES DE FRETES PARA CARGAS AGRÍCOLAS (SIFRECA ${ }^{14}$ )", divulgado pelo Departamento de Economia e Sociologia Rural da ESALQ/USP. Este procedimento permitiu, também, avaliar tendências de variação nesse custo ao longo do periodo considerado. Para a obtenção dos valores de custo de frete nas diferentes distâncias foram ajustadas equações aos dados coletados.

A distribuição do biossólido no campo influencia a viabilidade econômica do seu uso na medida em que agrega custos significativos à essa atividade. Normalmente são adicionadas grandes quantidades de biossólido por hectare, necessitando-se de um sistema racional e otimizado de distribuição. De modo geral, quanto mais eficiente for o sistema de

\footnotetext{
${ }^{14}$ Fonte: http://sifreca.esalq.usp.br
} 
distribuição empregado menores serão os custos. No Brasil não existem equipamentos especializados para a distribuição de biossólido, como nos EUA por exemplo. Como valor aproximado para este custo foi utilizado o da distribuição de composto de resíduos urbanos que já vem sendo utilizado comercialmente em povoamentos de eucalipto no Estado de São Paulo.

A umidade do biossólido influencia os custos de transporte $\mathrm{e}$ distribuição. Normalmente são recomendadas doses em base seca, apesar do transporte e distribuição serem realizados em base úmida. O teor de umidade para o biossólido considerado no presente estudo foi de $60 \%$, semelhante à média para os valores obtidos em amostras de biossólido oriundas da ETE de Barueri (Santos \& Tsutya, 1997).

\subsection{Taxa máxima de aplicação de biossólido nos povoamentos florestais}

Os custos da fertilização de povoamentos de eucalipto com biossólido é diretamente proporcional à dose utilizada. Normalmente os custos aumentam com o aumento da dose, permanecendo as outras variáveis constantes. A dose máxima de biossólido utilizada, via simulação, neste trabalho baseou-se na obtida pelo teor de nitrogênio recomendado para a cultura e no disponível no biossólido, como proposto pela norma da CETESB (seção 2.3.2). Observando o valor como limite superior, foram gerados deferentes cenários considerando diferentes doses de aplicação.

Os níveis de produção de biossólido na ETE de Barueri considerados neste trabalho foram de 150, 250 e $350 \mathrm{t} \mathrm{dia}^{-1}$, em base seca. Estas produções baseiam-se na produção atual e estimativas de produção do resíduo na ETE de Barueri apresentadas na Figura 2. 


\section{RESUltados E discussão}

\subsection{Demanda potencial de biossólido em povoamentos de eucalipto no entorno da ETE de Barueri}

As áreas com povoamentos de eucalipto encontradas a cada acréscimo de 20 quilômetros no raio com centro na ETE de Barueri são apresentadas na Tabela 15 .

Tabela 15. Área reflorestada com eucaliptos a diferentes raios de distância tendo como centro a ETE de Barueri.

\begin{tabular}{|c|c|c|c|c|}
\hline \multirow{3}{*}{$\frac{\text { RAIO }}{\mathrm{km}}$} & \multicolumn{4}{|c|}{ ÁREA REFLORESTADA } \\
\hline & \multicolumn{2}{|c|}{ 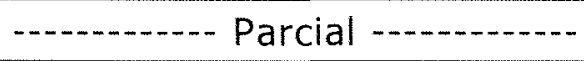 } & \multicolumn{2}{|c|}{............. Acumulada -...... } \\
\hline & ha & $\%$ & ha & $\%$ \\
\hline 0 a 20 & 17.351 & 4 & 17.351 & 4 \\
\hline 20 a 40 & 13.084 & 3 & 30.435 & 7 \\
\hline 40 a 60 & 24.951 & 6 & 55.386 & 13 \\
\hline 60 a 80 & 54.453 & 13 & 109.839 & 25 \\
\hline 80 a 100 & 41.231 & 10 & 151.070 & 35 \\
\hline 100 a 120 & 46.891 & 11 & 197.961 & 46 \\
\hline 120 a 140 & 39.019 & 9 & 236.980 & 55 \\
\hline 140 a 160 & 60.691 & 14 & 297.671 & 69 \\
\hline 160 a 180 & 70.296 & 16 & 367.967 & 85 \\
\hline 180 a 200 & 63.151 & 15 & 431.118 & 100 \\
\hline Total & 431.118 & 100 & & \\
\hline
\end{tabular}

Fonte: Resultado de pesquisa.

O estudo resultou em um total de 431.118 hectares de reflorestamentos de eucalipto em um raio de até 200 quilômetros da ETE. Esse 
valor representou aproximadamente $71 \%$ da área total coberta com eucalipto no Estado de São Paulo, no ano de 1993 (Kronka et al., 1993).

A adoção das considerações listadas na seção 3.1 .2 para cálculo da área anual efetivamente disponível para a disposição do biossólido resulta em uma acentuada redução nesses valores (Tabela 16).

Tabela 16. Área de eucalipto disponível anualmente para a disposição do biossólido a diferentes raios de distância da ETE de Barueri.

\begin{tabular}{|c|c|c|c|c|}
\hline \multirow{3}{*}{$\begin{array}{c}\text { RAIO } \\
\text { km }\end{array}$} & \multicolumn{4}{|c|}{ ÁREA REFLORESTADA } \\
\hline & \multicolumn{2}{|c|}{ 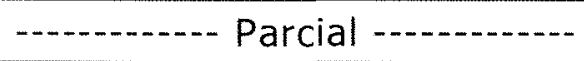 } & \multicolumn{2}{|c|}{-..-- Acumulada -...-... } \\
\hline & ha & $\%$ & ha & $\%$ \\
\hline 0 a 20 & 2.479 & 4 & 2.479 & 4 \\
\hline 20 a 40 & 1.869 & 3 & 4.348 & 7 \\
\hline 40 a 60 & 3.564 & 6 & 7.912 & 13 \\
\hline 60 a 80 & 7.779 & 13 & 15.691 & 25 \\
\hline 80 a 100 & 5.890 & 10 & 21.581 & 35 \\
\hline 100 a 120 & 6.699 & 11 & 28.280 & 46 \\
\hline 120 a 140 & 5.574 & 9 & 33.854 & 55 \\
\hline 140 a 160 & 8.670 & 14 & 42.524 & 69 \\
\hline 160 a 180 & 10.042 & 16 & 52.567 & 85 \\
\hline 180 a 200 & 9.022 & 15 & 61.588 & 100 \\
\hline Total & 61.588 & 100 & & \\
\hline
\end{tabular}

Fonte: Adaptado da Tabela 14.

A taxa máxima de aplicação tomada como referência para este trabalho é determinada a seguir.

Para o cálculo do nitrogênio disponível no biossólido, utilizando-se a eq. (3) proposta pela CETESB (seção 3.3), foram considerados os intervalos de confiança apresentados na Tabela 17.

Considerando-se a combinação da maior taxa de nitrogênio recomenda pelo Boletim 100 (60 kg ha-1 para eucalipto (Gonçalves et al., 1996, p.256)) e do menor valor obtido para o nitrogênio disponível no biossólido, chega-se a uma taxa máxima de aplicação de biossólido de $28 \mathrm{tha}^{-1}$, em base seca. Para 
efeito deste trabalho, essa taxa máxima de aplicação de biossólido foi arredondada para $30 \mathrm{t} \mathrm{ha}^{-1}$, em base seca.

Tabela 17. Concentração de algumas formas nitrogenadas em amostras de biossólido da ETE de Barueri.

\begin{tabular}{ccccc}
\hline Data de coleta & \multicolumn{4}{c}{ Concentração $\left(\mathrm{mg} \mathrm{kg}^{-1}\right.$ em base seca) } \\
\cline { 2 - 5 } da amostra & $\mathrm{N}$ amoniacal & N Kjeldahl & $\mathrm{N}$ nitrato & $\mathrm{N}$ nitrito \\
\hline $16 / 07 / 99$ & 1.210 & 25.707 & 8,3 & 2,0 \\
$20 / 08 / 99$ & 202 & 21.999 & ND & ND \\
$10 / 09 / 99$ & 240 & 8.799 & ND & 0,4 \\
$24 / 09 / 99$ & 1.034 & 9.036 & ND & ND \\
$14 / 10 / 99$ & 1.478 & 7.654 & ND & ND \\
$25 / 10 / 99$ & 628 & 3.954 & ND & 0,6 \\
$10 / 11 / 99$ & 491 & 26.151 & ND & ND \\
$25 / 11 / 99$ & 1.349 & 23.231 & ND & 1,7 \\
$27 / 12 / 99$ & 2.190 & 31.915 & ND & ND \\
\hline Média $^{* *}$ & 980 & 17.605 & 8,3 & 1,2 \\
IC $^{* *}( \pm)$ & 503 & 7.833 & - & 1,3 \\
\hline
\end{tabular}

Fonte: Adaptado de Poggiani \& Benedetti (2000).

ND: Não detectado pelo método analítico empregado.

IC: Intervalo de Confiança da média a $95 \%$.

** Parâmetros calculados pelo autor, considerando apenas os valores numéricos.

Considerando diferentes produções de biossólido na ETE de Barueri, diferentes taxas de aplicação do biossólido no campo e quatro percentuais de redução na área anualmente disponível para fertilização, a Tabela 18 apresenta diferentes cenários para o consumo de biossólido nos povoamentos de eucalipto no entorno da ETE de Barueri.

O intervalo de variação no raio de consumo do biossólido da ETE de Barueri em povoamentos de eucalipto do seu entorno varia de 15 a $178 \mathrm{~km}$. Essas distâncias refletem a combinação da menor produção com a maior dose (150 t dia ${ }^{-1}$ e $30 \mathrm{t} \mathrm{ha}^{-1}$ ) e da maior produção com a menor dose $\left(350 \mathrm{t} \mathrm{dia}^{-1} \mathrm{e}\right.$ $10 \mathrm{tha}^{-1}$ ) 
Tabela 18. Demanda potencial de biossólido em povoamentos de eucalipto considerando diferentes produções de biossólido na ETE de Barueri, doses de aplicação no campo e percentuais de redução na área disponivel anualmente.

\begin{tabular}{|c|c|c|c|c|c|c|}
\hline \multirow{3}{*}{$\begin{array}{l}{ }^{1} \text { Produção } \\
\text { diária de } \\
\text { biossólido na } \\
\text { ETE }\end{array}$} & \multirow{3}{*}{$\begin{array}{c}{ }^{1} \text { Dose de } \\
\text { aplicação de } \\
\text { biossólido no } \\
\text { campo }\end{array}$} & \multirow{3}{*}{$\begin{array}{l}\text { ª́rea necessária para } \\
\text { consumir a produção } \\
\text { anual de biossólido }\end{array}$} & \multicolumn{4}{|c|}{ Disponibilidade anual de área } \\
\hline & & & $100 \%$ & $75 \%$ & $50 \%$ & $25 \%$ \\
\hline & & & \multicolumn{4}{|c|}{${ }^{3}$ Raio de consumo } \\
\hline $\mathrm{tdia}^{-1}$ & $\mathrm{tha}^{-1}$ & ha $a n o^{-1}$ & \multicolumn{4}{|c|}{ - km - - } \\
\hline 150 & 10 & 5.475 & 47 & 57 & 68 & 101 \\
\hline 150 & 20 & 2.738 & 23 & 33 & 47 & 68 \\
\hline 150 & 30 & 1.825 & 15 & 20 & 33 & 57 \\
\hline 250 & 10 & 9.125 & 64 & 71 & 89 & 147 \\
\hline 250 & 20 & 4.563 & 42 & 50 & 64 & 89 \\
\hline 250 & 30 & 3.042 & 27 & 37 & 50 & 71 \\
\hline 350 & 10 & 12.775 & 73 & 85 & 112 & 178 \\
\hline 350 & 20 & 6.388 & 52 & 62 & 73 & 112 \\
\hline 350 & 30 & 4.258 & 40 & 48 & 62 & 85 \\
\hline
\end{tabular}

Pode ser verificada a grande influência da taxa de aplicação no potencial de consumo de biossólido nos povoamentos de eucalipto no entorno da ETE de Barueri. Para uma mesma produção de biossólido na ETE, o aumento na dose de aplicação obviamente reduz o raio de consumo. Por exemplo, caso $25 \%$ da área apresentada na Tabela 16 esteja disponível, e para uma produção de $350 \mathrm{t} \mathrm{dia}^{-1}$ de biossólido, as distâncias que consumiriam a produção variam de $85 \mathrm{~km}$ para a dose de $30 \mathrm{t} \mathrm{ha}^{-1}$ até $178 \mathrm{~km}$ para a dose de $10 \mathrm{t} \mathrm{ha}^{-1}$.

Uma série de fatores pode influenciar a determinação da taxa de aplicação de biossólido mais adequado para povoamentos florestais. Dentre os principais podem ser destacados o teor de contaminantes no biossólido, as características do solo, as necessidades das culturas e os aspectos econômicos. Doses da ordem de $10 \mathrm{t} \mathrm{ha}^{-1}$ são relativamente baixas, quando considerados os valores encontrados na literatura (Tabela 14). No experimento avaliado por 
Andrade (1999) no Município de Itatinga (SP), por exemplo, foram utilizadas doses de biossólido de até $40 \mathrm{t} \mathrm{ha}^{-1}$ em Eucalyptus grandis. Este cenário representa condições pessimistas, e seria recomendado em situações onde as áreas reflorestadas apresentassem restrições ao uso do biossólido, como por exemplo alta permeabilidade e possibilidade de contaminação do lençol freático por nitratos. Já a utilização da maior dose de biossólido ( 30 t ha ${ }^{-1}$ ), só é possível em condições favoráveis. Por exemplo, quando o biossólido apresentar baixos teores dos contaminantes regulados pela norma da CETESB e a aplicação representar pequeno risco de impacto ao ambiente.

Ainda de acordo com os dados da Tabela 18, quando considerada a mesma taxa de aplicação, aumentos de produção de biossólido na ETE aumentam o raio de consumo. Por exemplo, se apenas $25 \%$ das áreas apresentadas na Tabela 16 estivessem disponíveis e para um nível de aplicação de $10 \mathrm{tha}^{-1}$, a produção anual de biossólido seria consumida em distâncias de 101, 147 e 178 km para as produções simuladas de 150, 250 e $350 \mathrm{t} \mathrm{dia}^{-1}$, respectivamente.

O nível de redução da área reflorestada potencialmente apta à disposição do biossólido, de acordo com a CETESB, depende de aspectos relacionados aos sítios de aplicação, por exemplo profundidade do lençol freático e declividade do terreno. Os percentuais de redução da área simulados refletem diferentes condições, desde muito favoráveis $(100 \%$ da área disponivel é apta) até muito desfavoráveis (onde apenas $25 \%$ da área disponível é apta). O mais provável é que algum percentual de redução da área efetivamente disponível deva ser considerado.

Devido à grande extensão de área considerada neste estudo para avaliação da demanda potencial de biossólido (raio de 200 quilômetros de Barueri), foi necessário considerar dados detalhados de inventário florestal do Estado de São Paulo. O trabalho mais recente, e que atende aos objetivos do trabalho, foi publicado em 1993 (Kronka et al., 1993). Entretanto, a análise da Figura 3 evidencia que a área reflorestada anualmente com eucalipto tem aumentado nos últimos anos. Tais considerações sugerem que o potencial de 
consumo do biossólido apresentado, apesar de promissor, pode ainda estar sub-estimado. Deve-se considerar também que as distâncias em relação à ETE de Barueri aqui apresentadas se referem a valores lineares. Os valores que efetivamente serão percorridos quando do transporte do biossólido serão maiores e dependem da rota das estradas que conduzem até as áreas de consumo. Outro aspecto a considerar é a posição relativa dos povoamentos florestais disponíveis para fertilização com o biossólido. Por exemplo, povoamentos que foram localizados linearmente em um mesmo raio podem apresentar distâncias efetivas de transporte bastante distintas.

\subsection{Custos da disposição de biossólido em povoamentos de eucalipto}

Os dados de custo de frete coletados no período de 25/04/1998 a 19/11/1999 apresentaram tendência de diminuição do valor com o aumento da distância de transporte (Figura 5).

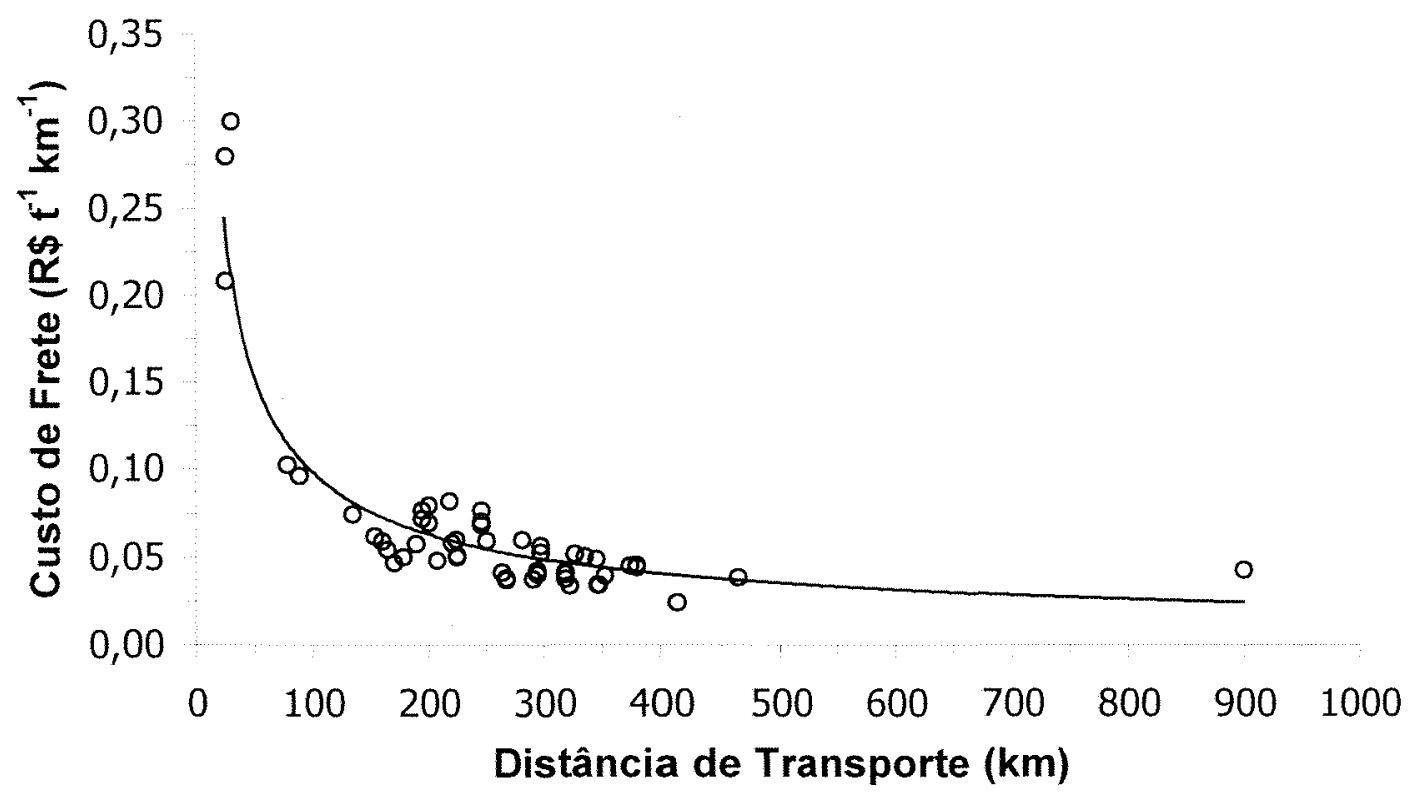

Figura 5 - Evolução do custo de frete para calcário à granel em função da distância de transporte. 
De acordo com as empresas de transporte rodoviário consultadas, via telefone, a redução do custo de frete é possível devido à maior diluição do custo fixo dos veículos quanto maior for a distância percorrida. Por outro lado, o custo de frete para distâncias menores também pode diminuir em função da possibilidade de se realizar um número maior de viagens. Segundo o periódico ${ }^{15}$ utilizado para coleta dos dados, não houve mudança significativa no valor do custo de frete ao longo do período considerado. Provavelmente, esse fato se deve à relativa estabilidade econômica atual e, segundo as transportadoras, ao aumento da concorrência no setor.

Os dados coletados foram plotados em um gráfico de custos de frete versus distância, indicando uma relação possivel de ajuste de acordo com o modelo $C F=a D^{b}$, onde $C F=$ custo do frete ida e volta $\left(R \$ t^{-1} k m^{-1}\right)$ e DT = distância de transporte $(\mathrm{km})$ (Figura 5 ). Os resultados da regressão são apresentados na Tabela 19, e revelam um bom ajuste. O coeficiente de determinação obtido foi de $87 \%$.

Tabela 19. Resultados estatísticos para o ajuste do modelo linearizado: custo de frete em função da distância de transporte.

\begin{tabular}{cccccc}
\hline \multicolumn{7}{c}{ Modelo linearizado: } & $\ln (\mathrm{CF})=\mathrm{a}+\mathrm{b} \ln (\mathrm{DT})$ \\
\hline Parâmetro & Coeficiente & Desvio Padrão & $\mathrm{T}$ & $\mathrm{P}$ \\
\hline $\mathrm{a}$ & 0,61265 & 0,09407 & 6,51 & $<0,001$ \\
$\mathrm{~b}$ & $-0,63681$ & 0,01826 & $-34,88$ & $<0,001$ \\
\hline \multicolumn{7}{c}{ ANOVA } & & \\
\hline Fonte de Variação & $\mathrm{GL}$ & $\mathrm{SQ}$ & $\mathrm{QM}$ & $\mathrm{F}$ & $\mathrm{P}$ \\
\hline Regressão & 1 & 78,018 & 78,018 & 1216,59 & $<0,001$ \\
Erro & 185 & 11,864 & 0,064 & & \\
Total & 186 & 89,882 & & & \\
\hline
\end{tabular}

Apesar do modelo ter apresentado um bom ajuste aos dados, deve-se considerar que o valor do custo de frete, além da distância de transporte, depende de outros fatores, como por exemplo o volume transportado, a

${ }^{15}$ Sistema de Informações de Fretes para Cargas Agrícolas (SIFRECA). 
periodicidade do transporte, características do produto, rota percorrida etc. No caso da ETE de Barueri a periodicidade de produção e o grande volume gerado podem ser aspectos favoráveis na negociação do custo de frete para o biossólido até o seu local de utilização. Por outro lado, se as características inerentes ao biossólido (teor de contaminantes, potencial corrosivo etc.) exigirem veículos especialmente adaptados, diferentes dos utilizados para o transporte de calcário à granel, os custos de frete poderão ser maiores.

O custo de distribuição do biossólido no campo utilizado neste trabalho foi de 4,00 reais por tonelada ${ }^{16}$, em base seca. O valor baseou-se no sugerido pela Companhia Suzano de Papel e Celulose para a distribuição de "composto de resíduos urbanos" utilizado comercialmente na fertilização de povoamentos de eucalipto dessa empresa.

Considerando os custos de transporte e distribuição e um teor seco do biossólido de $40 \%$, chega-se a seguinte expressão para cálculo do custo total da fertilização:

$$
F=\left(\frac{D S .100}{40}\right)\left(1,8453 D T^{0,3632}+4\right)
$$

em que:

$\mathrm{F}=$ Custo total da fertilização com o biossólido $\left(\mathrm{R} \$ \mathrm{ha} \mathrm{a}^{-1}\right)$;

DS = Dose de aplicação, em base seca $\left(t \mathrm{ha}^{-1}\right)$;

DT = Distância de Transporte $(\mathrm{km})$.

O comportamento do custo total da fertilização de eucaliptos com biossólido, por tonelada seca aplicada, em função da distância de transporte pode ser observado na (Figura 6). O incremento na variação do custo de total é maior em distâncias menores, refletindo o comportamento do modelo de custo de frete utilizado.

\footnotetext{
${ }^{16}$ Fonte: Companhia Suzano de Papel e Celulose: Núcleo Florestal 6 e 7. Telefone: (15) 981-9349 - Endereço eletrônico: drnf6@fb.suzano.com.br
} 


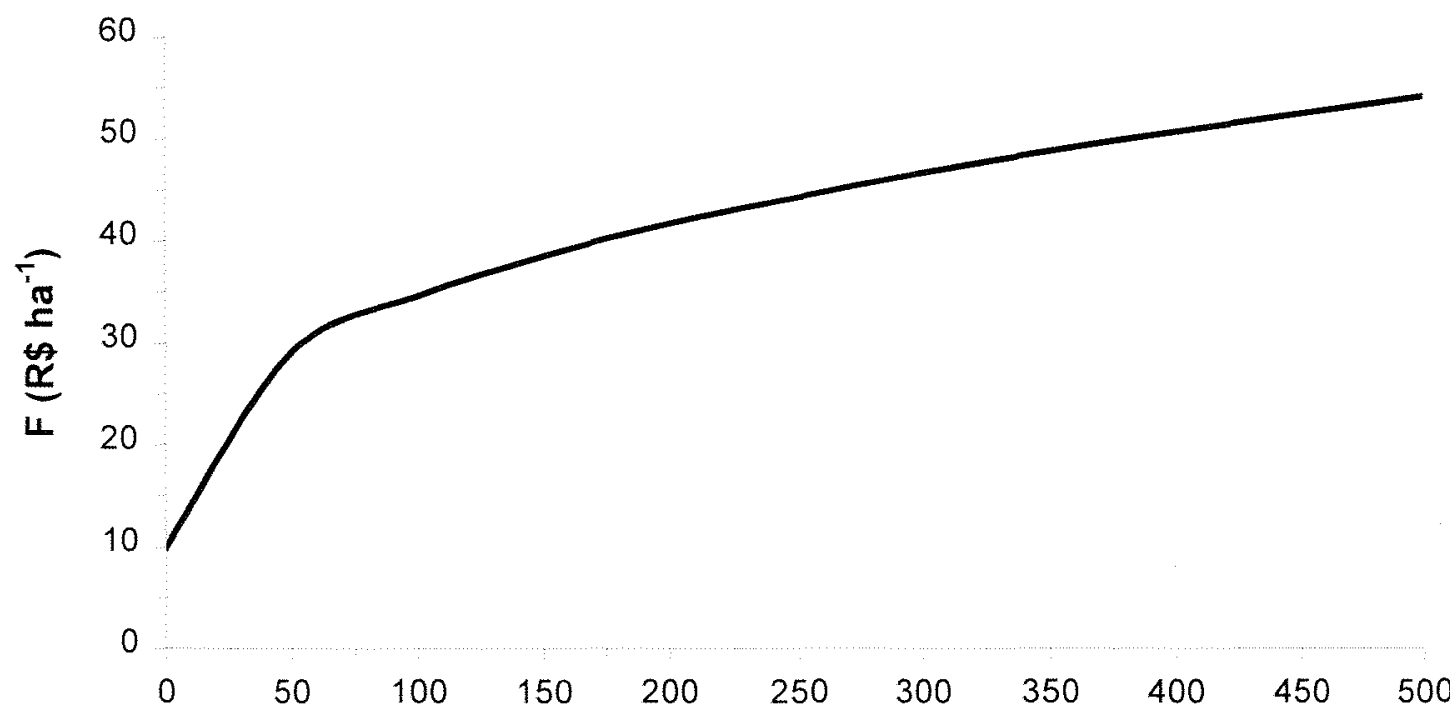

Distância de Transporte (km)

Figura 6 - Variação do custo total da fertilização de eucaliptos com biossólido, por tonelada seca aplicada, em função da distância de transporte, considerando teor de umidade de $60 \%$.

$\mathrm{F}=$ Custo Total da Fertilização.

\subsection{Nível Mínimo de Resposta (NMR) para aplicação do biossólido em povoamentos de eucalipto}

O NMR é um parâmetro que auxilia a determinar os limites econômicos da fertilização de florestas de eucaliptos com o biossólido. Ele representa o limiar da economicidade, isto é, para uma dada combinação de variáveis, ele representa o ganho mínimo de produtividade necessário para que essa alternativa de destinação do biossólido seja econômica. Outra utilidade desse tipo de simulação é a possibilidade de determinar distâncias economicamente viáveis de transporte do biossólido, considerando uma combinação de valores para as variáveis.

As Figuras 7, 8 e 9 apresentam os níveis mínimos de resposta (NMR), por tonelada seca aplicada, para a economicidade da fertilização de 
povoamentos de eucalipto com biossólido, considerando diferentes ciclos de produção e épocas de aplicação do biossólido.

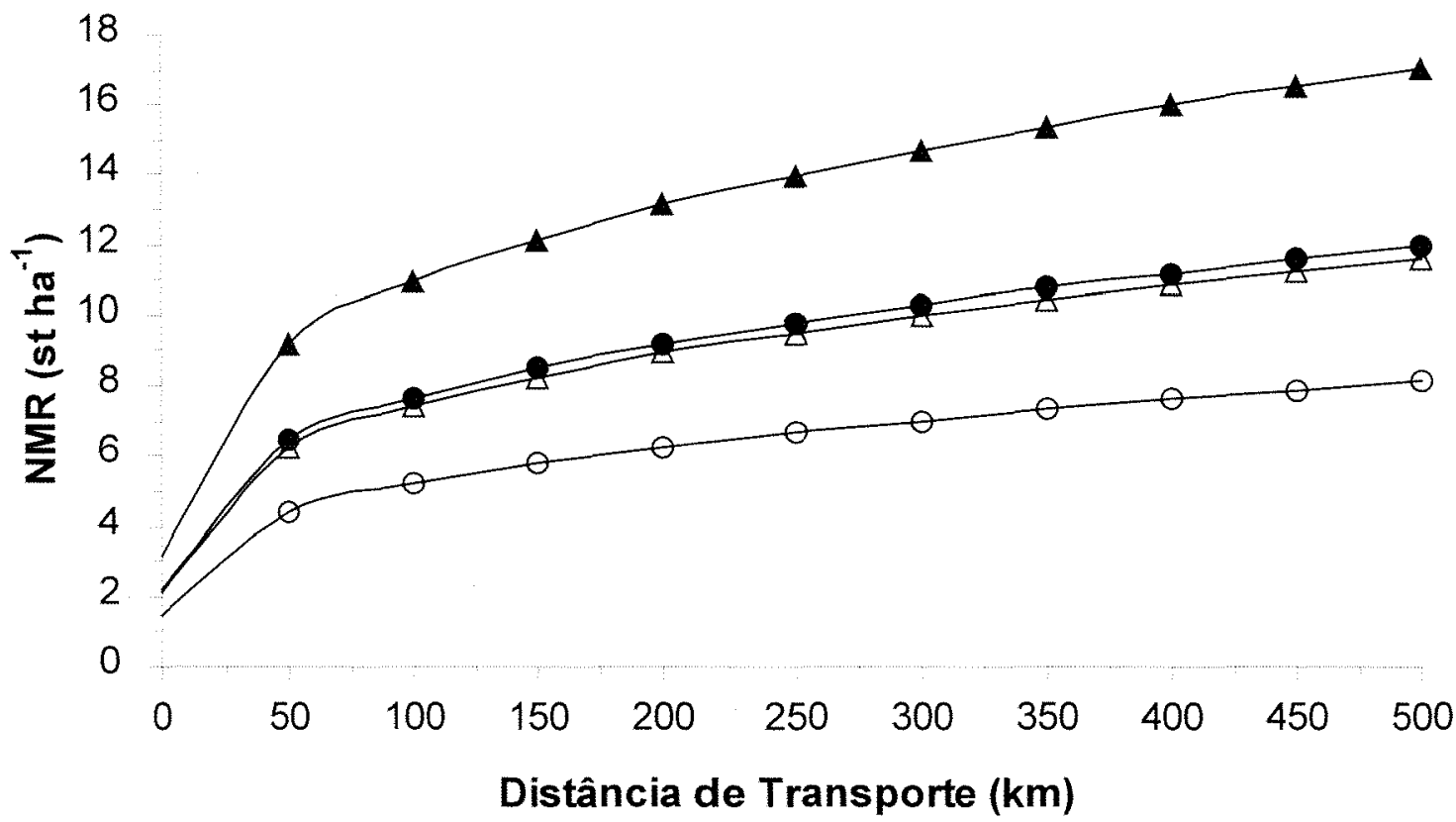

$$
\begin{array}{ll}
\triangle \mathrm{i}=6 \% \mathrm{p}=\mathrm{R} \$ 7,00 & -\mathrm{i}=6 \% \mathrm{p}=\mathrm{R} \$ 10,00 \\
\neg \mathrm{i}=12 \% \mathrm{p}=\mathrm{R} \$ 7,00 & -\mathrm{i}=12 \% \mathrm{p}=\mathrm{R} \$ 10,00
\end{array}
$$

Figura 7 - NMR por tonelada seca de biossólido aplicada em povoamentos de eucalipto em função da distância de transporte, da taxa de juros e do preço de madeira, considerando teor de umidade no biossólido de $60 \%$. É valido para o cenário de aplicação no plantio e ciclo de 7 anos e para a aplicação no plantio e reaplicação na condução da brotação com rotações de 7 anos.

Um comportamento verificado em todos os cenários é que quanto maior a distância de transporte, maiores devem ser os ganhos de produção para que essa alternativa de destinação final para o biossólido seja econômica. O incremento na variação é maior em distâncias menores, refletindo a tendência verificada na equação de custo de frete utilizada (Figura 5). 


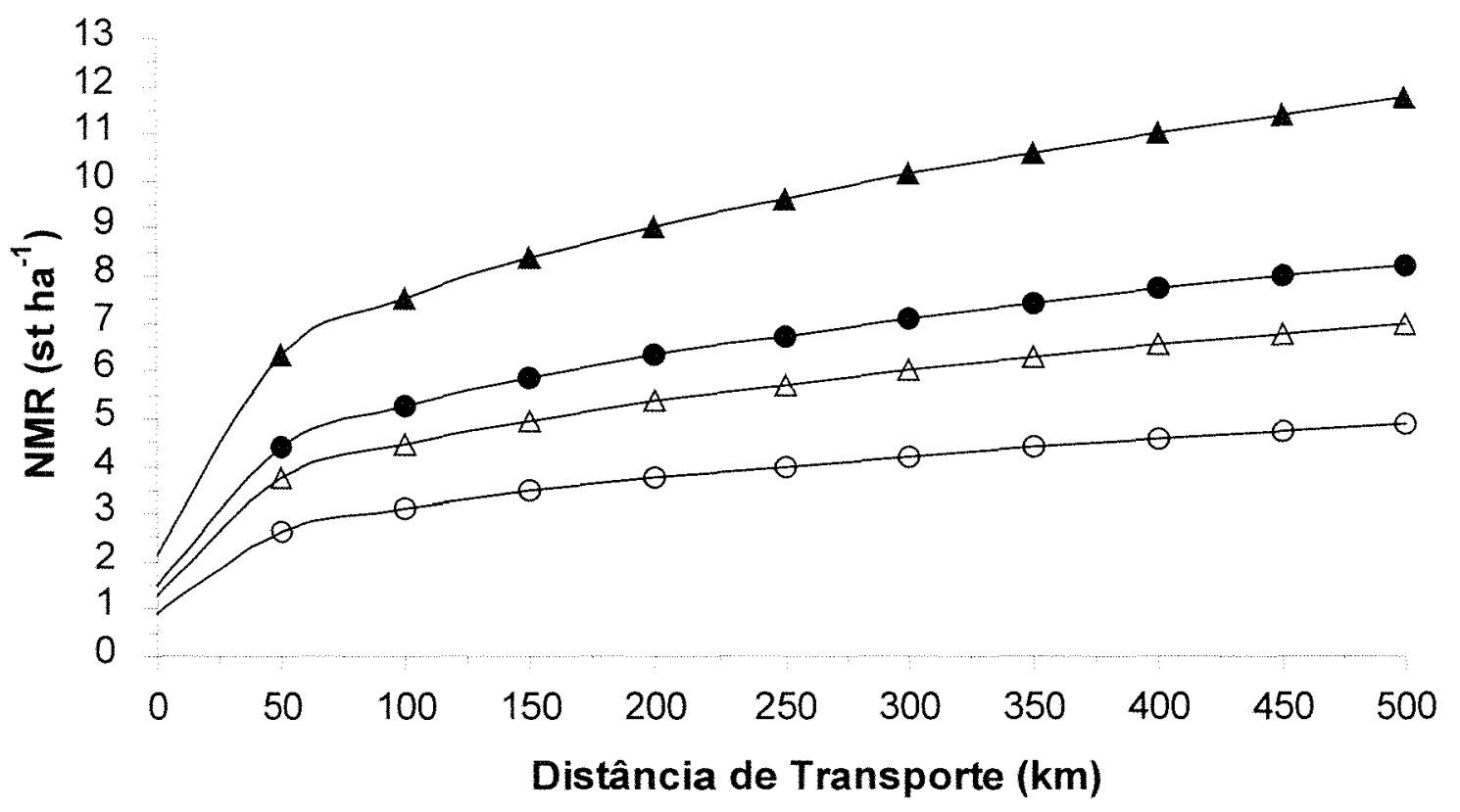

$$
\begin{array}{ll}
\triangle i=6 \% p=R \$ 7,00 & -i=6 \% p=R \$ 10,00 \\
\neg i=12 \% p=R \$ 7,00 & \rightarrow i=12 \% p=R \$ 10,00
\end{array}
$$

Figura 8 - NMR por tonelada seca de biossólido aplicada em função da distância de transporte, da taxa de juros e do preço de madeira, considerando teor de umidade no biossólido de $60 \%$. É valido para o cenário de aplicação apenas no plantio e ciclo de 14 anos com duas rotações de 7 anos.

O incremento no valor do NMR, por tonelada seca de biossólido aplicada, ocasionado pela variação da distância de 50 para $100 \mathrm{~km}$ é de $1,73 \mathrm{st} \mathrm{ha}^{-1}$, quando considerada a variação da distância de 450 para $500 \mathrm{~km}$ o incremento no NMR é de apenas 0,52 st ha $^{-1}$ (para aplicação do biossólido apenas no plantio, ciclo com uma rotação de 7 anos, taxa de juros de $12 \%$ e preço da madeira de $R \$ 7,00 \mathrm{st}^{-1}$ ). Esse comportamento foi verificado em todos os cenários, sendo mais acentuado quando o biossólido é reaplicado na condução da brotação (Figura 7).

Permanecendo os valores das outras variáveis constantes, os valores para o NMR aumentam com o aumento da taxa de juros, para todos os cenários avaliados. Como exemplo temos que o NMR, por tonelada de biossólido aplicada, para a distância de $200 \mathrm{~km}$ é de 9 e 13 st ha ${ }^{-1}$, para taxa de juros de 
6 e $12 \%$, respectivamente (com preço da madeira de $R \$ 7,00 \mathrm{st}^{-1}$, ciclo com uma rotação de 7 anos e aplicação apenas no plantio).

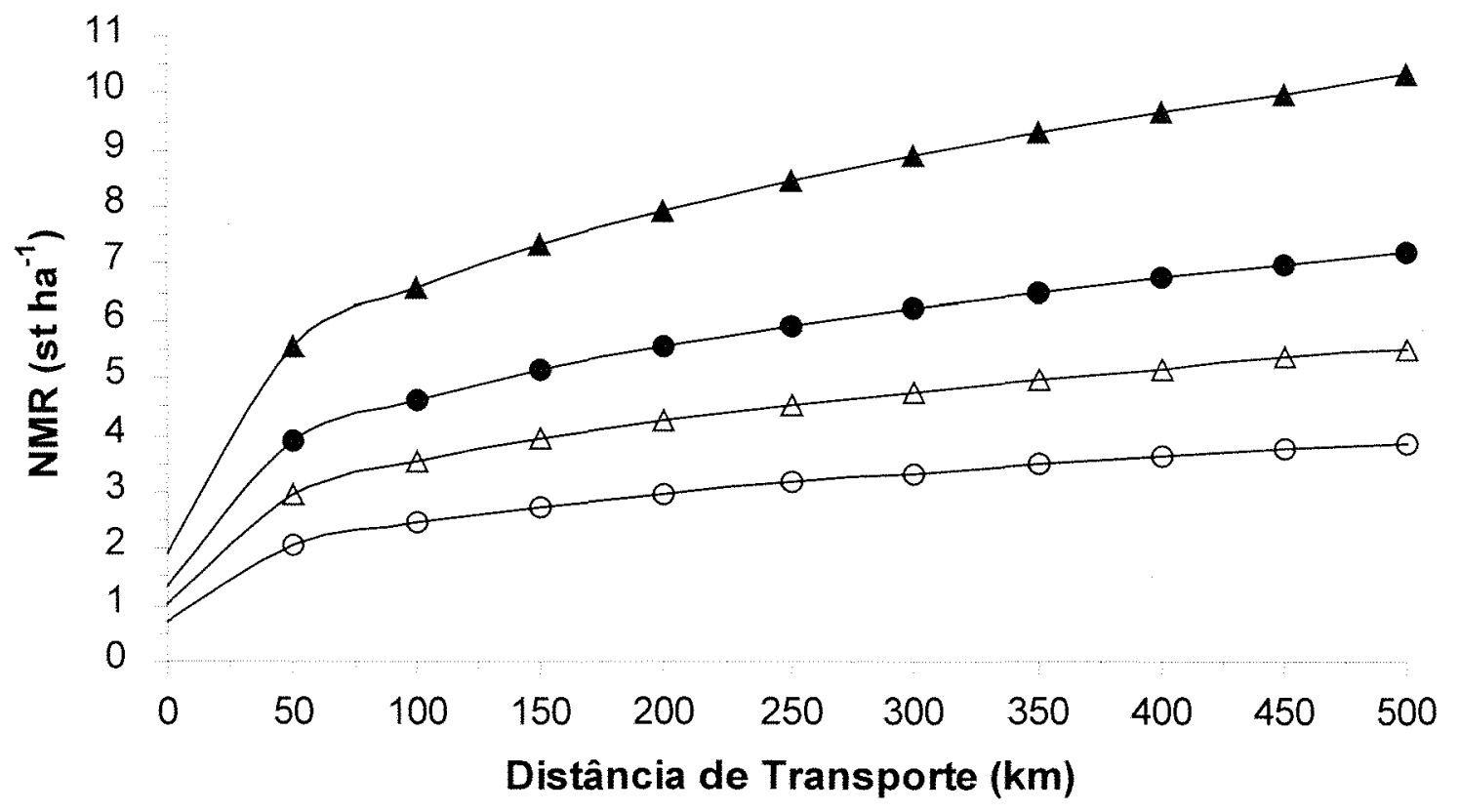

$$
\begin{aligned}
& \triangle i=6 \% p=R \$ 7,00 \\
& \longleftarrow i=12 \% p=R \$ 7,00
\end{aligned}
$$$$
\begin{aligned}
& \multimap i=6 \% p=R \$ 10,00 \\
& \multimap i=12 \% p=R \$ 10,00
\end{aligned}
$$

Figura 9 - NMR por tonelada seca de biossólido aplicada em função da distância de transporte, da taxa de juros e do preço de madeira, considerando teor de umidade no biossólido de $60 \%$. É valido para o cenário de aplicação apenas no plantio e ciclo de 21 anos com três rotações de 7 anos.

Esse comportamento pode ser explicado pelo fato da taxa de juros refletir uma expectativa de ganho ou retorno. Quanto maior essa expectativa maiores receitas são exigidas no futuro.

O preço de venda da madeira também influenciou de forma significativa os resultados financeiros, em todos os cenários avaliados. Quando se consideram maiores preços da madeira, permanecendo constantes os níveis das outras variáveis, menores ganhos de produtividade são exigidos. Os NMRs para a distância de $200 \mathrm{~km}$ são 13 e $9 \mathrm{st} \mathrm{ha}^{-1}$, para preço de madeira de $R \$ 7,00$ e $R \$ 10,00$ por estéreo, respectivamente (com taxa de juros de $12 \%$, 
aplicação do biossólido apenas no plantio e ciclo com uma rotação de 7 anos). No desenvolvimento das expressões foi considerada igualdade entre custos e receitas. Dessa forma, quanto maiores os custos maiores devem ser as fontes de receitas (volume de madeira que deve ser produzido) e vice-versa. Essa variação comprova que a expectativa de preço para a venda da madeira afeta significativamente a viabilização econômica da fertilização de florestas com biossólido. Quanto maiores os preços de venda da madeira, permanecendo constantes as outras variáveis, mais atraente se torna essa alternativa. É interessante notar que para o ciclo de produção de 7 anos, as combinações de $6 \%$ com $R \$ 7,00 \mathrm{st}^{-1}$, e $12 \%$ com $R \$ 10,00 \mathrm{st}^{-1}$, para taxa de juros e preço da madeira, respectivamente, resultam em valores de NMR semelhantes (Figura 7). Esse resultado sugere que é possível compensar altas taxas de juros com maiores preços para a venda da madeira e vice-versa.

Quando consideradas duas ou mais rotações por ciclo, os NMRs são menores para aplicação apenas no plantio do que quando ele é reaplicado na condução da brotação. Para ciclos de duas ou mais rotações, a reaplicação de biossólido na condução da brotação gera maiores custos do que a aplicação apenas no plantio. Como se exigem custos e receitas iguais, os NMRs são maiores.

Outro fator que influenciou de forma acentuada o NMR, e portanto o desempenho financeiro, é a dose de aplicação. Permanecendo os níveis das outras variáveis constantes, o NMR é diretamente proporcional às doses consideradas. A determinação de doses adequadas de fertilizantes, minerais ou orgânicos, varia de acordo com o critério utilizado. A dose que produz a máxima produção pode não ser a economicamente adequada, uma vez que para a determinação da dose economicamente ótima são considerados os custos e receitas com a fertilização e não somente a produção adicional de madeira. Somente se o custo da fertilização, fosse nulo (transporte e distribuição do biossólido no campo realizados pela empresa de saneamento, 
por exemplo) a dose de máxima produção de madeira seria igual a dose mais econômica.

De acordo com os valores das variáveis utilizadas neste trabalho, podem ser definidos cenários favoráveis e desfavoráveis, do ponto de vista econômico, para a viabilização da fertilização de eucaliptos com o biossólido. Para a definição desses cenários foi utilizada a distância de transporte de $178 \mathrm{~km}$. Esse valor se refere ao maior raio de consumo obtido no estudo da demanda potencial (Tabela 18)

Os cenários que representam condições mais favoráveis são os que apresentam baixas taxas de juros e altos preços de venda de madeira. Observando taxa de juros de $6 \%$, preço de madeira de $\mathrm{R} \$ 10,00 \mathrm{st}^{-1}$ e distância de transporte de $178 \mathrm{~km}$, os cenários que geram NMRs de 6,06; 3,64 e 2,88 st ha $^{-1}$ por tonelada seca aplicada são, respectivamente: (i) aplicação apenas no plantio e ciclo de 7 anos ou no plantio e reaplicação na condução da brotação, com rotações de 7 anos; (ii) aplicação apenas no plantio com duas rotações de 7 anos cada; e (iii) aplicação apenas no plantio com três rotações de 7 anos cada. Na fertilização orgânica de eucaliptos foram observados ganhos de produtividade ${ }^{17}$, por tonelada de resíduo aplicada e em relação a testemunha, de até 5,51 (aos 79 meses) e 6,65 st ha-1 (aos 4 anos) para Eucalyptus grandis, utilizando-se cinza de biomassa florestal e composto de residuos urbanos, respectivamente (Moro, 1994 e Zen et al., 1994). Apesar dos NMRs para o cenário favorável serem semelhantes aos ganhos de produtividade efetivamente obtidos com a fertilização de eucaliptos com os resíduos orgânicos, é pouco provável encontrar na prática taxas mínimas aceitáveis baixas (ex. 6\%) e preço de madeira alto (ex. $\mathrm{R} \$ 10,00 \mathrm{st}^{-1}$ ).

Cenários desfavoráveis economicamente à fertilização de eucaliptos com biossólido são aqueles que apresentam altas taxas de juros e baixos preços de venda de madeira. Para cenários com essas características e considerando os valores para as variáveis utilizados no presente estudo (taxa

\footnotetext{
${ }^{17}$ Considerando fator de conversão sugerido por $\operatorname{IPEF}\left(1 \mathrm{st}=0,70 \mathrm{~m}^{3}\right)$. Fonte: www.ipef.br.estatflorest/indtecnicos.html
} 
de juros de $12 \%$ e preço de madeira de $R \$ 7,00 \mathrm{st}^{-1}$ ) e a distância de transporte de $178 \mathrm{~km}$, foram obtidos NMRs, por tonelada seca de biossólido, de 12,$73 ; 8,76$ e 7,68 st $h^{-1}$, respectivamente para os seguintes cenários: (i) aplicação apenas no plantio e ciclo de 7 anos ou no plantio e reaplicação na condução da brotação, com rotações de 7 anos; (ii) aplicação apenas no plantio com duas rotações de 7 anos cada; e (iii) aplicação apenas no plantio com três rotações de 7 anos cada. Verifica-se neste caso, que os NMRs são maiores do que as produtividades efetivamente obtidas com a fertilização de eucaliptos com cinza de biomassa florestal e com o composto de resíduos urbanos.

O teor de umidade do biossólido afeta significativamente os custos da fertilização de eucaliptos, e, por conseqüência, a economicidade desta proposta de destinação. Para avaliar este efeito, pode ser simulada a redução do teor de umidade no biossólido de 60\% (teor médio atual) para 10\% (teor médio se o biossólido for seco termicamente, segundo Tsutya (2000)). Comparando-se os NMRs obtidos na simulação com os ganhos de produtividade obtidos na fertilização com cinza de biomassa florestal e com composto de resíduos urbanos, por exemplo, verifica-se a grande influência do teor de umidade nos custos da fertilização de eucaliptos com biossólido (Figura 10). Com um teor de umidade de $60 \%$, o raio econômico de uso da fertilização de povoamentos de eucaliptos com biossólido é bastante limitado, principalmente quando consideradas altas taxas de juros e baixos preços de madeira. A redução do teor de umidade para $10 \%$ aumentou consideravelmente a estimativa do raio econômico de uso. Entretanto, esse tipo de simulação assume que o custo total da fertilização é proporcional ao teor de umidade do biossólido. Quanto ao custo de frete, espera-se que essa relação seja verdadeira assumindo que o fator limitante ao transporte é a massa e não o volume do biossólido. Entretanto, quanto ao custo de distribuição a relação pode não apresentar tal proporcionalidade. 


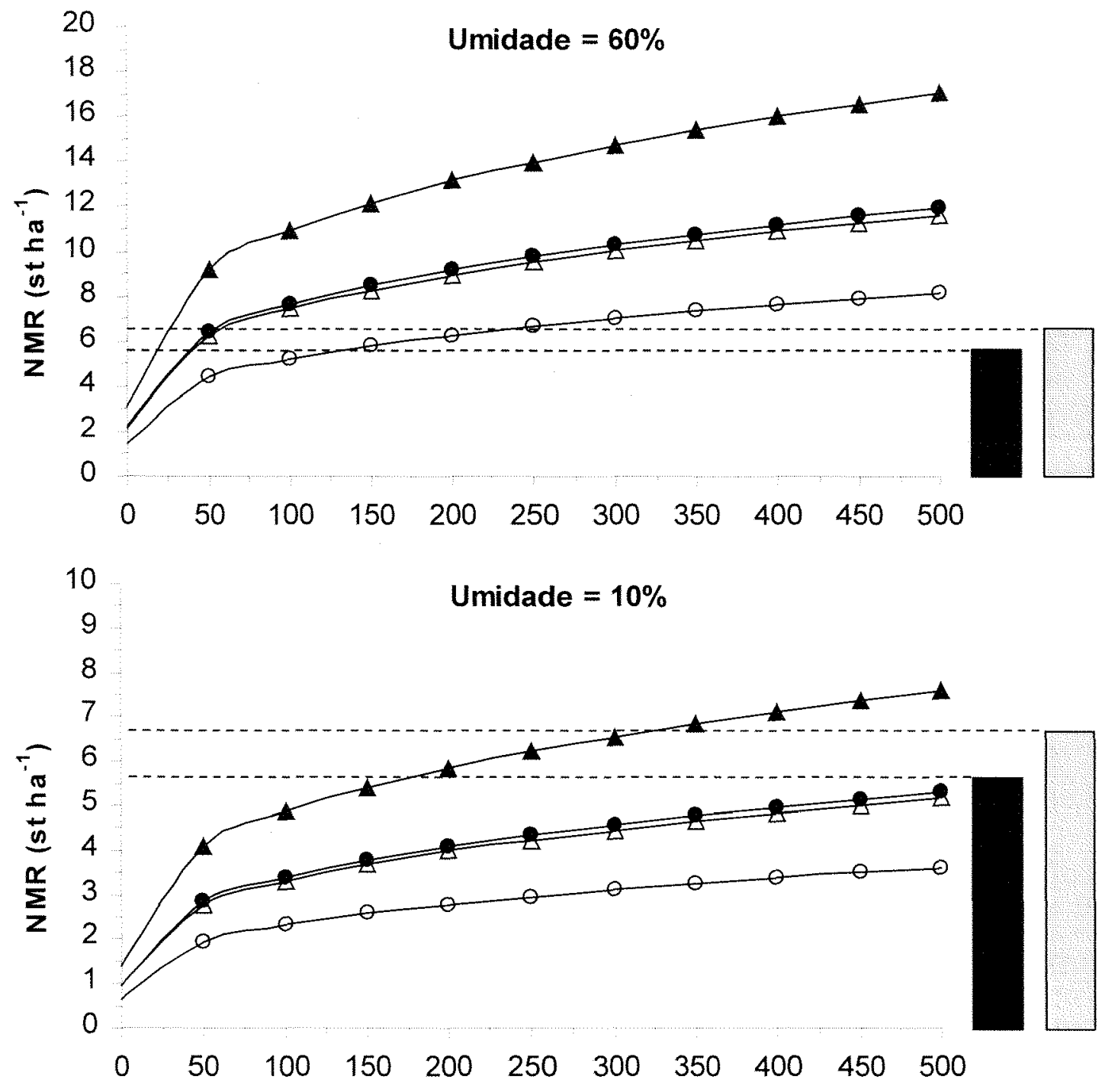

Distância de Transporte (km)

$$
\begin{array}{ll}
\triangle \mathrm{i}=6 \% \mathrm{p}=\mathrm{R} \$ 7,00 & -\mathrm{O}=6 \% \mathrm{p}=\mathrm{R} \$ 10,00 \\
\triangle \mathrm{i}=12 \% \mathrm{p}=\mathrm{R} \$ 7,00 & -\mathrm{i}=12 \% \mathrm{p}=\mathrm{R} \$ 10,00 \\
\mathrm{CBF} & \square \mathrm{CRU}
\end{array}
$$

Figura 10 - NMRs para dois teores de umidade no biossólido comparativamente aos ganhos de produtividade, por tonelada aplica e em relação a testemunha, da fertilização de Eucalyptus grandis com cinza de biomassa florestal (CBF) e composto de resíduos urbanos (CRU).

Fonte: Adaptado da Figura 7, Moro (1994) e Zen et al. (1994). 


\section{CONSIDERAÇÕES FINAIS E CONCLUSÕES}

$\mathrm{Na}$ revisão bibliográfica foram discutidas as principais alternativas para a destinação final do biossólido. Nessa parte do trabalho, evidenciou-se a tendência predominante atualmente de se implementar alternativas que priorizem a reciclagem desse resíduo, como seu uso como fertilizante orgânico, por exemplo.

Na seção 4.1 foi demonstrado que a demanda potencial de biossólido em povoamentos de eucalipto é grande. A produção do biossólido da ETE de Barueri seria consumida em um raio máximo de $178 \mathrm{Km}$ no seu entorno, quando considerada uma pequena dose de aplicação (10 t ha ${ }^{-1}$ ), elevada produção na ETE (350 t dia ${ }^{-1}$ ) e elevada redução percentual da área disponível para a fertilização $(75 \%)$.

O estudo econômico demonstrou que a fertilização de povoamentos de eucaliptos com biossólido contendo altos teores de umidade $(60 \%)$ pode apresentar limitações de ordem econômica. Mesmo nos cenários mais favoráveis (taxa mínima aceitável de retorno de $6 \%$ e preço de $\mathrm{R} \$ 10,00$ para a madeira), ganhos de produtividade acima de 5 st ha ${ }^{-1}$, por tonelada seca aplicada, seriam necessários para justificar a aplicação em distâncias longas de transporte $(\geq 100 \mathrm{~km}$ ) (Figura 7). Nos cenários mais desfavoráveis (taxa de $12 \%$ e preço da madeira de $R \$ 7,00$ ), a fertilização de florestas com biossólido foi limitada à situações que resultam em ganhos de produtividade de até 10,92 $\mathrm{st} \mathrm{ha}^{-1}$, por tonelada seca aplicada, em locais próximos $(\leq 100 \mathrm{~km}) \mathrm{da}$ ETE (Figura 7). Este valor é bastante elevado quando comparados aos obtidos na fertilização de eucaliptos com cinza de biomassa florestal e composto de resíduos urbanos (5,51 e 6,65 st ha ${ }^{-1}$, respectivamente). O principal fator para 
esse comportamento é o elevado custo com o transporte, devido principalmente à elevada taxa de umidade do biossólido (em média 60\%).

Consultando a literatura sobre o uso do biossólido como fertilizante é possível encontrar a advertência de diversos autores sobre a limitação das doses que podem ser utilizadas, devido a presença de contaminantes nesse residuo. Entretanto, os resultados deste trabalho nos apresenta outro limitante à utilização de elevadas doses de biossólido: o fator econômico. Não obstante das considerações realizadas para a análise apresentada nesse trabalho, é fácil imaginar, por analogia, que essa limitação deva ocorrer independentemente da cultura que se pretenda fertilizar. Juntamente com iniciativas para redução da umidade do biossólido, sistemas alternativos de transporte e distribuição mais eficientes poderiam reduzir o custo da fertilização e, consequentemente, poderse-ia esperar aumento no raio econômico para a fertilização de eucalipto com o biossólido.

No Brasil, a fertilização de povoamentos florestais com o biossólido ainda se encontra em fase inicial de pesquisas, e ainda carece de informações, especialmente no que se refere aos ganhos de produtividade das espécies e dos coeficientes técnicos das atividades envolvidas. Entretanto, os cenários simulados neste trabalho evidenciam que se o usuário do biossólido como fertilizante tiver que arcar com o custo total do transporte e aplicação, o raio econômico de uso provavelmente será bastante limitado. Isso pode inviabilizar a fertilização de florestas com o biossólido em escala comercial. Como forma de incentivo, deve-se avaliar a possibilidade da empresa geradora do biossólido arcar com parte dos custos do transporte e/ou da distribuição do biossólido nos sítios florestais. Em face às demandas das novas leis ambientais que atribuem ao gerador do resíduo a responsabilidade por seu destino final adequado, justifica-se a disseminação desse ônus na comunidade, tornando-a o partícipe na destinação de seus próprios residuos. A longo prazo o incentivo poderia ser economicamente vantajoso para as empresas geradoras de biossólido, quando considerados os custos de construção e manutenção dos aterros sanitários, forma predominante de disposição atualmente. Quando possível o incentivo ao 
uso do biossólido como fertilizante, a sua não destinação em aterros sanitários poderia ser plenamente viabilizada.

São conclusões deste trabalho:

1) Existem povoamentos de eucalipto no entorno de Barueri, suficientes para consumir toda a produção de biossólido dessa ETE, em distâncias de transporte economicamente viáveis, quando considerados cenários favoráveis financeiramente; e

2) Existem cenários que viabilizariam o uso do biossólido em povoamentos de eucalipto, dentro de intervalos realísticos de taxas de juros e preços de madeira, o que justifica estudos mais detalhados dessa alternativa de destinação final para o biossólido, em termos silviculturais e ecológicos. 


\section{REFERÊNCIAS BIBLIOGRÁFICAS}

ALEN SOBRINHO, P. Tratamento de esgoto e geração de lodo. In: BETTIOL, W.; CAMARGO, O.A. (Ed.) Impacto ambiental do uso agrícola do lodo de esgoto. Jaguariúna, SP: EMBRAPA Meio Ambiente, 2000. p.11-24.

ANDRADE, C.A. de Nitratos e metais pesados no solo e em plantas de Eucalyptus grandis após aplicação de biossólido da ETE de Barueri. Piracicaba, 1999. 65p. Dissertação (Mestrado) - Escola Superior de Agricultura "Luiz de Queiroz", Universidade de São Paulo.

ANDREOLI, C.V.; LARA, A.L.; FERNANDES, F. Reciclagem de biossólidos: transformando problemas em soluções. Curitiba: SANEPAR; Finep, 1999. 288p.

ANDREOLI, C.V.; PERGORINI, E.S. Gestão de Biossólidos: Situação e Perspectivas. In: SEMINÁRIO SOBRE GERENCIAMENTO DE BIOSSÓLIDOS DO MERCOSUL, 1., Curitiba, 1998. Anais. Curitiba: SANEPAR; ABES, 1998. p.11-18.

ASSOCIAÇÃO BRASILEIRA DE CELULOSE E PAPEL. Statistical Forest Report. São Paulo: BRACELPA, 1998. 60p.

ASSOCIAÇÃO BRASILEIRA DE NORMAS TÉCNICAS. Fórum nacional de normatização: NBR 11.175 Incineração de resíduos sólidos perigosos - Padrão de desempenho. Rio de Janeiro, 1990. ?p.

ASSOCIAÇÃO BRASILEIRA DE NORMAS TÉCNICAS. Fórum nacional de normatização: NBR 10.004 Resíduos sólidos. Rio de Janeiro, 1987.63p.

AYUSO, M.; PASCUAL, J.A.; GARCÍA, C. et al. Evaluation of urban wastes for agricultural use. Soil Science Plant Nutrition., v.42, n.1, p.105-111, 1996.

BERGER, R. Métodos para determinação da quantidade econômica de adubo para plantios de eucaliptos. Boletim Informativo IPEF, v.3, n.9., p.14-16, fev. 1975. 
BETTIOL, W.; CARVALHO, P.C.T.; FRANCO, B.J.D.C. Utilização do lodo de esgoto como fertilizante. O Solo, v.75, n.1, p.44-54, jan./jun. 1983.

BIDONE, F.R.A. Alternativas de Disposição Final de Biossólidos: Aterros, Landfarming e Incineração. In: SEMINÁRIO SOBRE GERENCIAMENTO DE BIOSSÓLIDOS DO MERCOSUL, 1., Curitiba, 1998. Anais. Curitiba: SANEPAR; ABES, 1998. p.131-135.

BRASIL. Ministério da Saúde. Centro de Vigilância Sanitária. Portaria nº 36, de 19 de Janeiro de 1990. Aprova normas e padrão de potabilidade de água destinada ao consumo humano. Diário Oficial da União, Brasília, 23 de Janeiro 1990. Seção 1, pt.1.

BRENNAN, M.J. The presence of radionuclides in sewage sludge and their effect on human health. Washington: Washington State Department of Healt. Environmental Radiation Program. WDOH/320-013, December, 1997. 16p.

BROCKWAY, D.G. Forest floor, soil, and vegetation responses to sludge fertilization in red and white pine plantations. Soil Science Society of America Journal, n.47, v.3, p.776-784, 1983.

BROCKWAY, D.G.; URIE, D.H. Determining sludge fertilization rates for forests from nitrate- $N$ in leachate and groundwater. Journal of Environmental Quality, v.12, n.4, p.487-492, 1983.

CAMPOS, J.R. Alternativas para tratamento de esgotos - pré tratamento de águas para abastecimento. Americana: Consórcio Intermunicipal das Bacias dos Rios Piracicaba e Capivari, 1994. 112p.

CLUTTER, J.L.; FORTSON, J.C.; PIENAAR, L.V. et al. Timber Management: a quantitative approach. New York: John Wiley, 1983. 329p.

COMPANHIA DE SANEAMENTO BÁSICO DO ESTADO DE SÃO PAULO. Qualidade do lodo das ETEs da RMSP. São Paulo: SABESP, 1996. 120p. (Relatório Técnico)

COMPANHIA DE SANEAMENTO BÁSICO DO PARANÁ. Manual técnico para a utilização do lodo de esgoto no Paraná. Curitiba: SANEPAR, 1997. 96p.

COMPANHIA DE TECNOLOGIA DE SANEAMENTO AMBIENTAL. Manual Técnico P 4.230 jan./99. Aplicação de biossólidos de sistemas de tratamento biológico em áreas agrícolas - Critérios para projeto e operação. São Paulo, CETESB, 1999. 33p. 
COMPANHIA DE TECNOLOGIA DE SANEAMENTO AMBIENTAL. Resultado de análises sobre a caracterização microbiológica e química de fertilizante organo-mineral - IPT/CETESB - Proposta 202256, 4p., s.d.

DEPARTAMENTO DE LIMPEZA URBANA DE SÃO PAULO. Situação da cidade de São Paulo em relação aos aterros sanitários: Aterros Sanitários em operação. s.d.

http://www.prodam.sp.gov.br/limpurb/probsol/des_as_situasp.htm (25 ago. 2000)

DEUS, A.B. de; CASTRO, C.M.B. de ; LUCA, S.J. A disposição de Lodos de esgoto no solo. In: SIMPÓSIO INTERNACIONAL DE QUALIDADE AMBIENTAL. Anais. Rio Grande do Sul: 1996. p.191-195.

DUTCH, J.; WOLSTENHOLME, R.; BENGTSSON, J. et al. The effects of sewage sludge application to a heathland site prior to planting with Sitka spruce. Ameliorative practices for restoring and maintaining long-term productivity in forests. Forest Ecology Management, v.1/3, n.66, p.151-163, 1994.

ENDO, H.; NAGAYOSHI, Y.; SUZUKI, K. Production of glass ceramics from sewage sludge. Water Science and Technology, v.36, n.11, p.235-241. 1997.

ESTADOS UNIDOS. Environmental Protection Agency. Standards for use or disposal of sewage sludge: 40 CFR Parts 403 and 503. Washington, 1995. 25p.

ESTADOS UNIDOS. Environmental Protection Agency. Sludge incineration: problems and remedies. Washington, 1986. ?p.

FERREIRA, J.M. Análise econômica preliminar da adubação mineral de eucalipto. In: SIMPÓSIO SOBRE ENERGIA DA BIOMASSA FLORESTAL, CONVÊNIO CESP/IPEF, São Paulo, 1983. Relatório final. São Paulo: CESP, p.241-253. 1983.

GIBBS, R.A.; HU, C.J.; HO, G.E. et al. Regrowth of fecal coliforms and Salmonellae in stored biosolids on soil amended with biosolids. Water Science and Technology, v.35, n.11-12, p.269-275, 1997.

GOMES, F.P.; GARCIA, C.H. A interpretação econômica de um ensaio de adubação de Eucalyptus grandis. Série Técnica IPEF, n.43/44, p.61-64, 1990. 
GONÇALVES, J.L. M.; RAIJ, B van.; GONÇALVES, J.C. Florestas. In: RAIJ, B. van; CANTARELA, H.; QUAGGIO, J.A.; FURLANI, A.M.C. de (Ed.) Recomendação de adubação e calagem para o Estado de São Paulo, 2. ed. Campinas: Instituto Agronômico \& Fundação IAC, 1996. p.247-259. (Boletim Técnico 100)

GRADECKAS, A.; KUBERTAVICIENE, L.; GRADECKAS, A. Utilization of wastewater sludge as a fertilizer in short rotation forests on cut away peatlands. Baltic Forestry, v.2, n.4, , p.7-13, 1998.

HALL, E.J. Standardizing and the management of biosolids: the international experience. In: SEMINÁRIO SOBRE GERENCIAMENTO DE BIOSSÓLIDOS DO MERCOSUL, 1., Curitiba, 1998. Anais. Curitiba: SANEPAR;ABES, 1998. p.113-22.

HARRISON, E.Z.; MCBRIDE, M.B.; BOULDIN, D.R. The case for caution: Recommendations for land application of sewage sludge and na appraisal of the US EPA's part 503 sludges rules. Cornell Wast Management Institute working paper. 40p. Agosto, 1997, revisado Fevereiro 1999. http://www.cfe.cornel.edu/wmi/PDFS/LandApp.pdf. (05 fev. de 2000)

HARRISON, R.B.; HENRY, C.L.; COLE, D.W. et al. Recycling of industrial wastes and forest harvesting residues on forest lands. In: SIMPÓSIO BRASILEIRO DE PESQUISA FLORESTAL, 1., Belo Horizonte, 1993. Anais. Belo Horizonte: SIF, 1993, p.255-264.

HARRISON, R.B.; REIS, M.G.F.; REIS, G.F. et al. Closing the loop: the rule of harvesting and transportation in maintaining productivity and returning organic waste to the forest. In: SEMINÁRIO DE ATUALIZAÇÃO SOBRE SISTEMAS DE COLHEITA DE MADEIRA E TRANSPORTE FLORESTAL, 9., 1996. p.101-118.

HENRY C.L.; COLE D.W.; HINCKLEY, T.M.; et al. The use of municipal and pulp and paper sludges to increase production in forestry. Journal of Sustainable Forestry, v.1, n.3, p. 41-55, 1993.

HENRY, C.L.; COLE, D.W.; HARRISON, R.B. et al. Use of municipal sludge to restore an improve site productivity in forestry: the Pack Forest Sludge Research Program. Forest Ecology Management, v.66, n.1/3, p.137-149, 1994.

INSTITUTO DE PESQUISAS E ESTUDOS FLORESTAIS, spectos econômicos da fertilização fosfatada em eucalipto. Circular Técnica IPEF, v.14, p.1-6, abr. 1976. 
KARABOLAD, J.C.; FERRETTI, M.R.J.; PEREIRA, M. de B. et al. Aterro Exclusivo para Lodo/Biossólido de ETEs: Alternativa para Disposição Final. In: SEMINÁRIO SOBRE GERENCIAMENTO DE BIOSSÓLIDOS DO MERCOSUL, 1., Curitiba, 1998. Anais. Curitiba: SANEPAR;ABES, 1998. p. 137-143.

KENPTON, T.J.; CUSACK, E. Sustainable management of BNR biosolids. Water Science and Technology, v.39, n.6, p.159-166. 1999.

KIEHL, E.J. Fertilizantes orgânicos. São Paulo: Ceres, 1985. 492p.

KING, L.D. Soil heavy metals. In: ALVAREZ V., V.H.; FONTES, L.E.F.; FONTES, M.P.F. (Ed.) O solo nos grandes domínios morfoclimáticos do Brasil e o desenvolvimento sustentado. Viçosa: SBCS; UFV; DPS, 1996. p.823-836,

KLEMPERER, W.D. Forest resource economics and finance. New York: Mcgraw Hill., 537p., 1996.

KRONKA, F.N.J.; MATSUKUMA, C.K.; NALON, M.A. et al. Inventário florestal do Estado de São de Paulo. São Paulo: SMA;CINP;IF, 199p., 1993. (Escala 1:250.000).

LUDUVICE, M. Gestão de Biossólidos e o Mercosul. In: SEMINÁRIO SOBRE GERENCIAMENTO DE BIOSSÓLIDOS DO MERCOSUL, 1., Curitiba, 1998. Anais. Curitiba: SANEPAR;ABES, 1998. p.9-10.

LUTRICK, M.C.; RIEKERK, H.; CORNELL, J.A. Soil and slash pine response to sludge applications in Florida. Soil Science Society of America Journal, v.2, n.50, p.447-451, 1986.

MATTHEWS, P. Sustainability in biosolids management. Water Science and Technology, v.38, n.2. p.97-102, 1998.

MCFADDEN, G.; SHIESS, P. Spray-distribution pattern from a prototype sludgeapplication vehicle under varying stand conditions. Forest Ecology Management., n.29, p.213-219, 1989.

MCNAB, W.H.; BERRY, C.R. Distribution of aboveground biomass in three pine species planted on a devastated site amended with sewage sludge or inorganic fertilizer. Forest Science, v.2, n.31, p.373-382, 1985.

MEDALIE L.; BOWDEN, W.B.; SMITH, C.T. Nutrient leaching following land application of aerobically digested municipal sewage sludge in a northern hardwood forest. Journal of Environmental Quality, v.23, n.1, p.130-138, 1994. 
MIEGROET, H. VAN; BOSTON, H.L.; JOHNSON, D.W. Environmental and plant effects of sewage sludge application to forests and pastures. Proceedings: Annual Madison Waste Conference, v.35, n.12, p.329-352, 1989.

MIKI, K.M. Utilização de polímeros para condicionamento de lodo de ETE para desidratação em filtro prensa de placas. São Paulo, 1998, v.1. 181p. Dissertação (Mestrado) - Escola Politécnica, Universidade de São Paulo.

MINISTÉRIO DO PLANEJAMENTO, ORÇAMENTO E GESTÃO. Investimentos e Ação Governamental, s.d.

http://www.planejamento.gov.br/planejamento/mp/ppa/mp/ppa_1996_1999 /investimentos.htm (25 ago. de 2000)

MONNEY, L. Beneficial use program for New York city's sludge. BioCycle, v.22, n.8, p.72-73, Aug. 1992.

MORO, M. Caracterização, distribuição e análise econômica dos resíduos industriais da Champion Papel e Celulose Ltda. In: SEMINÁRIO SOBRE O USO DE RESÍDUOS INDUSTRIAIS E URBANOS EM FLORESTAS, Botucatu, 1994. Anais. Botucatu: UNESP/FCA, 1994. p.155-66

NICKELSON, S.A.; WEST S.D. Renal cadmium concentrations in mice and shrews collected from forest lands treated with biosolids. Journal of Environmental Quality. v.25, n.1, p.86-91, 1996.

OLIVEIRA, C.O. Metais pesados e formas nitrogenadas em solos tratados com lodo de esgoto. Piracicaba, 1995. 90p. Dissertação (Mestrado) - Escola Superior de Agricultura "Luiz de Queiroz", Universidade de São Paulo.

ORGANIZAÇÃO MUNDIAL DA SAÚDE. Guidelines for the safe use of wastewater and excreta in agriculture and aquaculture: Measures for public health protection. Executive Summary. 20p. s.d. http://www.who.org/environmental_information/Information_resources/doc uments/wastreus.pdf (08 fev. de 2000)

PHILLIPS, R.; FISHER, J.T.; MEXAL, J.G. Fuelwood production utilizing Pinus eldarica and sewage sludge fertilizer. Forest Ecology Management, $\vee .16$, n. $1 / 4$, p.95-102, 1986.

POGGIANI, F.; BENEDETTI, V. Aplicabilidade do lodo filtrado de esgoto produzido na Região Metropolitana de São Paulo em plantações florestais de rápido crescimento. Piracicaba: ESALQ; Departamento de Ciências Florestais;IPEF;SABESP, 2000. 111p. (Relatório final) 
POLGLASE, P.J.; MYERS, B.J. Tree Plantations for Recycling Effluent and Biosolids in Australia. In: Environmental Management: the Role Of Eucalyptus and Other Fast Growing Species, Australia, Oct. 1995. Proceedings: Australia, 1995. p.100-109.

PRIMAVESI, A. Manejo ecológico do solo: a agricultura em regiões tropicais. São Paulo: Nobel, 1979. 549p.

RAIJ, B. van Uso agrícola de biossólidos. In: SEMINÁRIO SOBRE GERENCIAMENTO DE BIOSSÓLIDOS DO MERCOSUL, 1., Curitiba, 1998. Anais. Curitiba: SANEPAR;ABES, 1998. p.147-151.

REEVES, S.J.; PLIMER, I.R.; FOSTER, D. Exploitation of gold in a historic sewage sludge stockpile, Werribee, Australia: resource evaluation, chemical extraction and subsequent utilization of sludge. Journal of Geochemical Exploration, v.65, n.2, p.141-153, 1999.

RIDDELL BLACK, D.; PULFORD, I.D.; STEWART, C. Clonal variation in heavy metal uptake by willow. Biomass and energy crops. Aspects of Applied Biology, n.49, p.327-334, 1997.

ROCHA, M.T. Utilização de lodo de esgoto na agricultura: um estudo de caso para as bacias hidrográficas dos rios Piracicaba, Capivari e Jundiaí. Piracicaba, 1998. 140p. Dissertação (Mestrado) - Escola Superior de Agricultura "Luiz de Queiroz", Universidade de São Paulo.

RODELLA, A.A.; ALCARDE, J.C. Requisitos de qualidade física e química de fertilizantes minerais. In: GONÇALVES, 3.L. M.; BENEDETTI, V. (Ed.) Nutrição e fertilização florestal. Piracicaba: IPEF, 2000. cap.2, p.59-78.

RODRIGUEZ, L.C.E.; BATISTA, J.L.F.; COUTO, H.T.Z. do. I Programa de Reciclagem em Métodos Quantitativos. Curso V: Matemática Financeira na Gestão Florestal. Piracicaba: Departamento de Ciências Florestais, ESALQ, USP, 1996. 1v.

ROY, M.; COUILLARD, D. Metal leaching following sludge application to a deciduous forest soil. Water Research Oxford, v.5, n.32, p.1642-1652, 1998.

RUSSELL, A.I.; YUHSIA, B. Beneficial use of biosolids: progress in controlling metals. Water Science and Technology, v. 34, n. 3-4, p.493-497, 1996.

SANTOS, H.F. dos; TSUTYA, M.T. Aproveitamento e disposição final do lodo de esgoto de estações de tratamento do Estado de São Paulo. Engenharia Sanitária e Ambiental, v.2, n.2, p.70-81, Abr/Jun. 1997. 
SCCOL, V.T. Apectos sanitários do lodo de esgoto. In: SEMINÁRIO SOBRE GERENCIAMENTO DE BIOSSÓLIDOS DO MERCOSUL, 1., Curitiba, 1998. Anais. Curitiba: SANEPAR;ABES, 1998. p. 65-72.

TSUTYA, M.T. Alternativas de disposição final de biossólidos gerados em estações de tratamento de esgotos. In: BETTIOL, W.; CAMARGO, O.A. (Ed.) Impacto ambiental do uso agrícola do lodo de esgoto. Jaguariúna: EMBRAPA Meio Ambiente, 2000. cap.4, p.69-105.

WANG, MIN-JIAN Land application of sewage in China. The Science of the Total Environment, v.197, n.1-3, p. 149-160, 1997.

ZABOWSKI, D.; HENRY, C.L. Soil and foliar nitrogen after fertiliser treatment of ponderosa pine. Understanding plant nutrient supply - opportunities for managing site productivity. New Zealand Journal of Forestry Science, v.24, n.2-3, p.333-343, 1994.

ZEN, S.; BELLOTE, A.F.J.; SILVA, H.D. da; et al. Resíduos urbanos como fonte de nutrientes em povoamentos de eucalipto. In: SEMINÁRIO SOBRE O USO DE RESÍDUOS INDUSTRIAIS E URBANOS EM FLORESTAS, Botucatu, 1994. Anais. Botucatu: UNESP/FCA, 1994. p.25-39 
ANEXO 
Posição relativa dos municípios que compõem a Região Metropolitana de São Paulo (RMSP)

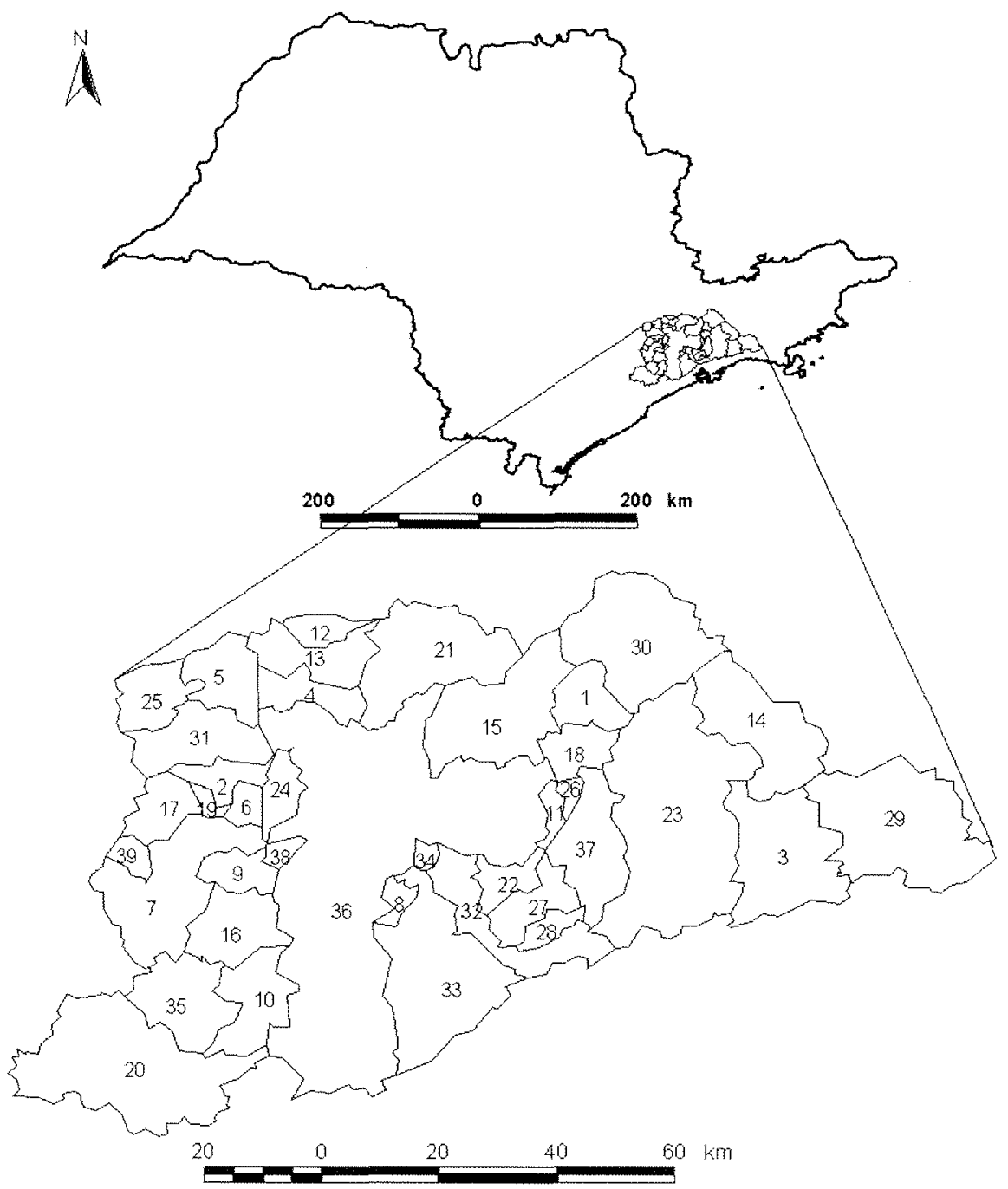

\section{LEGENDA:}

1. Arujá

5. Cajamar

9. Embú

13. Franco da Rocha

17. Itapeví

21. Mairiporã

25. Pirapora do Bom Jesus

29. Salesópolis

33. S. Bernardo do Campo

37. Suzano
2. Barueri

6. Carapicuíba

10. Embú Guaçu

14. Guaracema

18. Itaquatecetuba

22. Mauá

26. Poá

30. Santa Izabel

34. S. Caetano do Sul

38. Taboão da Serra
3. Biritiba Mirim

7. Cotia

11. Ferraz Vasconcelos

15. Guarulhos

19. Jandira

23. Mogi das Cruzes

27. Ribeirão Pires

31. Santana de Parnaíba

35. S. Lourenço da Serra

39. Vargem Grande Paulista
4. Caieiras

8. Diadema

12. Francisco Morato

16. Itapecirica da Serra

20. Juquitiba

24. Osasco

28. Rio Grande da Serra

32. Santo André

36. São Paulo 